\title{
Diversity and palaeoecology of Early Devonian invertebrate associations in the Tafilalt (Anti-Atlas, Morocco)
}

\author{
LINDA FREY, CAROLE NAGLIK, RICHARD HOFMANN, MENA SCHEMM-GREGORY, JIŘí FRÝDA, \\ BJÖRN KRÖGER, PAUL D. TAYLOR, MARK A. WILSON \& CHRISTIAN KLUG
}

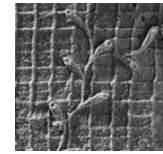

\begin{abstract}
Quantitative analyses of the taxonomic composition and palaeoecology of five Early Devonian faunules (earliest Lochkovian to early Emsian) collected from the locality Jebel Ouaoufilal in the Tafilalt (Morocco) were conducted. We examined 3376 specimens belonging to 158 species and their stratigraphic distribution. The quantitative data sets were analysed for alpha diversity and ecospace utilization. Macrofossils of every faunule were identified, counted and grouped according to ecological categories of tiering, motility and feeding behaviour. Based on these data, we noted (i) a strong increase in species richness, especially in benthic species, from the lowermost Lochkovian to the Pragian stage and a following subtle decrease in the early Emsian and (ii) a considerable expansion of ecospace use from the earliest Lochkovian to the early Emsian. These general trends are considered to be a result of favourable living conditions due to a growing oxygen content at the sea floor, which correlates with a regional and potentially a global regression from the Lochkovian to the Pragian. A transgression in the early Zlíchovian probably reduced the species richness by decreasing the oxygenation of bottom waters. Additionally, we described and figured three new genera and six new species of the diverse Pragian faunule (86 species): the hederelloid Filihernodia buccina gen. et sp. nov., the crinoid Hexawacrinus claudiakurtae gen. et sp. nov., the gastropods Oriomphalus multiornatus sp. nov., Eohormotomina restisevoluta gen. et sp. nov., and the cephalopods Tenuitheoceras secretum gen. et sp. nov. and Arionoceras kennethdebaetsi sp. nov. We record the first occurrence of Tiaracrinus moravicus from Africa. $\bullet$ Key words: Early Devonian, alpha diversity, palaeoecology, Cephalopoda, Gastropoda, Anti-Atlas, Morocco.
\end{abstract}

Frey, L., NAGlik, C., Hofmann, R., Schemm-Gregory, M., FrÝdA, J., KröGER, B., TAYlor, P.D., Wilson, M.A. \& KLUG, C. 2014. Diversity and palaeoecology of Early Devonian invertebrate associations in the Tafilalt (Anti-Atlas, Morocco). Bulletin of Geoscience 89(1), 75-112 (12 figures, appendix). Czech Geological Survey, Prague. ISSN 1214-1119. Manuscript received June 13, 2013; accepted in revised form October 29, 2013; published online December 12, 2013; issued January 21, 2014.

Linda Frey, Carole Naglik, Richard Hofmann \& Christian Klug, Palaeontological Institute and Museum, University of Zurich, Karl Schmid-Strasse 4, CH-8006 Zurich, Switzerland; linda.frey@uzh.ch; carole.naglik@pim.uzh.ch; richard.hofmann@pim.uzh.ch; chklug@pim.uzh.ch・Mena Schemm-Gregory, in memoriam・Jiř̌ Frýda, Faculty of Environmental Science, Czech University of Life Sciences, Kamýcká 129, 16521 Praha 6 - Suchdol, Czech Republic; bellerophon@seznam.cz • Björn Kröger, Freie Universität Berlin, Geologische Wissenschaften, Fachrichtung Paläontologie, Malteserstrasse 74-100,D-12249 Berlin, Germany; bjoekroe@gmx.de•Paul D. Taylor, Department of Earth Sciences, Natural History Museum, Cromwell Road, SW7 5BD London, United Kingdom; p.taylor@nhm.ac.uk• Mark A. Wilson, Department of Geology, College of Wooster, Wooster, OH 44691-2363; mwilson@wooster.edu

The eastern Anti-Atlas in Morocco is famous for its highly fossiliferous Palaeozoic rocks. Many palaeontological and stratigraphical studies on the Devonian of the Tafilalt and the Maïder have been carried out during the twentieth and twenty-first century (Clariond 1934a, b; Roch 1934; Termier \& Termier 1950; Massa et al. 1965; Hollard 1967, 1974, 1981; Alberti 1980, 1981; Becker \& House 1994, 2000; Bultynck \& Walliser 2000a, b; Klug 2001, 2002; Klug et al. 2008a, b; De Baets et al. 2010; Franchi et al. 2012). Well-exposed sedimentary successions of the Early
Devonian age crop out in the Tafilalt, e.g. between the Jebel Ouaoufilal and the mine of Filon 12 (Fig. 1). These more or less complete exposures, the local abundance of fossils and their sometimes excellent preservation yield the possibility to study Early Devonian faunal associations in their stratigraphic context in the Tafilalt.

In this study, we describe and figure well-preserved macrofossils of five Early Devonian faunules (earliest Lochkovian to early Emsian, according to Bultynck \& Walliser 2000b), which comprise a highly diverse Pragian 


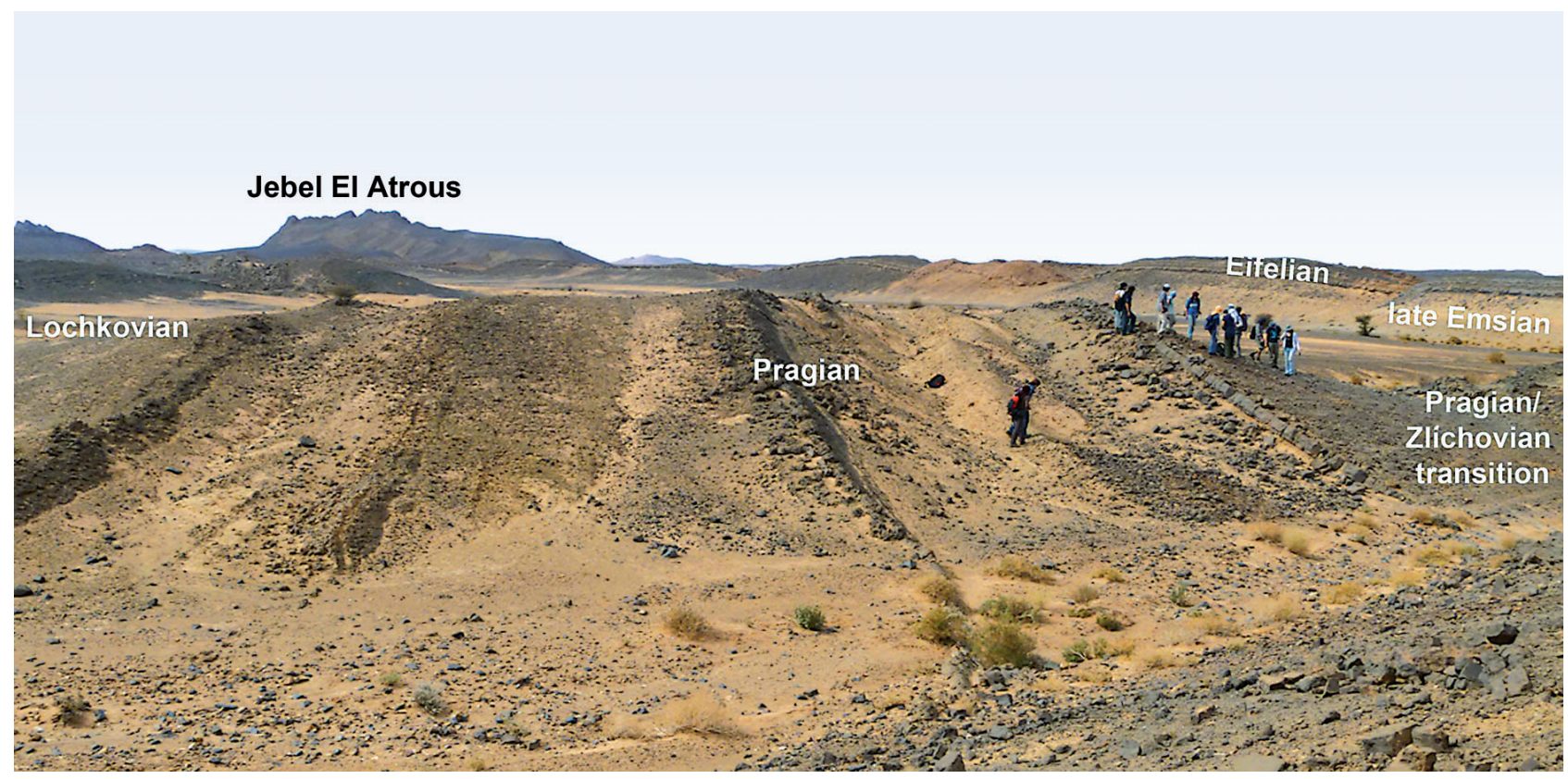

Figure 1. Field photograph of the outcrop near Jebel Ouaoufilal and Filon 12. Image courtesy of Richard Hofmann (Zurich).

fauna of the Jebel Ouaoufilal (Filon 12). We found species of cephalopods, gastropods, anthozoans, brachiopods, trilobites, bivalves, crinoids, hederelloids, rostroconchs, hyolithids and machaerids, the larger representatives of which are sometimes covered by epizoans. Our main focus is on these Early Devonian faunules, which we examined for alpha diversity and palaeoecology. Fluctuations in species richness and palaeoecology during the Early Devonian of Morocco have been noted before by several authors (e.g., Massa et al. 1965, Hollard 1974, Belka et al. 1999, Klug et al. 2008a, Kröger 2008). Belka et al. (1999) and Kröger (2008) recognized an increase in diversity, especially in benthic species, over time during the Early Devonian of the Tafilalt and correlated it to a change in oxygen content at the sea floor. This hypothesis was, however, not yet tested by collecting and analysing quantitative data. Kröger (2008) examined species richness and composition of the cephalopod associations at the Filon 12-section, but statistical analyses on the species diversity of all groups of macroscopic invertebrates over the whole Early Devonian interval have not been executed before. A palaeoecological study of the Tafilalt including two Emsian faunules was published by Klug et al. (2008a). They observed an ecological change in the early Emsian (Zlíchovian, sensu Bultynck \& Walliser 2000b) based on two species rich faunules that differ in species composition.

To investigate the changes in species richness and the local palaeoecology from the earliest Lochkovian to the early Emsian in the Tafilalt quantitatively, we analysed the faunules based on alpha diversity and ecospace use. The term alpha diversity was introduced by Whittaker
(1960, 1972), who described the species richness within a single habitat or community. The three-dimensional display of ecospace utilisation, developed by Bush et al. (2007), consists of multiple ecological parameters, to which each species can be assigned. These parameters are vertical tiering, motility level and feeding mechanism. We employed the same ecological parameters in our analysis. Additionally, the analysis of ecospace utilisation of the Moroccan Early Devonian faunules may reveal local macroecological changes, which were linked with the "Devonian nekton revolution" (Klug et al. 2010). The "Devonian nekton revolution" refers to a radiation of marine nektonic animals due to the rapid occupation of the water column in the Devonian and the synchronous decrease in planktonic and demersal taxa.

The aims of our study are (1) to describe and illustrate the well preserved macrofossil material of five successive Early Devonian faunules from the Tafilalt, (2) to describe new taxa of the highly diverse Pragian faunule, (3) to quantitatively analyse changes in alpha diversity and ecospace use through the Early Devonian of the southern Tafilalt, and (4) to discuss possible environmental and evolutionary factors, which might have initiated, controlled or influenced these changes in diversity and ecology.

\section{Material and methods}

All the fossil specimens listed, figured and described in this work come from the locality Jebel Ouaoufilal in the Tafilalt 
of Morocco (e.g. Klug et al. 2000, 2013). This locality is sometimes also called Filon 12 (e.g., Kröger 2008) after the local mine, which is world-renowned for its excellent vanadinite crystals and associated minerals.

The associations described here are earliest Lochkovian to early Emsian age ("Scyphocrinites"/Camarocrinus level to Erbenoceras/Anetoceras level; see Bultynck \& Walliser 2000b, Corriga et al. 2013). They were collected from the extensive outcrops of Devonian strata between the southwestern flank of Jebel Ouaoufilal, which is composed of Early Carboniferous siliciclastics, and the mentioned mine Filon 12. This area is located $7 \mathrm{~km} \mathrm{~W}$ of Taouz and $40 \mathrm{~km} \mathrm{~S}$ of the town of Rissani. The Early Devonian section can be found approximately at the coordinates $\mathrm{N}$ $30^{\circ} 56^{\prime} 57^{\prime \prime}, \mathrm{W} 04^{\circ} 02^{\prime} 39^{\prime \prime}$.

The samples of early to late Lochkovian age were taken bed by bed, whereas the samples of the lowermost Lochkovian, the Pragian and the early Emsian (early Zlíchovian) strata were collected from clayey to marly intervals. These intervals lie between limestone beds that form shallow ridges (as visible in Fig. 1) and so, the transport of material was limited to a few meters. Therefore, the according data do probably contain a slight bias from timeaveraging and the sampling method. Some of the fossils, such as the large loboliths of the crinoid Camarocrinus, were identified and counted in the field in order to keep the weight of samples reasonably low. The remaining, mostly small, specimens of the faunules were quantitatively sampled and studied in the lab for species identification and subsequent specimen counts (abundance). We defined whole fossils or fossil fragments as single individuals except fin spines of the acanthodian genus Machaeracanthus. Machaeracanthus possessed four fin spines (Südkamp \& Burrow 2007), and in order to account for the possibility that some of the fragments might have been parts of one spine or of several spines of one individual, we divided the total number of spines by two (although this number is admittedly arbitrary). Similarly, we did not include crinoid columnals in the study, because it was impossible to estimate the number of crinoid individuals since the crinoids were never entirely articulated. In the case of the genus Camarocrinus, we counted the loboliths, because only one of these buoyancy devices was present in each individual (Haude 1992).

The species counts were plotted as histograms per faunule and per ecological guild per faunule. Abundance and diversity data were rarefied for each faunule with the software package PAST (Hammer et al. 2001), in order to reduce the sampling bias and to compare more objectively the species richness of the faunules, which are of different sample sizes (Sanders 1968).

After these investigations, we grouped all taxa according to ecological categories compiled by Bush et al. (2007), who classified marine animals with respect to vertical tier- ing, motility level and feeding mechanism. Vertical tiering is defined by the vertical distribution of animals in or on the sediment as well as in the water column and includes the categories pelagic, erect, surficial, semi-infaunal, shallow infaunal und deep infaunal (Ausich \& Bottjer 1982, Bottjer \& Ausich 1986, Bush et al. 2007).

To the pelagic group, we assigned animals that lived in the water column. This includes the nekton such as fishes and certain cephalopods and the plankton such as the specialized genus Camarocrinus, which probably drifted at the water surface with its lobolith functioning as a buoy (Haude 1992). All other crinoid species were stalked and thus were interpreted as erect benthonic animals, which were attached to the seafloor or to objects on the seafloor with their body parts reaching more or less far into the water column. Less highly erected benthonic organisms such as brachiopods, bryozoans, corals, gastropods, hyoliths, hederelloids, phyllocarids, trilobites, and some bivalve species, we allocated to the category surficial. Rostroconchs, pyrgocystid edrioasteroids and some bivalves belonged to semi-infaunal animals (Kř́ž 2000, Klug et al. 2008a). Machaerids, the bivalve Panenka and palaeotaxodont bivalves are assigned to the shallow infaunal benthos, whereas only one deep infaunal bivalve species was found (Křǐž 2000, Klug et al. 2008a).

Motility level refers to the locomotory capabilities of organisms and is subdivided in six categories: freely, fast or slow motile animals, attached or unattached facultatively motile animals and attached or unattached non-motile animals (Bush et al. 2007). Freely, fast motile organisms are represented by fishes and some arthropods because of their active locomotion by fins or legs in the water column or on the sea floor. Cephalopods including Actinocerida, Pseudorthocerida, Oncocerida, and Orthocerida were either slow swimming or vertically migrating animals that lived in the water column; they were rather slow swimming compared to many modern decabrachian coleoid cephalopods (e.g., Westermann 1999, Westermann \& Tsujita 1999). Therefore, we assigned cephalopods together with gastropods and machaerids to the freely moving, slow motile category. According to Kř́iž (2000), most bivalves included in the study are considered as unattached, facultatively motile animals or, in the case of epibyssate bivalves, to attached, facultatively motile organisms. Corals, crinoids, bryozoans, hederelloids, edrioasteroids and brachiopods belonged to the non-motile/ attached animals (Racheboeuf 1990, Williams et al. 2000). The unattached non-motile category includes rostroconchs, hyoliths and a species of brachiopods (?Dagnachonetes sp.) (Williams et al. 2000).

"Feeding mechanism" categorises the behaviour of organisms to acquire food and is grouped in six subdivisions: suspension feeding, surface deposit feeding, mining, grazing, predatory and other (Bush et al. 2007). We consider 


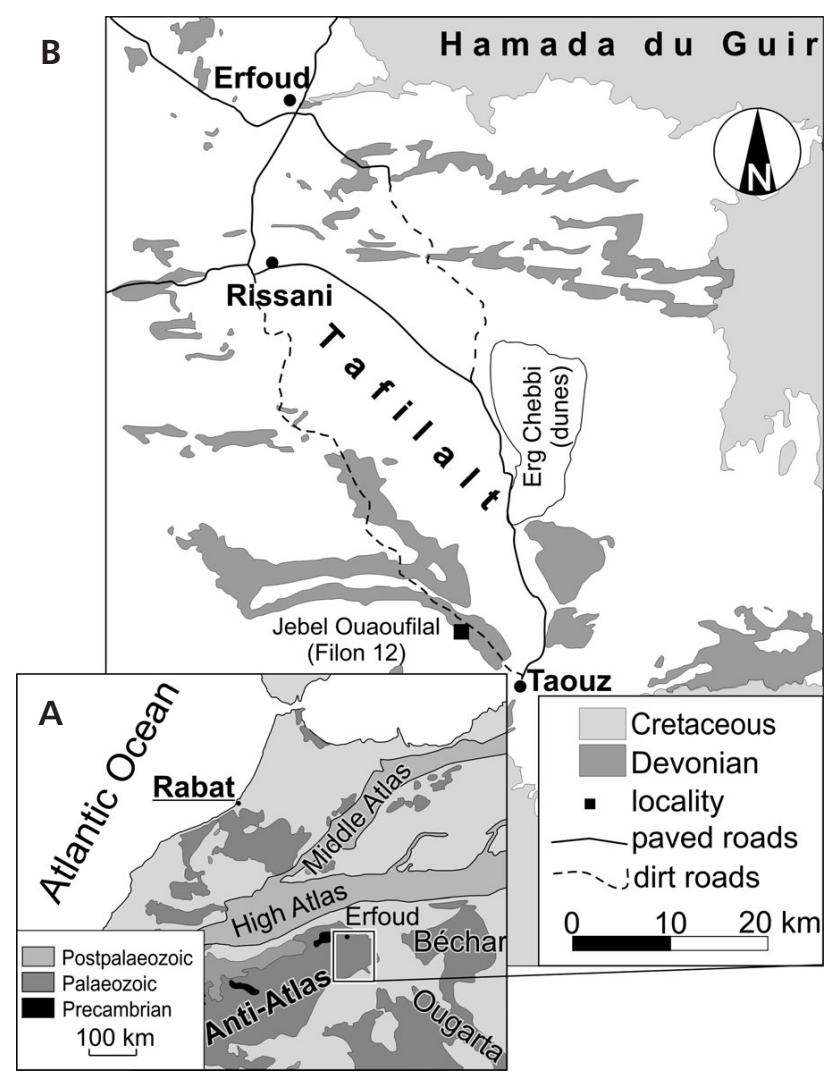

Figure 2. Geological map of Morocco. • A - distribution of Palaeozoic rocks in the Anti-Atlas. $\bullet$ B - map of Devonian outcrops in the Tafilalt.

tabulate corals, brachiopods, rostroconchs, bryozoans, hederelloids, crinoids, edrioasteroids, hyoliths, phyllocarids and epibyssate bivalves as suspension feeders that fed on small planktonic organisms from the water column. The majority of the bivalve species found in our Early Devonian faunules fed on buried nutrition and, therefore, mining was the common feeding mechanism. The predatory category includes fishes, rugose corals, nautiloids and trilobites that were able to catch prey capable of escaping and resisting. The trilobites of the faunules include members of the Orders Phacopida and Corynexochida that were supposedly microphagous predators because of the shape of their cephalon, the way of the attachment of hypostomes and the well-developed sensory fields (Eldredge 1971, Miller 1976, Whittington 1988, Fortey \& Owens 1999). We assigned the cephalopod species to microphagous predators as well based on the actualistic knowledge about the diet of modern Nautilus species. However, no undisputable cephalopod beaks older than Late Devonian are known. In the crop and stomach contents of recent Nautilida, fragments of small crustaceans and molts of larger crustaceans were found, which were detected by their chemosensory tentacles (Saunders \& Ward 1987). Bush et al. (2007) grouped all remaining feeding behaviours together as "others". We added the new category "coprophagy". Two coprophagous species in the study belong to a single gastropod Family, the Platyceratidae (Peel 1984; Gahn \& Baumiller 2003, 2006; Webster \& Donovan 2012; Donovan \& Webster 2013).

The classification of taxa according to vertical tiering, motility and feeding mechanism led to different combinations of ecological categories, which represent different modes of life (Bush et al. 2007). We evaluated how many species and individuals per mode of life were present in each faunule and how their relative abundances changed through time. Additionally, the trophic nucleus concept was used to reveal which species and modes of life dominate the faunules. The trophic nucleus is defined by those species that contribute to $80 \%$ of all individuals of a fauna (Neyman 1967).

The morphometric parameters for the description of cephalopod conchs were adopted from Teichert et al. (1964) and Kröger (2008). For the description of crinoids, we used terms and parameters adopted from Ubaghs (1978) and Jell \& Jell (1999). The descriptive terms and measurements for the description of gastropods were derived from Cox (1960). Morphometric parameters of hederelloids were adopted from Bassler (1953) and Taylor \& Wilson (2008).

All the material used for this study is housed in the Paläontologisches Institut und Museum der Universität Zürich (PIMUZ 30587-30662). A second sample of the newly introduced hederelloid genus Filihernodia was deposited in the Department of Earth Science of the National History Museum in London (NHMUK PI BZ 7494).

\section{Geological background}

The Moroccan Anti-Atlas is a broad NE-SW oriented Variscan anticlinorium, which makes up a part of the northern margin of the Sahara Craton (Piqué \& Michard 1989). Palaeozoic sedimentary rocks can be found along a NE-SW trending axis in the Anti-Atlas and include Devonian outcrops that cover an area of about $20.000 \mathrm{~km}^{2}$ (Kaufmann 1998; see Fig. 2A). Devonian rocks are exposed along E-W trending synclines in the Tafilalt but parts of these rocks are interrupted by reverse faults with strike-slip components (Toto et al. 2008). Especially, the Silurian and Early Devonian claystone successions were deformed and/ or cut by faults, which led to incomplete exposures of the Early Devonian rock succession in the Tafilalt, especially in parts of the southern flanks of the synclines. Some exceptions are probably the southeastern limb of the so-called Amessoui-syncline between the abandoned village El Atrous, the mine of Filon 12, Taouz, and the Jebel Ouaoufilal (Klug et al. 2013, see Fig. 2B).

In the Early Devonian, the Anti-Atlas was situated between $40^{\circ}$ to $60^{\circ}$ south (Scotese 1997 ). Moderately cool 


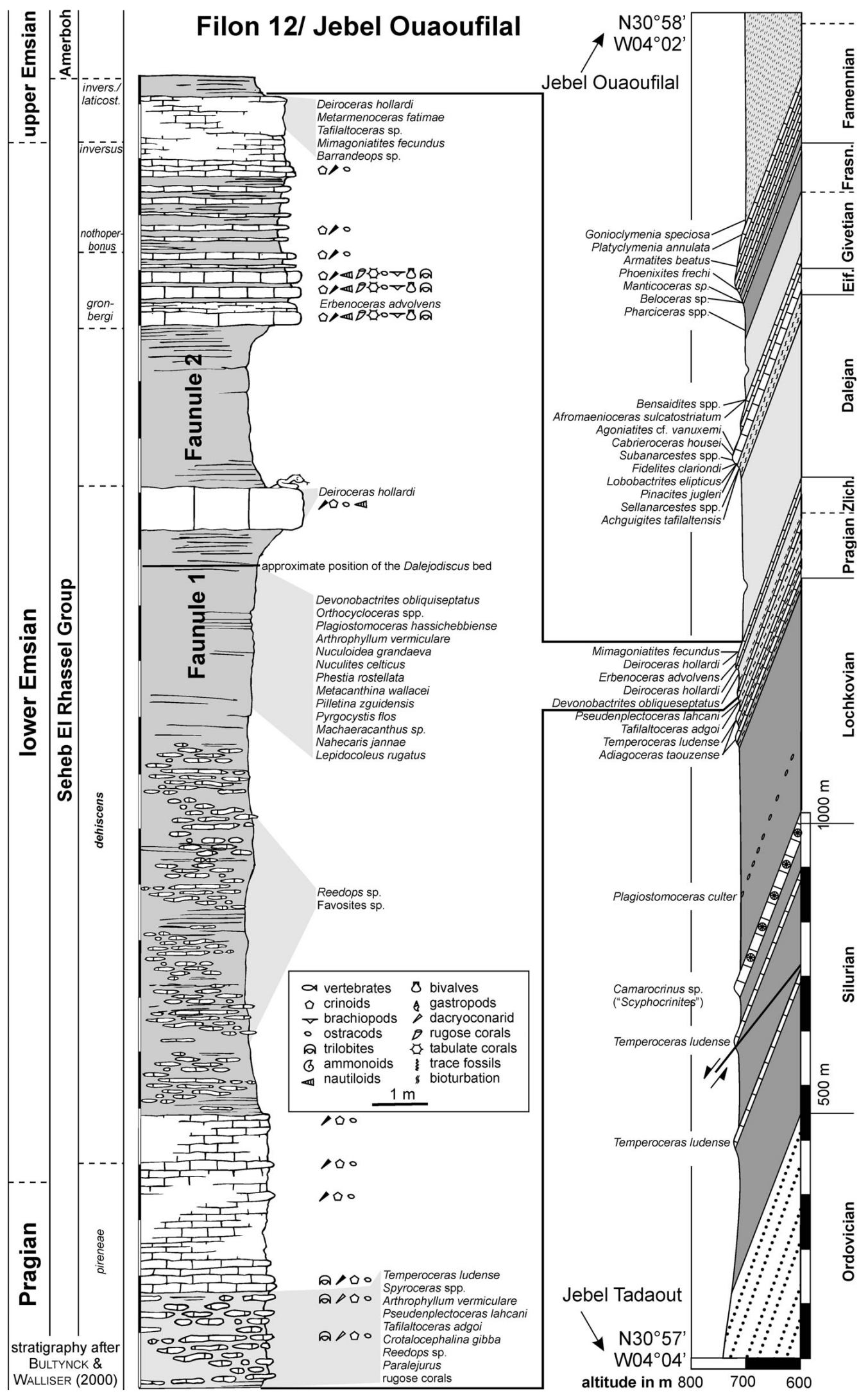

Figure 3. Devonian section at Jebel Ouaoufilal (Filon 12). Modified after Klug et al. (2013). The section on the right has the same scale in horizontal and vertical direction $(1: 10,000)$. 
water temperatures on the shelves of western and northern Gondwana have been confirmed by oxygen isotope analyses by van Geldern et al. (2006, see also Lubeseder et al. 2009). Early Devonian deposits display a rather uniform, mostly clayey to marly facies as well as moderate thickness changes in the eastern Anti-Atlas (Belka et al. 1997, Kaufmann 1998).

In the late Silurian and early Lochkovian (Early Devonian) successions, claystones are prevalent (Hollard 1981). These often dark coloured claystones (which are light greyish to pinkish when weathered) contain intercalated marlstone and limestone successions, which were formed by concentrated accumulations of planktonic crinoids (e.g. the scyphocrinoid limestone in which scyphocrinoid ossicles occur in rock-forming numbers), few orthoconic cephalopod shells (although some thin limestone interbeds are almost entirely composed of cephalopod shells) and occasionally bivalves as well as platyceratid gastropods (Haude 1992, Brachert et al. 1992, Kř́iž 2000, Lubeseder et al. 2009, Corriga et al. 2013). The limestones were deposited under low oxygen conditions below the storm wavebase and are characterized by massive beds with a maximum thickness of approximately $1 \mathrm{~m}$ near Filon 12 (Kř́ž 1998, Kröger 2008, see Fig. 3).

In the early Lochkovian, approx. $40 \mathrm{~m}$ above the Scyphocrinites Beds, marls with nodules dominated by the orthoconic cephalopod Plagiostomoceras culter are following near Filon 12 (Kröger 2008, Klug et al. 2013). In the late Lochkovian succession of dark claystones, some layers of dark grey to almost black more or less nodular limestones occur, which contain cephalopods, nowakiids, bivalves and a moderately low diversity in benthic species. Despite the presences of some benthic species, the facies of these limestones in combination with the predominance of freely motile cephalopods points at low oxygen conditions in and on the sediment (Klug et al. 2013).

In the Pragian and Emsian, the carbonate content of the sediments is clearly higher than in the Lochkovian deposits, which is reflected by the dominance of marls and nodular limestones (Hollard 1981, Lubeseder et al. 2009). These limestones are much lighter in colour suggesting a lower content in organic material which points at more oxygenated conditions at the sea floor (Klug et al. 2013). In the Filon 12 section, Pragian strata contain four limestone layers, which are alternating with nodular marly limestones with macrofossils (Kröger 2008). Especially in the claystone succession above the limestone "K3" of Kröger (2008), several nodular limestone layers occur, which are very rich in macrofossils such as trilobites, cephalopods, echinoderms, gastropods, tabulate and rugose corals (Klug et al. 2008a, Kröger 2008). The last limestone bed is overlain by light greyish marls, which are overlain by greenish claystones with limonitised faunas as well as limonite pseudomorphoses after pyrite. The localisation of the boundary between the Pragian and the Emsian is highly controversial and here, we were following the stratigraphy introduced by Bultynck \& Walliser $(2000 a$, b) for the Tafilalt. Accordingly, the Pragian-Emsian boundary is probably located near the base of the greenish claystones in the Tafilalt (Walliser 1984, 1985; Bultynck \& Walliser 2000b; Klug et al. 2008a; Klug et al. 2013; Kröger 2008).

In the greenish claystones, a highly fossiliferous fauna of the early Emsian, "faunule 1" sensu Klug et al. (2008a) and De Baets et al. (2010), occurs. These claystones are followed by the "Deiroceras limestone" with abundant large Deiroceras hollardi and are overlain by claystones of "faunule 2" described by Klug et al. (2008a) in the northern Tafilalt (see also Kröger 2008). The subsequent Erbenoceras Limestone consists of fossiliferous wackestones containing dacryoconarids in great abundance as well as subordinate crinoid ossicles, corals, trilobites, ostracods, bivalves, brachiopods, and the early ammonoids Erbenoceras advolvens as well as Anetoceras sp. (Klug 2001, De Baets et al. 2013).

The Erbenoceras limestones are overlain by an over $100 \mathrm{~m}$ thick claystone sequence. These claystones were deposited during and after the initial Daleje transgression (see, e.g., Kröger 2008, Lubeseder et al. 2009, Klug et al. 2013). During the late Emsian, the carbonate content increased more or less steadily and stayed high during much of the Middle and parts of the Late Devonian succession in the Amessoui Syncline (Döring 2002, Fröhlich 2004). In the late Middle Devonian, a platform and basin topography began to form, driven by early Variscan tectonic movements and differential subsidence (Wendt et al. 1984; Wendt 1985, 1988). Four depositional areas developed in the Anti-Atlas: the Maïder Platform, the Maïder Basin, the Tafilalt Platform and the Tafilalt Basin (Wendt 1988, Belka et al. 1997, Klug \& Korn 2002).

\section{Faunules of the earliest Lochkovian to early Emsian}

\section{Faunule 1 (Fig. 4A/ Table 1 in Appendix), earliest Lochkovian}

This faunule was found in the basalmost rocks of the section, representing the Silurian-Devonian boundary beds. This is corroborated by the presence of the plate-loboliths ("Platten-Lobolithen") and conodonts (Haude \& Walliser 1998, Corriga et al. 2013). We found four taxa including species of Camarocrinus, orthoconic cephalopods, bivalves and platyceratid gastropods. Ecospace consists of four modes of life (see Fig. 5). The trophic nucleus includes $\mathrm{Ca}$ marocrinus sp. and an orthocerid species, which belong to the unattached pelagic, non-motile suspension feeders and pelagic, slow motile predators. 

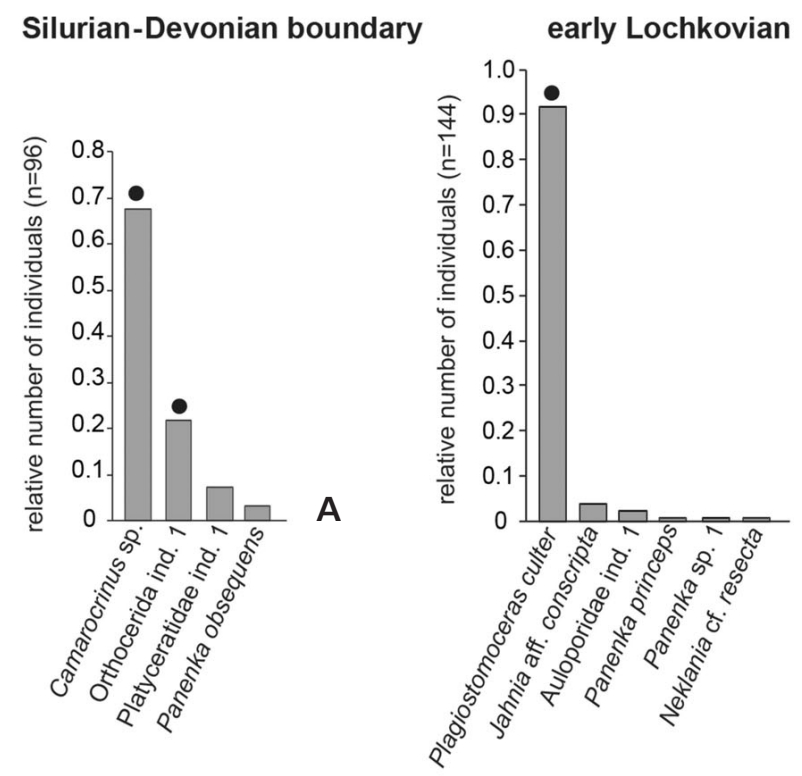

Pragian
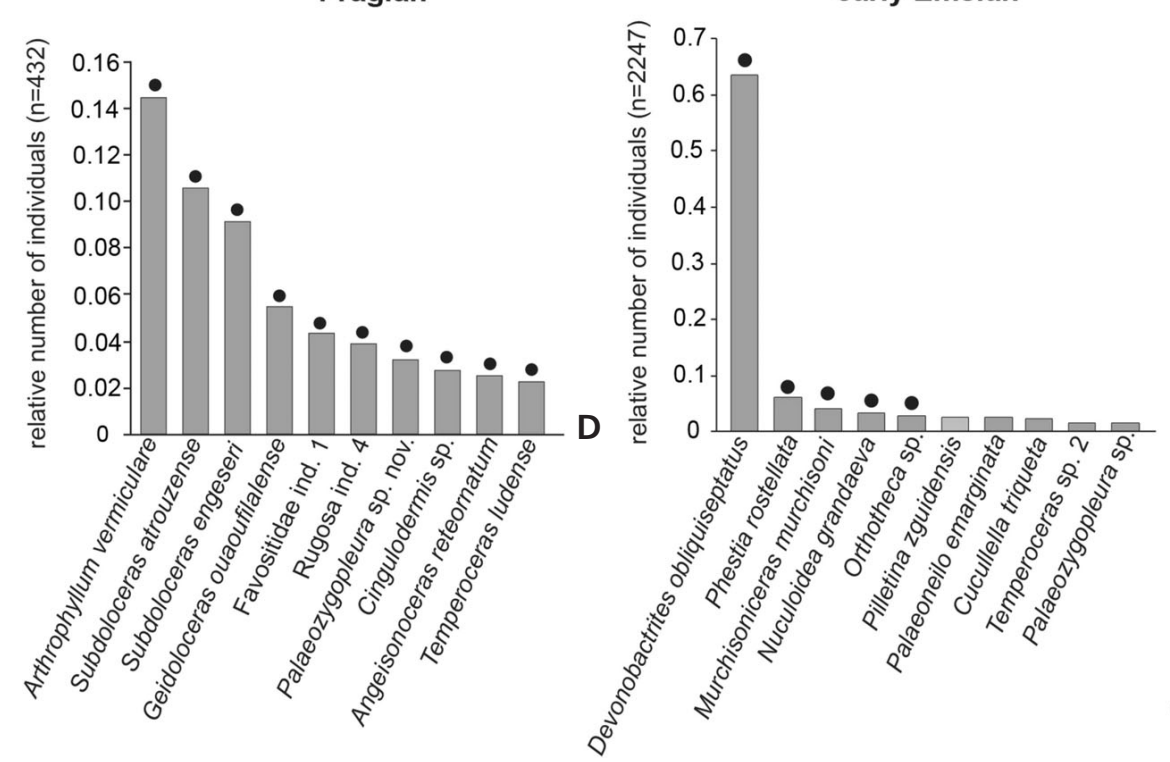

late Lochkovian
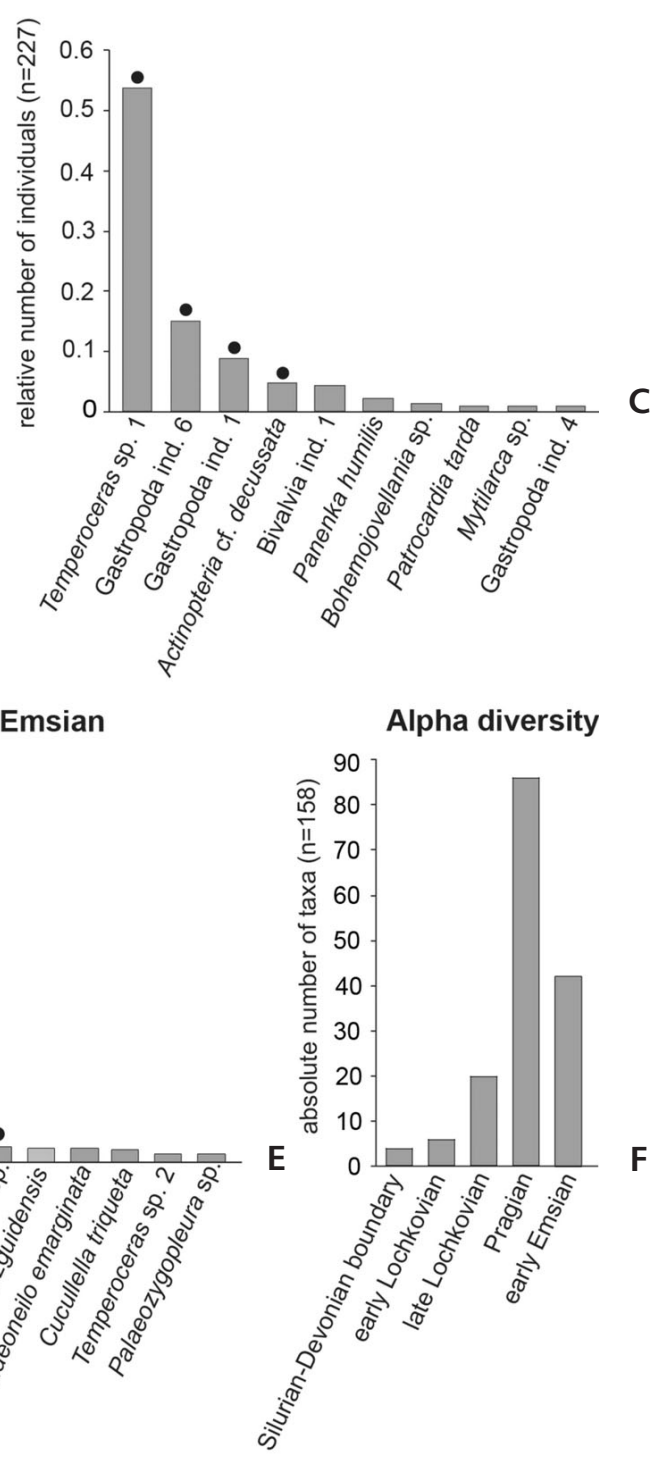

Figure 4. Alpha diversity of the species found in the earliest Lochkovian to early Emsian rocks at the Jebel Ouaoufilal (Filon 12) in the Tafilalt (Morocco); dots above the bars mark the dominant species of the faunules. • A - Silurian-Devonian boundary, all 4 sampled taxa depicted. $\bullet$ B - early Lochkovian, all 6 sampled taxa depicted. $\bullet$ C - late Lochkovian, only 10 taxa out of 20 sampled taxa illustrated. $\bullet$ D - Pragian, only 10 taxa out of 87 sampled taxa illustrated. $\bullet$ E - early Emsian, 10 taxa out of 42 sampled taxa illustrated. $\bullet \mathrm{F}$ - overview of the changes in alpha diversity during the Early Devonian of the Taouz area. Additional taxa are listed in the appendix (Table 1).

\section{Faunule 2 (Fig. 4B/ Table 1 in Appendix), early Lochkovian}

The second faunule of the section is of early Lochkovian age (Belka et al. 1999). Species richness is limited to six taxa that include infaunal bivalves, a species each of cephalopods and of tabulate corals. Ecospace utilization is limited to three modes of life (see Fig. 5). The trophic nucleus contains the orthocerid species Plagiostomoceras culter, which is a pelagic, slow motile predator.

\section{Faunule 3 (Fig. 4C/ Table 1 in Appendix), late Lochkovian}

This faunule of our Jebel Ouaoufilal section is of late Lochkovian age (Klug et al. 2013) and species richness is composed of 20 species, which comprises bivalves, gastropods, orthocerids, rare brachiopods and one bryozoan species. The ecospace utilization includes six modes of life (see Fig. 5). Four species contribute to the trophic nucleus: Temperoceras sp. 1, Gastropoda ind. 6, Gastropoda ind. 1 and 


\section{Ecospace use}

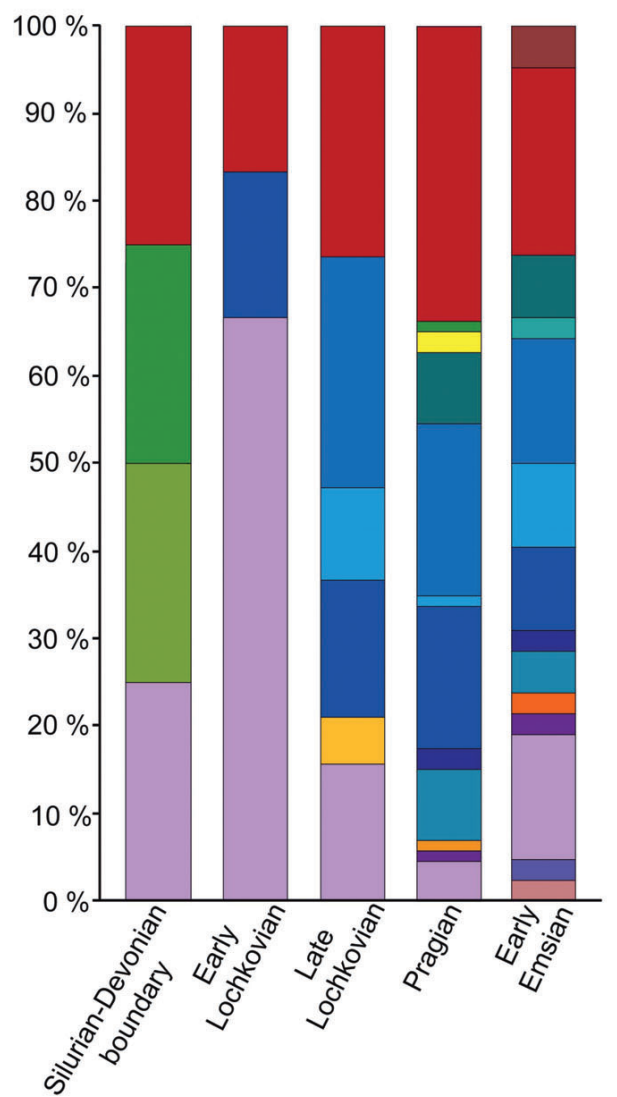

pelagic, fast motile predators

nelagic, slow motile predators

u unattached pelagic, facultatively motile, coprophagous

$\square$ unattached pelagic, non-motile suspension feeders

$\square$ attached erected, non-motile suspension feeders

- surficial, fast motile predators

$\square$ surficial, fast motile suspension feeders

a surficial, slow motile grazers

$\square$ attached surficial, facultatively motile suspension feeders

attached surficial, non-motile suspension feeders

- unattached surficial, non-motile suspension feeders

$\square$ attached surficial, non-motile predators

$\square$ attached semi-infaunal, facultatively motile suspension feeders

$\checkmark$ unattached semi-infaunal, non-motile suspension feeders

$\square$ attached semi-infaunal, non-motile suspension feeders

- shallow infaunal, slow motile miners

$\square$ unattached shallow infaunal, facultatively motile miners

- attached shallow infaunal, facultatively motile suspension feeders

$\square$ unattached deep infaunal, facultatively motile miners

Figure 5. Changes in ecospace use during the Early Devonian (Silurian-Devonian boundary to early Emsian) of the Taouz area.
Actinopteria cf. decussata, which had modes of life such as freely pelagic, slow motile predators, freely surficial, slow motile grazers and attached semi-infaunal, facultatively motile suspension feeders.

\section{Faunule 4 (Fig. 4D/ Table 1 in Appendix), Pragian}

The faunule was found in the Pragian rocks of the section at the Jebel Ouaufilal (Klug et al. 2013). The species richness consists of 86 species and contains many orthocerids, actinocerids, oncocerids, gastropods, brachiopods, bivalves, crinoids, tabulate and rugose corals, arthropods, rostroconchs, hyolithids, machaerids and a new hederelloid genus. 12 modes of life contribute to the ecospace of this faunule (see Fig. 5). The trophic nucleus comprises 27 species and includes nautiloids, tabulate and rugose corals, gastropods, brachiopods, bivalves and trilobites. These species had six different modes of life: freely pelagic, slow motile predators, attached surficial, non-motile suspension feeders, surficial, slow motile grazers, attached surficial, non-motile predators, surficial, fast motile predators, unattached shallow infaunal, facultatively motile miners.

\section{Faunule 5 (Fig. 4E/ Table 1 in Appendix), early Emsian}

The faunule belongs to the uppermost sediments of the section and is of early Emsian age ("faunule 1" of Klug et al. $2010,2013)$. The faunule is composed of 42 species of bivalves, bactritids, orthocerids, actinocerids, oncocerids, gastropods, arthropods, corals, machaerids, fishes, and edrioasteroids. The ecospace consists of 14 modes of life (see Fig. 5). The trophic nucleus contains five species: Devonobactrites obliquiseptatus, Phestia rostellata, Murchisoniceras murchisoni, Nuculoidea grandaeva, Orthotheca sp. These species belong to four modes of life such as freely pelagic, slow motile predators, unattached deep-infaunal, facultatively motile miners, unattached shallow-infaunal, facultatively motile miners and unattached surficial, nonmotile suspension feeders.

\section{Diversity fluctuations}

To investigate changes in alpha diversity and faunal composition during the Early Devonian of the Taouz area, we identified as many of the fossils as possible and counted all taxa of every faunule and compared their abundances. At 
Silurian-Devonian boundary

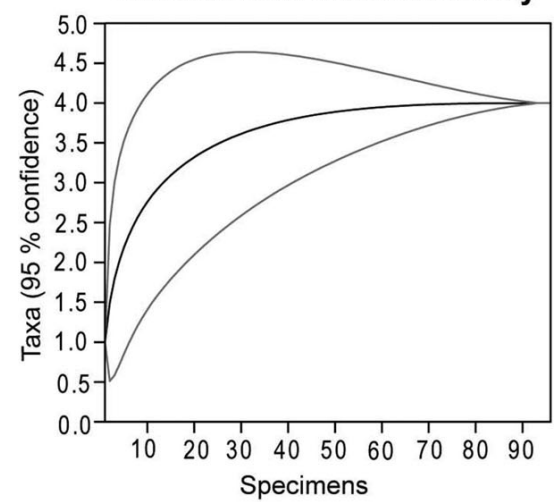

early Lochkovian

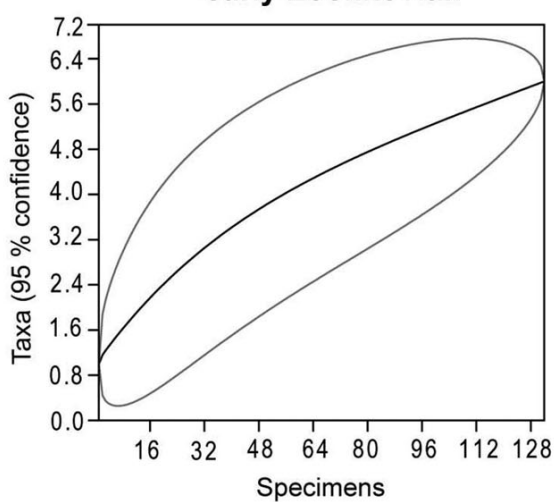

late Lochkovian

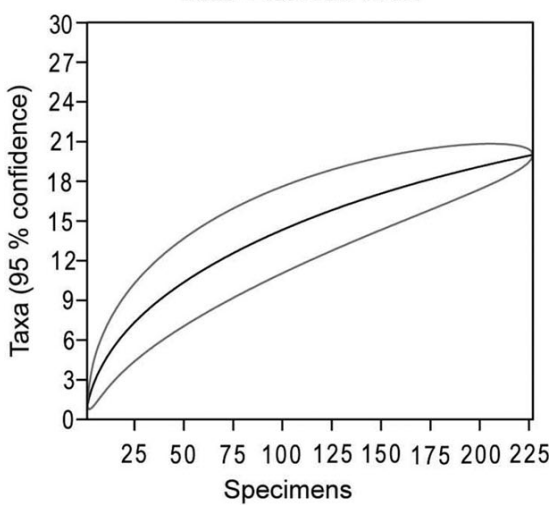

Pragian

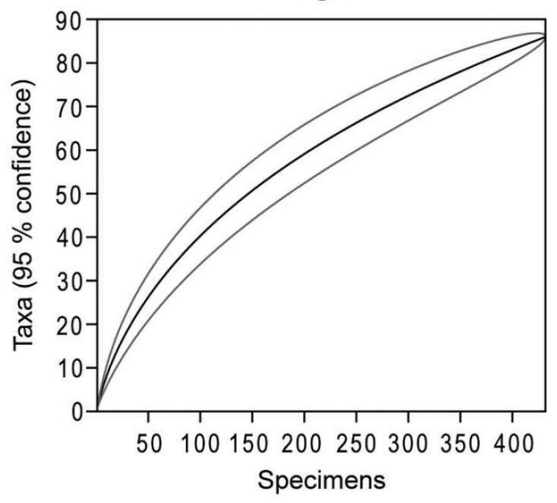

early Emsian

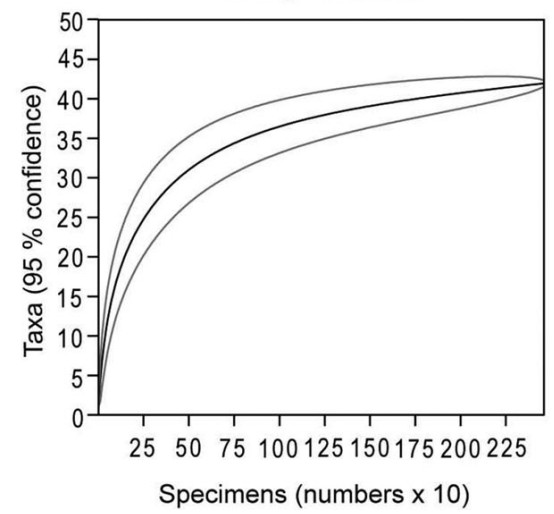

Figure 6. Rarefaction analyses of all Early Devonian faunules (earliest Lochkovian to early Emsian) collected from the Jebel Ouaoufilal (Filon 12).

the Silurian-Devonian boundary, the species richness was low. We found fossils of four species although we have missed some species of orthocerids, which according to Kröger (2008) occur therein. This is due to the fact that some layers are composed of almost only cephalopod shells while others are strongly dominated by Camarocrinus remains, i.e., when sampling for cephalopods, the focus is on the cephalopod strata but we focused on the youngest crinoid-layer. Nevertheless, we assume that the diversity would be similarly low in the cephalopod layers and benthos is certainly also rare therein.

The diversity in groups and species increased slowly from the early Lochkovian (6 species) to the late Lochkovian (20 species). During the Pragian, the species diversity reached its Early Devonian maximum (86 species). The early Emsian faunule (42 species) had a lower species diversity than the Pragian faunule.

These findings show that alpha diversity increased significantly from the Silurian-Devonian boundary to the Pragian and decreased somewhat in the early Emsian (Fig. 4F). Rarefaction analyses indicated that in all faunules except in the oldest (earliest Lochkovian) and the youngest faunules (early Emsian) studied here further collecting would increase the number of species in the faunal lists. The Pragian faunule still remains the most diverse among the examined faunules and we probably sampled only a fraction of the actual diversity (Fig. 6). In addition to the species diversity, the taxonomic composition of the examined faunules changed between the faunules and most of the species found in one faunule were not discovered in faunules of a different age. Furthermore, the number of invertebrate taxa of a higher systematic rank increased through time and vertebrate remains appeared in the two youngest faunules.

\section{Ecospace utilisation}

Grouping of species according to the categories of tiering, motility and feeding mechanism resulted in different combinations of categories reflecting different modes of life (Bush et al. 2007). These categories helped us investigating changes in ecospace occupation during the Early Devonian at our section of the Jebel Ouaoufilal (see Fig. 5).

The ecospace use at the Silurian-Devonian boundary is poor in modes of life. Especially unattached pelagic animals are common which are slow, facultative or nonmotile and which fed on feces, small food particles in the 
water column or small prey. Another mode of life is represented by unattached shallow infaunal, facultatively motile, mining bivalves. This result is, however, not entirely representative because of the relatively poor sampling. Most likely, we missed some species of orthocones and possibly also bivalves.

In the early Lochkovian faunule, three modes of life were present of which only one (unattached shallow infaunal, facultatively motile miners) dominated, reaching $67 \%$ relative abundance. This mode of life is represented by bivalves, which show a slight increase in diversity compared to the Silurian-Devonian boundary. Species of freely pelagic, slow motile predators that are represented by orthocones still exist but have a lower relative abundance (17\%) than in the faunule of the earliest Lochkovian (25\%). With the appearance of tabulate corals, a new mode of life (attached surficial, non-motile suspension feeders) occurred in the sedimentary sequence at Filon 12, while two modes of life from the Silurian-Devonian boundary (unattached pelagic, facultatively motile, coprophagous organisms or nonmotile suspension feeders) apparently vanished with the disappearance of the early Lochkovian faunule.

In the late Lochkovian faunule, three additional modes of life appeared: freely surficial, slow motile grazers, attached surficial, facultatively motile suspension feeders and attached semi-infaunal, facultatively motile suspension feeders. These modes were represented by gastropods, brachiopods, epibyssate and semi-infaunal bivalves. A total of six modes of life existed then but none of them is clearly dominant. The highest relative abundances of the Lochkovian faunule are represented by freely pelagic, slow motile predators and freely surficial, slow motile grazers (26\% for each).

In the Pragian faunule, six new modes of life appeared and so the number of modes of life had more than doubled. Especially surficial modes of life became more abundant and unattached semi-infaunal, non-motile and attached erect, non-motile suspension feeders were found for the first time. But of these 12 modes of life, the freely pelagic, slow motile predators have the highest relative abundance of almost $34 \%$. A further increase can be documented in "faunule 1" (Klug et al. 2008a, De Baets et al. 2010) of the early Emsian (14 modes of life). No mode of life is significantly dominant but freely pelagic, slow motile predators have the highest relative abundance $(21 \%)$. While five new modes of life were present, we did not rediscover two that existed in the Pragian (attached erect and unattached semi-infaunal, non-motile suspension feeders). We found fossils of freely pelagic, fast motile predators that were represented by two fish species and a small increase in semiinfaunal and infaunal modes of life (attached semi-infaunal, non-motile and attached shallow infaunal, facultatively motile suspension feeders, and unattached deep infaunal, facultatively motile miners).
We found evidence that the number of modes of life increased, and thus the ecospace use expanded from the Silurian-Devonian boundary towards the early Emsian. In the Early Devonian of the Taouz area, we found only 19 of the 216 theoretically possible modes of life. The number of modes of life recorded here corresponds well with the results of Bush et al. (2007), who found 21 modes of life for the mid Palaeozoic (Late Ordovician to Devonian) and 23 to 25 for the late Cenozoic (Miocene to Pleistocene) of North America and Europe. The specific types of modes of life found in the Early Devonian of the Taouz area mostly correspond to those found in the mid Palaeozoic by Bush et al. (2007). Differences between the two studies (the types of modes of life and their number) are influenced by the size of samples and study area, the time span, preservational biases and different palaeoenvironments. For example, Bush et al. (2007) described a tropical environment in the Palaeozoic of North-America while North Africa was situated in a more temperate climate (Kaufmann 1998, Scotese \& McKerrow 1990).

As we examined all categories of ecospace occupation of Bush et al. (2007) separately, we found an increase of ecological categories that were occupied by species over time in the section at the Jebel Ouaoufilal. The greatest change occurred in the Pragian faunule. At this time, the number of surficial species, freely walking or slowly swimming species and predator species had the highest absolute abundances within the classes of tiering, motility and feeding mechanism (see Fig. 7).

\section{Dominance changes in taxic composition and modes of life}

We examined changes in dominance based on analyses of the trophic nucleus. The trophic nucleus includes species, whose abundances contribute to $80 \%$ of the total number of specimens per fauna (Neyman 1967). Moreover, we analyzed to what modes of life (combination of tiering, motility and feeding mechanism according to Bush et al. 2007) the dominant species belonged (see Table 1 in appendix).

At the Silurian-Devonian boundary, the trophic nucleus contained two species and two different modes of life while only one species and a single mode of life were predominant in the early Lochkovian faunule. Compared to this, the late Lochkovian faunule contained more dominant species and modes of life ( 4 species, 3 modes of life). The distribution of dominance changed profoundly from the Lochkovian to the Pragian. 27 species and six modes of life were contributing to the trophic nucleus of the Pragian faunule. A strong decrease in the number of predominant species occurred in the early Emsian (5 species), whereas the number of modes of life only decreased to four modes of life (see Fig. 4A-E). 
Tiering

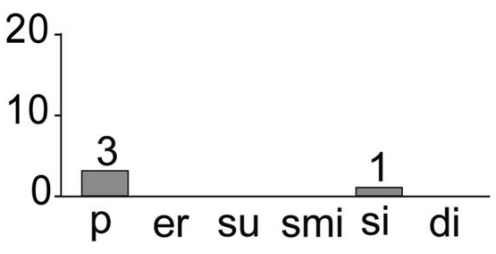

Motility

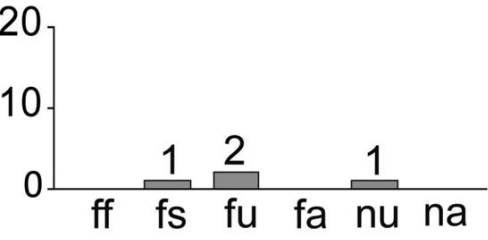

Feeding type

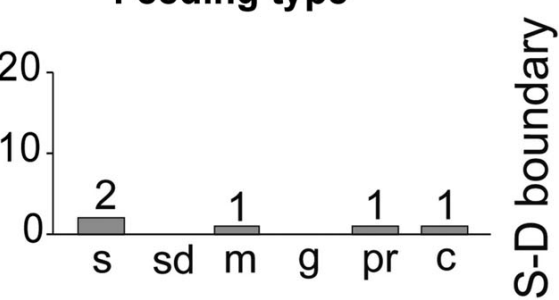

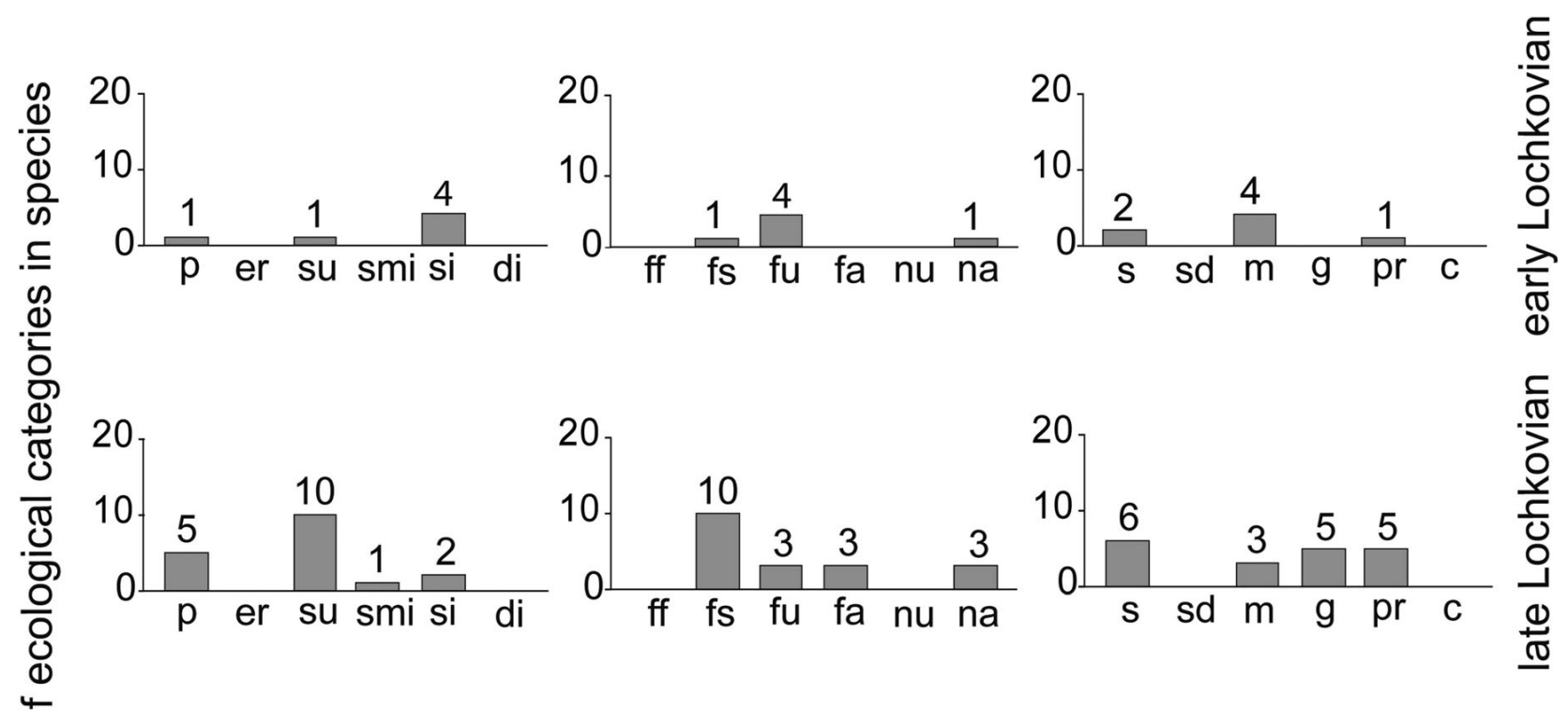
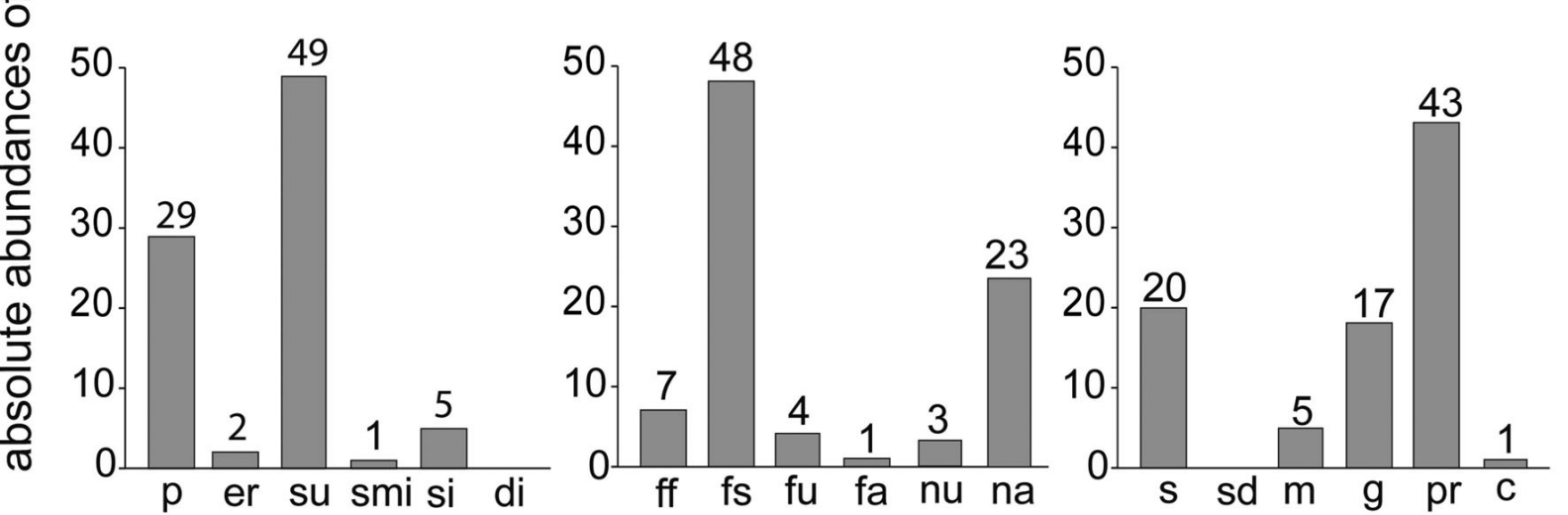

$\frac{\frac{\sigma}{0}}{\frac{\pi}{0}}$
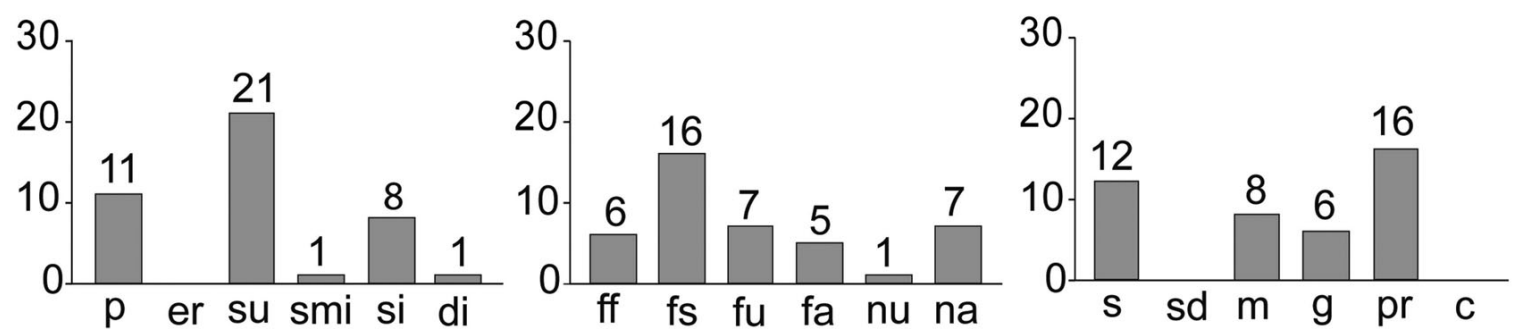



Figure 7. Changes in tiering, motility and feeding behaviour in the Early Devonian of the Taouz area. Ecological categories: Tiering - p: pelagic, er: erect, su: surficial, smi: semi-infaunal, si: shallow infaunal, di: deep infaunal; Motility - ff: freely fast, fs: freely slow, fu: facultatively unattached, fa: facultatively attached, nu: non-motile and unattached, na: non-motile and attached; Feeding type - s: suspension feeder, m: miner, g: grazer, pr: predators, c: coprophagous (Bush et al. 2007). 
The number of dominant species increased through time and the Pragian faunule with the highest species richness also had the highest number of dominant species. The trophic nucleus includes species with pelagic modes of life in the earliest Lochkovian and contains a lot of species of different groups and especially pelagic and surficial modes of life in the Pragian. In the early Emsian, the number of dominant species strongly decreased, and pelagic, infaunal and surficial modes of life are dominating.

\section{Discussion}

The alpha diversity increased from the Silurian-Devonian boundary to the Pragian and slightly decreased in the early Emsian of the Tafilalt. We found an expansion of the ecospace use and major changes in dominant species and modes of life in the trophic nuclei of the Early Devonian. Such changes in diversity and ecospace use can be caused by sea level changes, changes in oxygenation of the sediment and water on the sea floor, differences in salinity, or sediment input. A sampling bias might alter the primary data in such way, that a trend can be seen, which does not correspond to the actual original change in ecology. Sampling is affected by, e.g., different sample sizes, poor sampling and timeaveraging. The sampling bias due to sample size was reduced by rarefying the abundance data of the faunules by the software package PAST (Hammer et al. 2001). In how far the dimensions of the sampled intervals produced a bias is difficult to estimate. In our opinion, however, this change in diversity and ecology is real, because even in single beds, many more species and fossil groups can be seen in cross sections and furthermore, the Pragian diversity has been corroborated by others, who examined, e.g., Pragian trilobites (e.g. Alberti 1969). Time-averaging refers to the accumulation of a local community over time, which does not represent the local community structure at a single moment, because due to their short life spans, communities accumulate faster than sediments (Walker \& Bambach
1971). Therefore, short-term events are usually not visible in fossil assemblages. Indeed, the long-term trends as seen in the section at the Jebel Ouaoufilal reflect extreme changes in species richness and composition and the faunules were obviously affected by various environmental factors. Fluctuations in sea level or bottom oxygenation are possibly the reasons for changes in diversity and ecospace utilization. Littoral parts of the sea are mostly low in diversity because of high water currents and perturbations while the environment of the shelves is more stable and therefore has higher species richness (Ziegler 1972). The realms of the deep sea are poor in species because the supply of organic food usually decreases with water depth.

Many facts support the hypothesis that a sea level fall and additional oxygenation of the sea floor occurred during the Early Devonian in the Tafilalt. The faunule of the Silurian-Devonian boundary was poor in species and modes of life. Especially modes of life including pelagic species, such as orthocones, Camarocrinus and gastropods attached to Camarocrinus were abundant. The faunule was dominated by two species (Orthocerida ind. 1, Camarocrinus sp.) with following modes of life: freely pelagic, unattached non-motile suspension feeders and freely pelagic, slow motile predators. The missing benthos (except the infaunal bivalve Panenka obsequens) and the dominating pelagic species indicate low oxygen conditions on the sea floor and in the sediment during the earliest Lochkovian. Haude (1992) and Haude \& Walliser (1998) reported that the planktonic scyphocrinoids existed from the Late Silurian to the early Lochkovian when the deposition of organic material and therefore of black shales prevailed. This fact in combination with the dominance of other pelagic organisms (nautiloids and graptolites) and the commonly dark sediments rich in pyrite and organic matter, reflect hypoxic to anoxic conditions and thus poor living conditions at the bottom (Haude 1992). Křiž (2000) described a community of large infaunal bivalves ("Panenka Community"), which co-occurred with Scyphocrinites and cephalopods in the earliest Lochkovian of the Tafilalt. Based on the large size,

Figure 8. Lochkovian bivalves, Pragian trilobites and brachiopods from the Jebel Ouaoufilal in the Tafilalt. • A - Odontochile cf. hausmanni (Brongniart, 1822); fragment of the pygidium, $\times 1$; PIMUZ 30645. • B-D - Reedops cf. cephalotes hamalagdianus Alberti, 1983; dorsal view of the cephalon, lateral view of the whole specimen, dorsal view of the thorax, $\times 1$; PIMUZ 30646 . $\bullet \mathrm{E}-\mathrm{G}-$ Reedops bronni (Barrande, 1846); lateral view of the whole specimen, dorsal view of thorax and pygidium, $\times 1$; PIMUZ 30647. $\bullet \mathrm{H}, \mathrm{I}-$ Cheirurus (Crotalocephalus) sp.; dorsal and lateral view of the cephalon, $\times 2$; PIMUZ 30648. - J-N - Desquamatia sp.; lateral, dorsal, posterior, ventral and anterior view of the valves, $\times 1$; PIMUZ 30649 . - O-S - ?Aulacella eifeliensis (Verneuil, 1850); lateral, dorsal, posterior, ventral and anterior view of the valves, $\times 2$; PIMUZ 30650. $\bullet$ T-X - Brachipoda gen. et. sp. indet.; lateral, dorsal, posterior, ventral and anterior view of the valves, $\times 2$; PIMUZ 30651. $\bullet$ Y-AC - ?Protathyris sp.; lateral, dorsal, posterior, ventral and anterior view of the valves, $\times 2$; PIMUZ 30652. $\bullet$ AD-AO - Cingulodermis sp.; AD-AH - lateral, dorsal, posterior, ventral and anterior view of the valves, $\times 2$; PIMUZ 30653; AI-AO - lateral, dorsal, posterior, ventral and anterior view of the valves, $\times 2$; PIMUZ 30654 . $\bullet$ AP - aff. Eoglossinotoechia sp.; ventral view, $\times 2$; PIMUZ 30655. • AQ, AR - Panenka princeps Barrande, 1881; dorsal and lateral views, $\times 1$; PIMUZ 30656. - AS - Panenka humilis Barrande, 1881; lateral view, $\times 1$; PIMUZ 30657. • AT - Neklania cf. resecta Barrande, 1881; insight view of the left valve, $\times 1$; PIMUZ 30658. • AU - Jahnia aff. conscripta (Barrande, 1881); lateral view, × 3; PIUMZ 30659. • AV, AW - Actinopteria cf. decussata Hall, 1884; AV - lateral view, × 2; PIMUZ 30660; AW - lateral view of two specimens, $\times 2$; PIMUZ 30660. • AX - Mytilarca sp.; lateral view, $\times 1$; PIMUZ 30661. - AY - Patrocardia tarda (Barrande, 1881); lateral view, $\times 1$; PIMUZ 30662. 
Linda Frey et al. • Diversity and palaeoecology of Early Devonian invertebrate associations in the Tafilalt

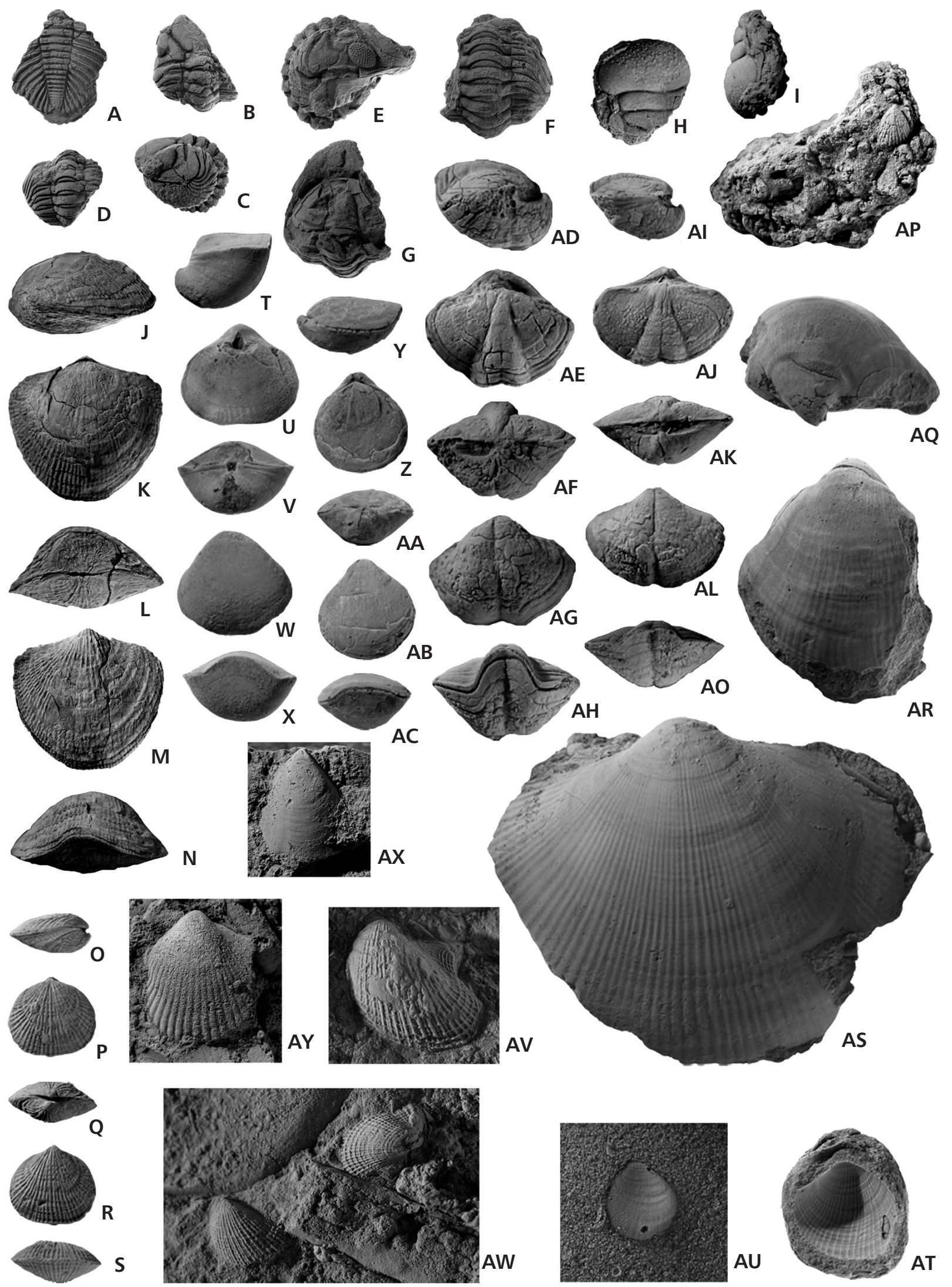


the low species diversity (Panenka obsequens, Panenka aff. bellula and Dualina sp.) and the preservation of the bivalves, he assumed a soft bottom environment with low oxygen conditions and low water movement at the sea floor. Unfortunately, we found only three individuals of Panenka obsequens and we did not find the other two species of the "Panenka Community" in our section at the Jebel Ouaoufilal (Filon 12). But the low diversity, the rather large size of the bivalves and the accompanying pelagic fauna indicates similar living conditions at the sea floor as reported by Kříž (2000).

In the early Lochkovian, the species diversity was higher because of the increased diversity in infaunal bivalves (Genera: Panenka, Neklania, Jahnia) and the appearance of a tabulate coral species. The ecospace use expanded slightly but the faunule still has a low diversity of modes of life, which include only pelagic and infaunal categories. A cephalopod species, which belonged to freely pelagic, slow motile predators (Plagiostomoceras culter), strongly dominated the faunule. These facts all together testify that the bottom water was still similarly low in oxygen as during the Late Silurian and earliest Lochkovian.

In the late Lochkovian, the increase in alpha diversity and the gentle increase in modes of life with the first appearance of surficial gastropods and brachiopods in the section indicated slightly improved living conditions at the sea floor. We noted that the faunule was no longer dominated by pelagic species but also comprised surficial, freely slow moving grazers (two gastropod species) and attached, semi-infaunal, facultatively motile suspension feeders (Actinopteria cf. decussata), which also reflected changes in the environment. The species composition of the bivalves was similar to the "Panenka-Jahnia-Neklania Community" described by Kř́ž (2000). This community contained a high diversity of infaunal bivalves and also epibyssate bivalves that indicate improved living conditions at the bottom due to higher oxygen content. In our sample, we found infaunal bivalves such as Panenka humilis, Neklania cf. obtusa and Jahnia sp., epibyssate bivalves such as Mytilarca sp. and Patrocardia tarda and the semi-infaunal bivalve Actinopteria cf. decussata (see Fig. 8). Unfortunately, a lot of taxa of the "Panenka-Jahnia-Neklania" community were missing. But higher diversity in infaunal species and appearance of semi-infaunal and epibyssate bivalves reflect a better ventilated sea floor and therefore better living conditions for benthic species in the late Lochkovian.

Subsequently, the extreme increase in alpha diversity from 20 species in the late Lochkovian to 86 in the Pragian, the increase in modes of life including surficial, erect, semi-infaunal and infaunal organisms and a highly diverse trophic nucleus (27 species, especially including pelagic and surficial modes of life) reflect good living conditions for benthonic as well as demersal life. In particular, the drastic increase in benthic species and the colour change of the sediment towards light grey permits the supposition that a steady rise of oxygen content near the seafloor occurred in combination with a sea-level fall. This is in accordance with the Devonian sea level curve of Morocco presented by Kaufmann (1998) and is linked to a conspicuous sediment colour change, which occurs in the entire Tafilalt (Alberti 1981, Belka et al. 1999, Bultynck \& Walliser 2000b, Kröger 2008). Kröger (2008) correlated the increase in benthic taxa and cephalopods species at the Filon 12 with the "pesavis Bioevent" or "Lochkovian-Pragian Boundary Event” (Chlupáč \& Kukal 1988, 1996; Schönlaub 1996), which coincides with global changes in sediment colours, benthic diversity and/ or taxonomic composition at the Lochkovian-Pragian boundary (Alberti 1969, Schönlaub 1996, Talent \& Yolkin 1987, Talent et al. 1993, Kř́̌ž 1998, Ferreti et al. 1999, Chlupáč et al. 2000, García-Alcalde et al. 2000). These facts in combination with the Devonian eustatic sea level curves (Johnson et al. $1985,1996)$ revealed a change of oxygen content of the sea floor caused by a potential global sea level fall.

The early Emsian fauna ("faunule 1" of Klug et al. 2008a) is also quite diverse although it contains less taxa (42 species), whereas the number of modes of life increased (from 12 modes of life in the Pragian to 14 in the early Emsian). The high abundance of surficial species led to the assumption that oxygen conditions in and on the sediment were similarly high as during the Pragian. Based on the faunal composition and the facies, Klug et al. (2008a) concluded that the environmental conditions of the early Emsian can be considered as favorable and reasonably well oxygenated; however, the commonly limonitic and formerly pyritic preservation of this fauna shows that only the top part of the sediment was oxygenated while deeper layers were probably anoxic. Analysis on the trophic nucleus of the early Emsian faunule shows an elementary change in the number of dominant species. There was an extreme decrease in dominant species (from 27 species in the Pragian to 5 in the early Emsian) and a slight decrease in modes of life (from 5 modes of life in the Pragian to 4 in the early Emsian) contributing to the trophic nucleus. Modes of life including pelagic and infaunal species were dominant in the early Emsian faunule, whereas only one surficial species was prevalent. This fact, in combination with the limonitised macrofossils and the occurrence of greenish claystones reflect a less well-oxygenated bottom than in the Pragian. Additionally, we found a high number of infaunal bivalve taxa belonging to the Palaeotaxodonta in the early Emsian faunule. Recent representatives of this group are known to tolerate moderately low oxygen conditions in the sediment. The decrease in bottom oxygenation could be explained by a transgression during the early Zlíchovian (Kröger 2008, Lubeseder et al. 2009). This early Emsian change in sea level possibly correlates to the transgressive cycle Ib sensu Johnson et al. (1996). 
In the present work, the discussed sea level changes mainly represent long-term trends in the Early Devonian of the Taouz area but naturally, many short-term fluctuations in sea level occurred in this time span as well. Alternations of limestones and claystones in our section at the Jebel Ouaufilal and in other sections in the eastern (Belka et al. 1999, Kröger 2008) and southwestern Anti-Atlas (Lubeseder et al. 2009) indicate numerous regional sea level fluctuations. Comparisons between our results and the sections of previous authors show similar changes in species richness and ecospace use during the Early Devonian in the Tafilalt, but lateral facies changes and diachronicity of boundaries are possible and should be examined in greater detail in the future.

In Early Devonian faunules of the Tafilalt, the ecological turnover of the "Devonian nekton revolution" (Klug et al. 2010) is predominantly reflected in the faunal changes at the transition from "faunule 1" to "faunule 2" (Zlíchovian, early Emsian) of Klug et al. 2008a, where parts of the abundance of non-ammonoid cephalopods were replaced by rather diverse early ammonoids (Klug et al. 2008a). Pelagic predators were already abundant in the Silurian and stayed common until the early Emsian but they mainly consist of slow motile microphagous orthocerids, actinocerids, oncocerids and bactritids. Nektonic predators such as the acanthodian Machaeracanthus were found in small numbers in the early Emsian faunule of our section. Demersal and planktonic species stayed dominant in the Pragian and early Emsian faunules in the Taouz area.

\section{Conclusions}

We examined five Early Devonian faunules near the Jebel Ouaoufilal in the southern Tafilalt for alpha diversity and ecospace utilization. All 3376 specimens were identified as far as possible and assigned to different modes of life including the ecological groups tiering, motility and feeding mechanism according to the method introduced by Bush et al. (2007). These analyses revealed a strong increase in species richness and an extension in ecospace utilisation during the Early Devonian (earliest Lochkovian to early Emsian sensu Bultynck \& Walliser 2000b) of the Taouz area. The highest number of species has been found in the Pragian and the expansion of ecospace utilization reached its maximum in the early Emsian. Especially taxa with surficial, slow motile or predatory modes of life became most diverse in the Pragian and decreased somewhat in the early Emsian. The number of dominant species contributing to the trophic nucleus increased from the Silurian-Devonian boundary to the Pragian and extremely decreased in the early Emsian. All these changes reflect favorable conditions for life on the sea floor during the Pragian of the Tafilalt. Increasing benthic and demersal diversity in the Prag- ian coincides with colour changes in sediments and faunal changes in the whole Tafilalt and other parts of the world at the Lochkovian-Pragian boundary (Alberti 1969, 1981; Talent \& Yolkin 1987; Talent et al. 1993; Kř́̌ž 1998; Schönlaub 1996; Ferreti et al. 1999; Belka et al. 1999; Bultynck \& Walliser 2000b; García-Alcalde et al. 2000; Chlupáč et al. 2000; Kröger 2008). The ecological change correlates with a steady rise of oxygen content near the bottom in combination with a regional if not global regression. This is in accordance with existing Devonian sea level curves of Morocco (Kaufmann 1998) and eustatic sea level curves of Johnson et al. (1985; see also Haq \& Schutter 2008). In the early Emsian faunule of our section in the Tafilalt, we found a decrease in benthic species with a simultaneous increase in infaunal palaeotaxodont bivalves, which are tolerant to low oxygen conditions. This fact in combination with limonitised fossils and the sediments consisting of greenish claystone documents a less oxygenized sea floor than in the Pragian. This decline in oxygen content at the sea floor could have been triggered by a transgression during the early Zlíchovian (Kröger 2008, Lubeseder et al. 2009) that possibly correlates with the transgressive cycle Ib sensu Johnson et al. (1996).

Our analysis of the earliest Lochkovian to early Emsian faunules (according to Bultynck \& Walliser 2000b) of the Taouz area did not show a macroecological change similar to the "Devonian nekton revolution" (Klug et al. 2010). Demersal and planktonic species were predominant and were not significantly displaced by nektonic organisms such as acanthodian and ammonoids through time. The geological range and time span studied here limit the comparison of our results with the diversity changes that occurred during the "Devonian nekton revolution" (Klug et al. 2010); this is linked with the fact that faunule compositions were examined here on a regional level only and some important changes might have occurred within the Emsian, perhaps between "faunule 1" and "faunule 2" (Zlíchovian, early Emsian) of Klug et al. (2008a). However, the "faunule 2" of Klug et al. (2008a) in our section did not yield many fossils and it reflects only geographically limited changes in palaeoecology.

\section{Systematic palaeontology}

Phylum Mollusca Linnaeus, 1758

Class Amphigastropoda Simroth, 1906

Family Bellerophontidae M'Coy, 1851

Subfamily Cymbulariinae Horný, 1963

\section{New genus aff. Coelocyclus Perner, 1903}

Remarks. - Horný (1963) established the new Subfamily Cymbulariinae within the Family Bellerophontidae, inclu- 
ding four genera: Cymbularia Koken, 1896, Ptychosphaera Perner, 1903, Prosoptychus Perner, 1903, and Coelocyclus Perner, 1903. However, since his work of 1963, no revision of this widely distributed group has been published.

\section{New genus aff. Coelocyclus sp. nov.} Figure 9AC-AE

Material. - One shell (PIMUZ 30604) from the Pragian of Jebel Oaoufilal in the Tafilalt (Morocco), housed in the Paläontologisches Institut und Museum der Universität Zürich.

Remarks. - Only a single shell is available, which resembles species of the genus Coelocyclus Perner, 1903. However, its very sharp circumbilical ridge and very low whorl profile differ from the morphological range of Coelocyclus. These distinct shell features suggest a position close to Coelocyclus but probably in an independent genus.

Occurrence. - Only one specimen from Jebel Ouaoufilal (Filon 12) in the Tafilalt of Morocco is known.

\section{Class Gastropoda Cuvier, 1797}

Remarks. - Family-level classification of Bouchet et al. (2005) is used in the following sections.

Family ?Oriostomatidae Wenz, 1938

\section{Genus Oriomphalus Horný, 1992a}

Type species. - Oriomphalus puellarum Horný, 1992a; Pragian, Early Devonian; basal part of Loděnice Limestone, Praha Formation, Prague Basin, Czech Republic.

Remarks. - Horný (1992a) placed two Early Devonian species, Oriomphalus puellarum Horný, 1992a and O. supraliratus (Rohr \& Smith 1978), within the new genus Oriomphalus. $O$. supraliratus, was described from the Lochkovian beds of the Canadian Arctic Islands and was originally placed within the genus Cyclonema (Cyclonema) Hall, 1852 by Rohr \& Smith (1978). The type species Oriomphalus puellarum Horný, 1992a comes from the basal part of the Loděnice Limestone (Praha Formation, Pragian, middle Early Devonian) of the Prague Basin. Later, Frýda \& Manda (1997) reported the occurrence of another species, $O$. aff. O. puellarum, from the Monograptus uniformis graptolite Biozone (early Lochkovian). The higher systematic position of the genus Oriomphalus is still uncertain because of the lack of data on its protoconch morphology. Judging from teleoconch morphology, it probably belongs to the archaeogastropod lineage and close to the genus Australonema Tassell, 1980.

\section{Oriomphalus multiornatus sp. nov.} Figure 9A-O

Holotype. - The holotype (PIMUZ 30598) is figured in Fig. 9M-O and is housed in the Paläontologisches Institut und Museum der Universität Zürich.

Type horizon and locality. - Pragian, pireneae Zone; Seheb El Rhassel Group, Jebel Ouaoufilal (Filon 12), Tafilalt, Morocco.

Material. - Seven shell fragments (PIMUZ 30587, PIMUZ 30594-30598) from the Jebel Ouaoufilal in the eastern Tafilalt, Morocco.

Etymology. - Multiornatus, combination of multi (much) and ornatus (decorated).

Diagnosis. - The species of Oriomphalus is ornamented with several distinct spiral threads crossed by dense collabral threads at early shell whorls and a wide pleural angle.

Description. - Description is based on all specimens (PIMUZ 30587, PIMUZ 30594-30598). Species with a small, turbiniform shell having at least seven whorls; whorl profile slightly shouldered in early whorls and rounded in later whorls; whorl profile between the sutures strongly convexly arched; sutures distinctly impressed; pleural

Figure 9. Pragian gastropods from the Jebel Ouaoufilal in the eastern Tafilalt. • A-O - Oriomphalus multiornatus gen. et sp. nov.; A-C - apical, lateral and basal views of the shell, $\times 2$; PIMUZ 30594. D, E - apical and apertural views, $\times 2$; PIMUZ 30595. F-I - apical, apertural, lateral and basal views, $\times 2$; PIMUZ 30596. J, K - apical and apertural views, $\times 2$; PIMUZ 30597. M-O - apical, apertural and lateral views, $\times 2$; PIMUZ 30598. P-U - Australonema sp. nov. P, R - apical, apertural and basal views, $\times 2$; PIMUZ 30599. S-U - apical, apertural and basal views, $\times 2$; PIMUZ 30600. V, W - ?Spirina sp.; dor-

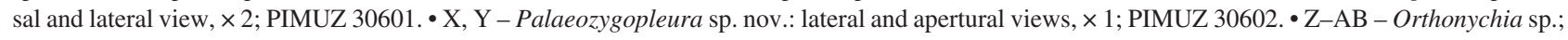
apertural, lateral, dorsal views, $\times 1$; PIMUZ 30603. • AC-AE - new genus aff. Coelocyclus sp. nov.; apertural, lateral and dorsal views, $\times 1$; PIMUZ 30604. • AF-AH - aff. Tychobrahea Horný, 1992a; apical, lateral and basal views, × 2; PIMUZ 30605. • AI-AN - Rihamphalus gracilis (葆a, 1938); AI, AK - apical, lateral and basal views, $\times 1$; PIMUZ 30606; AL-AN - apical, apertural and basal views, $\times 2$; PIMUZ 30607. $\bullet$ AO, AP - Paraoehlertia sp.; apical and lateral views, $\times 3$; PIMUZ 30608. $\bullet$ AQ-AT - Eohormotomina restisevoluta gen. et sp. nov.; AQ, AR - apical and lateral views, $\times 3$; PIMUZ 30609; AS, AT - apical and lateral views, × 3; PIMUZ 30610. • AU, AV - Umbotropis sp.; apical and lateral views, $\times 1$; PIMUZ 30611. 
Linda Frey et al. • Diversity and palaeoecology of Early Devonian invertebrate associations in the Tafilalt
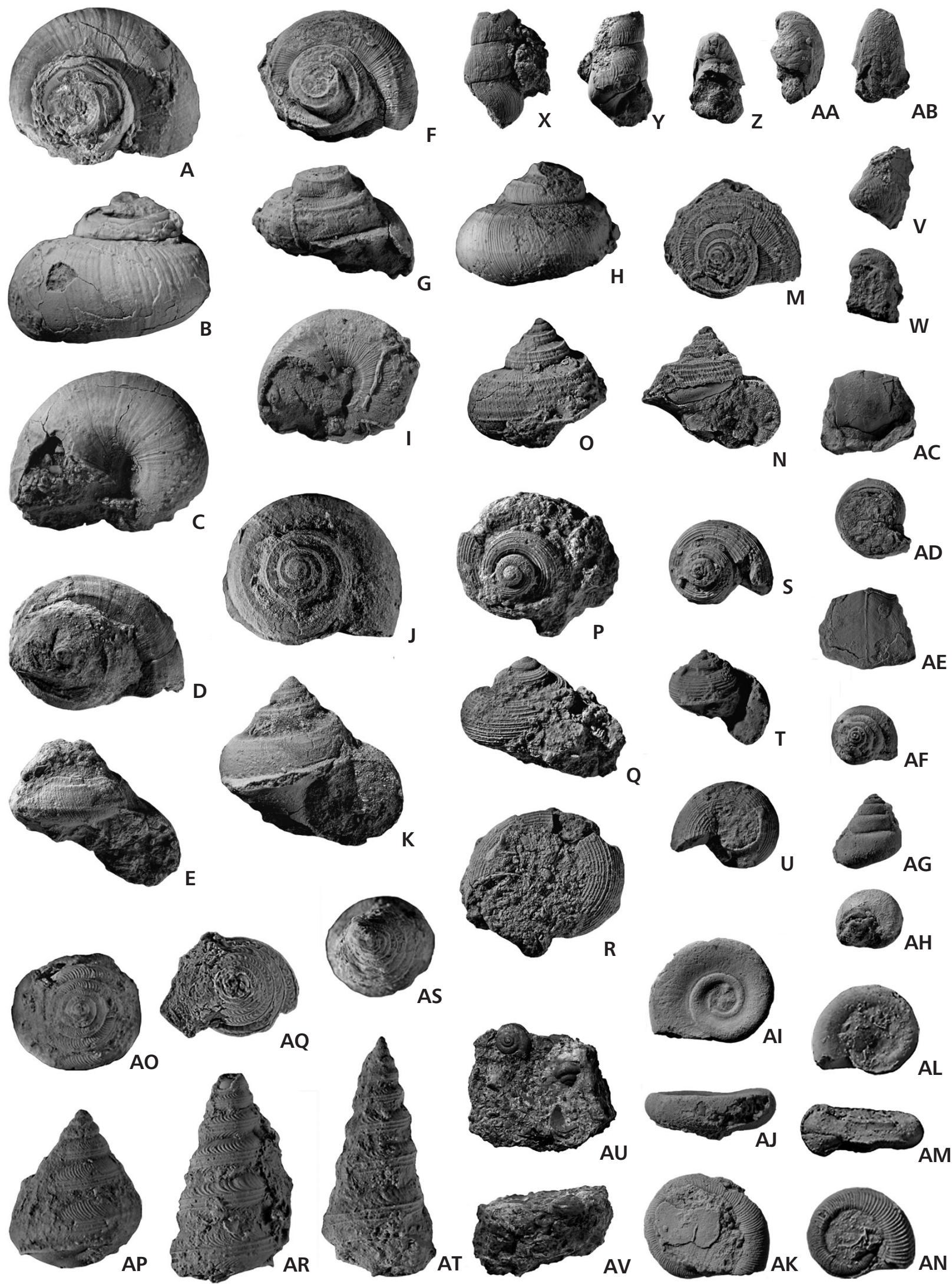
angle is about $90^{\circ}$; early whorls slightly shouldered; adult whorls rounded; shell base narrowly phaneromphalous. Shell ornamentation consists of several distinct spiral threads, only on the upper and median portion of the whorl crossed by collabral threads in early shell whorls. The spiral threads are crossed by more or less regularly spaced, dense, collabral threads, which are always weaker than the stronger spiral threads of young whorls; the spiral threads disappear on more adult whorls; circumbilical thread present on all whorls. The protoconch is unknown.

Remarks. - The shell of Oriomphalus multiornatus gen. et sp. nov. differs from all known species of the genus, such as the Pragian O. puellarum and the Lochkovian O. supraliratus as well as $O$. aff. puellarum, by a much wider pleural angle. In addition, it has a more distinct shell ornamentation than $O$. puellarum and $O$. aff. puellarum; it is also more shouldered in early whorls (compare with Horný 1992a, pl. I, figs 5-8 as well as Frýda \& Manda 1997, pl. 8, figs 6,7$)$. The Lochkovian $O$. supraliratus has a much higher shell and less prominent collabral threads than O. multiornatus gen. et sp. nov.

Occurrence. - The species is only known from the locality Jebel Ouaoufilal in the eastern Tafilalt, Morocco.

\section{Genus Australonema Tassel, 1980}

Type species. - Cyclonema australis Etheridge, 1890; Pragian, Cave Hill Quarries, Lilydale Limestone Formation, Australia.

Remarks. - Tassell (1980) established the new genus Australonema for gastropods with numerous, closely spaced spiral elements of ornamentation and placed it within the Subfamily Gyronematinae Knight, 1956 of the Family Holopeidae Wenz, 1938. Tassell (1980) described and transferred six species from Early Silurian to Early Devonian strata of Australia to the genus Australonema. He also suggested the replacement of the Wenlockian Cyclonema carinatum var. multicarinatum Lindström, 1884 to Australonema. Later, Gubanov \& Yochelson (1994) described an additional new species of Australonema, namely $A$. varvarae from the Wenlockian of Siberia. The same authors also questioned the higher taxonomy of Australonema and noted a similarity of this genus to Oriostoma MunierChalmas, 1876. Gubanov \& Yochelson (1994) pointed out that the presence of a shallow but distinct umbilicus in Oriostoma distinguishes Australonema from the latter genus. However, as shown by Tassell (1980), the shells of Australonema species including the type species A. australis (Etheridge, 1890), also have a well developed umbilicus. Yochelson \& Linsley (1972) described and illustrated a specimen of Cyclonema lilydalensis Etheridge, 1891 (= A. lilydalensis) with an in situ paucispiral operculum. A paucispiral operculum was also found in the Wenlockian A. varvarae Gubanov \& Yochelson, 1994 and by Horný (1998), in the Pragian A. cf. guillieri (Oehlert, 1881). Recently, two new species were described from the Prague basin: A. blodgetti Frýda \& Manda, 1997 from the Monograptus uniformis graptolite Biozone (early Lochkovian) and A. havliceki Frýda \& Bandel, 1997, from the uppermost part of the Trrebotov Limestone (Daleje-Třebotov Formation, lowermost Eifelian).

\section{Australonema sp. nov.}

Figure 9P-U

Material. - Two shells (PIMUZ 30599-30600) from the Pragian of the Jebel Ouaoufilal in the Tafilalt (Morocco), housed in the Paläontologisches Institut und Museum der Universität Zürich.

Remarks. - The specimens of Australonema sp. nov. clearly belong to the genus Australonema. This species differs from all known Devonian species of Australonema by a very low spire. However, the limited material and the preservation do not suffice to introduce a new species.

Occurrence. - Only two specimens have been found which are limited to the southern Tafilalt in Morocco.

Family Eotomariidae Wenz, 1938

\section{Genus Paraoehlertia Frýda, 1998a}

Type species. - Paraoehlertia parva Frýda, 1998a; earliest Eifelian, Middle Devonian; uppermost part of the Třebotov Limestone, Daleje-Třebotov Formation, Prague Basin, Czech Republic.

Remarks. - The genus Paraoehlertia differs from the closely related genus Oehlertia in its wide periselenizone area, minutely phaneromphalous base, and opisthocline apertural margin below the selenizone. The genus Paraoehlertia unites several, hitherto undescribed species from the Lower Devonian of Europe. The archaeogastropod protoconch type (Frýda 1998a) in the type species places this genus within the Subclass Archaeogastropoda.

\section{Paraoehlertia sp.}

Figure 9AO, AP

Material. - A single specimen (PIMUZ 30608) with nicely 
preserved ornamentation (PIMUZ X) from the Jebel Ouaoufilal in the eastern Tafilalt (Morocco).

Remarks. - Only a single shell is available. However, its well-preserved ornamentation shows all diagnostic characters of the genus Paraoehlertia. Ongoing revision of the Early Devonian gastropods from Europe and Australia (by Jiří Frýda) revealed several already described species of Paraoehlertia that were placed in different eotomariid genera. Species-level placement of the Moroccan Paraoehlertia will be possible after finishing the ongoing revisions.

Family Gosseletinidae Wenz, 1938

\section{Genus Umbotropis Perner, 1903}

Type species. - Umbotropis albicans Perner, 1903; Lower Devonian; Prague Basin, Czech Republic.

Remarks. - The type species Umbotropis albicans Perner, 1903 comes from the Lower Devonian of the Prague Basin. Knight (1941) designated the holotype as derived from the specimens shown by Perner (1903) in figs 6, 7 on pl. 42 from the neighbourhood of the village Měn̆any. The type horizon of this species is not clearly established but it probably comes from limestones of Pragian age. Another Pragian species of the genus U. rihai Frýda \& Manda, 1997, was described from the Prague basin. Besides these species, the Emsian U. mesoni Tassell, 1982 from the "Receptaculites" Limestone of Australia is the only further species of this genus.

\section{Umbotropis sp.}

Figure 9AU, AV

Material. - Two shells (PIMUZ 30611) from the Jebel Ouaoufilal in the Tafilalt (Morocco).

Remarks. - Both shells from the Jebel Ouaoufilal in the Tafilalt clearly display generic features of the genus Umbotropis. The lack of additional shell characters (because of their weathered surface) does not allow their determination on the species level.

Family Murchisonidae Koken, 1896

Genus Eohormotomina gen. nov.

Type species. - Eohormotomina restisevoluta gen. et sp. nov.; Pragian, Early Devonian; Jebel Ouaoufilal (Filon 12), Tafilalt, Morocco.
Etymology. - Eohormotomina, using the combination of Eos (= dawn) and the generic name Hormotomina.

Diagnosis. - A high-spired murchisoniid with selenizone bearing a medial spiral cord and bordered by two spiral cords. Selenizone situated at midwhorl height; whorl surface above and below selenizone bears prominent collabral, strongly prosocline costae forming a deep sinus.

Remarks. - The genus Eohormotomina is very close to the genus Hormotomina Grabau \& Shimer, 1909, based on Murchisonia maia Hall, 1861, from the Columbus Limestone (Eifelian) of Ohio. In contrast to Hormotomina, the shell of the Pragian Eohormotomina restisevoluta gen. et sp. nov. is ornamented with distinct collabral costae and has a wider pleural angle. The shell of Eohormotomina also resembles Parahormotomina sibertae Blodgett, Frýda \& Racheboeuf, 1999, from the Kersadiou Formation (middle Givetian) in the vicinity of Brest (Brittany, northwestern France). Eohormotomina differs from Parahormotomina by the absence of two spiral cords, one just above, and the other slightly below the suture. By the absence of a distinct spiral cord below its selenizone and distinct collabral costae, Parahormotomina differs from the genus Bouskaspira Frýda 1999, which is based on the Pragian species Aclisina fugitiva Perner, 1907.

\section{Eohormotomina restisevoluta $\mathrm{sp}$. nov.} Figure 9AQ-AT

Holotype. - Shell fragment (PIMUZ 30609) is figured in Fig. 9AQ, AR. Paläontologisches Institut und Museum der Universität Zürich.

Type horizon and locality. - Pragian, pireneae Zone; Seheb El Rhassel Group, Jebel Ouaoufilal (Filon 12), Tafilalt, Morocco.

Material. - The holotype (PIMUZ 30609) and a second shell fragment (PIMUZ 30610) were collected from the Jebel Ouaoufilal in the Tafilalt.

Etymology. - From restis (Latin) - rope and evolutus (Latin) - enrolled; referring to the superficial resemblance to an enrolled pile of rope.

Diagnosis. - See generic diagnosis.

Description. - Description is based on all specimens (PIMUZ 30609-30610). Specimens with high spired shells with at least nine whorls; spiral angle about 30 degrees. Selenizone raised, forming whorl periphery, situated at midwhorl height, whorl profile above selenizone distinctly 
convex; selenizone bordered by prominent spiral cords and bearing a prominent median cord; width of selenizone about one third of the distance between sutures; upper spiral cord of selenizone slightly above mid-whorl height; whorl profile below selenizone flat on spiral whorls, gently rounded on final whorl; whorl surface above and below selenizone bears prominent collabral, strongly prosocline costae forming a deep sinus. The initial part of shells is unknown.

Remarks. - Horný (1992b) noted the occurrence of a single shell fragment from the Loděnice Limestone (Pragian) of Bohemia, which shows diagnostic features of Hormotomina Grabau \& Shimer, 1909 and might represent the oldest evidence for this genus. However, the shell surface of this poorly preserved fragment bears traces of distinct prosocline cords as in Eohormotomina restisevoluta gen. et sp. nov. Therefore, it is possible that the shell fragment from the Loděnice Limestone belongs to our newly described genus Eohormotomina.

Occurrences. - The species has been found in the Tafilalt (Morocco) and is suspected to occur in the Loděnice Limestone of the Barrandian area (Czech Republic).

Family ?Euomphalidae de Koninck, 1881

\section{Genus Rihamphalus Frýda, 1998b}

Type species. - Porcellia gracilis Ř́ha, 1938; Pragian, Early Devonian; Prague Basin, Czech Republic.

Remarks. - Ǩíha (1938) placed his newly described species within the genus Porcellia Léveillé and noted its similarity to the Silurian species $P$. sinistrorsa Perner, 1903. However, $P$. sinistrorsa has a sinistrally coiled shell with a dis-

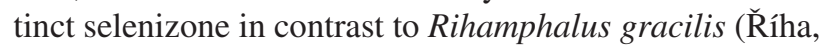
1938). Frýda (1997) placed P. sinistrorsa within the new genus Pernericirrus of the Family Porcelliidae, which unites shells with dextral coiling in the early whorls and sinistral or planispiral coiling in the later whorls of the teleoconch (Frýda \& Blodgett 1998). The shell of $R$. gracilis (̌̌íha, 1938) bears characteristic features of members of the Family Euomphalidae. Nevertheless, diagnostic features of the Euomphalidae, such as the shape of the protoconch, were not hitherto documented in Rihamphalus, and so its higher taxonomic position is uncertain.

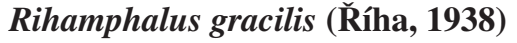

Figure 9AI-AN

Material. - Five shell fragments (PIMUZ 30588, PIMUZ
30606-30607) were collected from the Jebel Ouaoufilal in the eastern Tafilalt of Morocco.

Remarks. - All shell features of the shells coming from the locality Jebel Ouaoufilal fit well to those of the type species Rihamphalus gracilis. The genus was previously only known from the Prague basin. Ongoing revision of the Early Devonian gastropods of Australia (by Jiří Frýda) revealed another undescribed species of the genus Rihamphalus.

Occurrence. - The species is known from the Prague Basin in the Czech Republic and the Tafilalt in Morocco.

Superfamily Loxonematoidea Koken, 1889 Family Palaeozygopleuridae Horný, 1955

\section{Genus Palaeozygopleura Horný, 1955}

Type species. - Zygopleura alinae Perner, 1907; Pragian, Early Devonian; Dvorce-Prokop Limestone, Praha Formation, Prague Basin, Czech Republic.

Remarks. - Devonian species of this genus were recorded from Europe, North America, Australia, and Africa. Blodgett et al. (1988, 1990) showed an Old World Realm distribution of Palaeozygopleura, which most probably arose in the Rhenish - Bohemian Region of the Old World Realm, where the majority of the Early Devonian species and also the oldest species of this genus occur (Frýda 1993, Frýda \& Blodgett 2004, Frýda et al. in press). Ongoing revision of the Early Devonian gastropods from Europe and Australia (by Jiří Frýda) revealed about ten hitherto undescribed species of Palaeozygopleura.

\section{Palaeozygopleura sp. nov.}

Figure 9X, Y

Material. - 14 shell fragments (PIMUZ 30589, PIMUZ 30602) from the Pragian of the Jebel Ouaoufilal in the Tafilalt (Morocco). The specimens are housed in the Paläontologisches Institut und Museum der Universität Zürich.

Remarks. - The fragments found between the Jebel Ouaoufilal and Filon 12 bear distinct shell characters, which allows placing them doubtlessly to the genus Palaeozygopleura. Judging from the fragment size, this species is probably the biggest of all Palaeozygopleura species and by this character, it resembles a hitherto undescribed species from the Pragian of France. However, the shape of its asymmetric arched costae (Fig. 9X, Y) differs from the species found in France. The Moroccan specimens belong to a new species of Palaeozygopleura, but incomplete shells (i.e., fragments formed 
only by two whorls) prevent to establish a new species. Beside this new Moroccan species, the only other African species of Palaeozygopleura is P. vaneki Frýda, Ferrová, Berkyová, and Frýdová, 2008, reported by De Baets et al. (2010) from early Emsian strata of Morocco.

Occurrence. - The new species is restricted to the Tafilalt of Morocco.

Class Cephalopoda Cuvier, 1797

Order Pseudorthocerida Barskov, 1963

Family Spyroceratidae Shimizu \& Obata, 1935

\section{Genus Cancellspyroceras Kröger, 2008}

Type species. - Orthoceras loricatum Barrande, 1868 by subsequent designation; Pragian Lower Devonian; lower part of the Dvorce-Prokop Limestone, Bohemia, Czech Republic.

\section{Cancellspyroceras loricatum (Barrande, 1868) Figure 10A, B}

Material. - Six fragments of phragmocones (PIMUZ 30590, PIMUZ 30612) from the Jebel Ouaoufilal, Tafilalt, Morocco. PIMUZ 30612 with injury and with overgrowth of Filihernodia buccina Taylor \& Wilson gen. et sp. nov.

Diagnosis. - See Kröger (2008).

Description. - The maximum observed length of the largest fragment (PIMUZ 30612) is $264 \mathrm{~mm}$. The widest conch diameter is $73.9 \mathrm{~mm}$ at the most abapical chamber and the smallest conch diameter is $30.5 \mathrm{~mm}$ at the most adapical chamber. Slightly cyrtoconic shell, angle of expansion approx. $11^{\circ}$. Ornamented shell with longitudinal and transverse lirae. Irregular distance between transverse lirae, longitudinal lines and transverse lirae become narrower from the abapical to the adapical part of the fragment. At a diameter of $49.4 \mathrm{~mm}$, the ornamentation is interrupted by a big injury (height: $11.9 \mathrm{~mm}$; width: $42.5 \mathrm{~mm}$ ).

Occurrence. - Cancellspyroceras loricatum has been reported from the Pragian, Czech Republic and Morocco.

Family Pseudorthoceratidae Flower \& Caster, 1935

\section{Genus Geidoloceras Kröger, 2008}

Type species. - Geidoloceras ouaoufilalense Kröger, 2008, original designation; Pragian, Early Devonian; Filon 12, Tafilalt, Morocco.
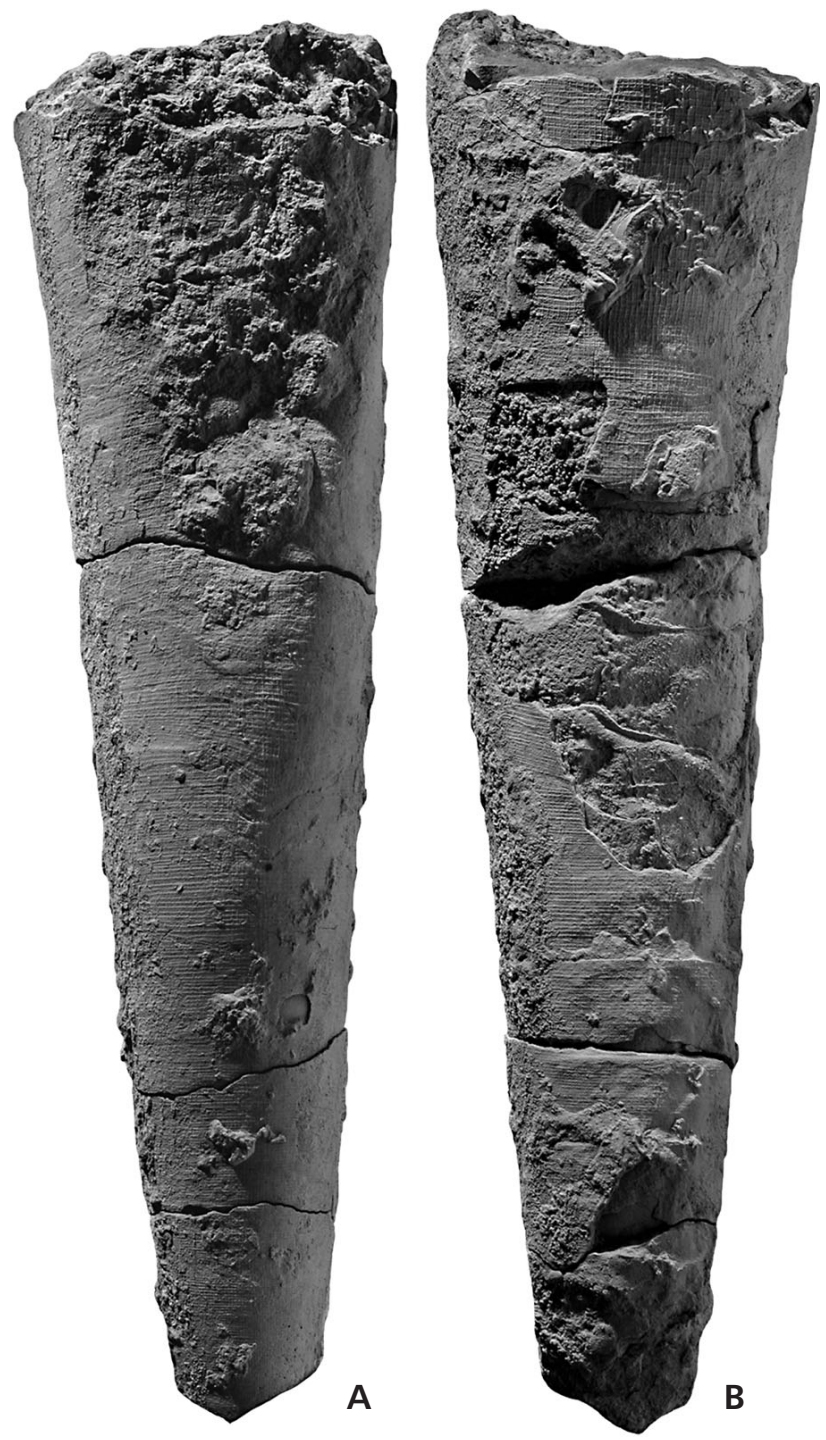

Figure 10. Large fragment of a Pragian nautiloid from the Jebel Ouaoufilal in the Tafilalt. - A, B - Cancellspyroceras loricatum (Barrande, 1868); lateral views of phragmocone fragment, $\times 0.5$; PIMUZ 30612.

\section{Geidoloceras ouaoufilalense Kröger, 2008} Figure 11G, H

Holotype. - The specimen MB.C.9627 is housed in the Museum für Naturkunde Berlin.

Type horizon and locality. - Pragian; bed KMO-II, Filon 12 section, Tafilalt, Morocco.

Material. - 24 fragments of phragmocones (PIMUZ 30591, PIMUZ 30616) from Jebel Ouaoufilal, Tafilalt, Morocco.

Diagnosis. - Emended after Kröger (2008): Orthoconic or 
slightly cyrtoconic shell with almost circular conch cross-section, angle of expansion approx. $10-12^{\circ}$. Shell ornamentation with transverse, narrow ridges. Siphuncle subcentral, expanding within the chambers, cyrtochoanitic septal necks.

Description. - The length of the phragmocone fragment PIMUZ 30616 is $31.5 \mathrm{~mm}$ with an orthoconic shell. Maximum observed conch diameter $20.4 \mathrm{~mm}$, minimum observed conch diameter $16.4 \mathrm{~mm}$, angle of expansion approx. $12^{\circ}$. Shell ornamentation with oblique transverse narrow ridges, 6 ridges per $1 \mathrm{~mm}$. Three chambers are fully preserved; septal distance of the three abapical chambers is $5.5 \mathrm{~mm}$ and $4.8 \mathrm{~mm}$ of the two adapical chambers. Siphuncle subcentral; distance of the third septum (aboral) from the margin of the conch $9.3 \mathrm{~mm}$ on the dorsal side and $7.9 \mathrm{~mm}$ on the ventral side. Siphuncle tube expands within chambers, largest expansion of the connecting ring measures $3.4 \mathrm{~mm}$. Short septal necks cyrtochoantic, diameter of septal perforation $1.7 \mathrm{~mm}$.

Occurrence. - The species is restricted to the Pragian in the Tafilalt in Morocco.

\section{Genus Subdoloceras Kröger, 2008}

Type species. - Subdoloceras tafilaltense Kröger, 2008; Pragian, Early Devonian; Filon 12, Tafilalt, Morocco.

\section{Subdoloceras atrouzense Kröger, 2008}

Figure 11I-L

Holotype. - Specimen MB.C.9595 in the Museum für Naturkunde Berlin.
Type horizon and locality. - Pragian; bed KMO-II, Filon 12 section, Tafilalt, Morocco.

Material. - 46 phragmocones (PIMUZ 30592, PIMUZ 30617-30618) from Jebel Ouaoufilal, Morocco, Pragian.

\section{Diagnosis. - See Kröger (2008).}

Description. - The length of the orthocone fragment PIMUZ 30617 is $28.7 \mathrm{~mm}$. Orthoconic conch, conical shape, and circular conch cross-section. Maximum conch diameter is $14.5 \mathrm{~mm}$ at the adoral site and minimum diameter is $6.3 \mathrm{~mm}$ at the aboral side, angle of expansion approx. $15^{\circ}$. Shell ornamented with 10 fine transverse ridges, straight. Septal distance is $2.0 \mathrm{~mm}$ at the most adoral chamber and $1.2 \mathrm{~mm}$ at the most aboral chamber. Siphuncle subcentral and thin.

Occurrence. - The species is restricted to the Tafilalt of Morocco.

Order Orthoceratida Kuhn, 1940

Family Orthoceratidae M'Coy, 1844

Tenuitheoceras gen. nov.

Type species. - Tenuitheoceras secretum gen. et sp. nov., designated herein; Pragian, Early Devonian; Jebel Ouaoufilal (Filon 12), Tafilalt, Morocco.

Diagnosis. - Slender, orthoconic shell shape with compressed cross-section. Ornamented shell with faint oblique transverse striae. Angle of expansion $6^{\circ}$, narrow septal dis-

Figure 11. Phragmocone fragments of Lochkovian and Pragian nautiloids from the Jebel Ouaoufilal in the Tafilalt. • A, B - Pseudendoplectoceras lahcani Kröger, 2008; lateral and septal views, fragments of the phragmocone, $\times 1$; PIMUZ 30613. • C, D - Endoplectoceras sp.; lateral views, phragmocone with shell remains, $\times 2$; PIMUZ 30614. • E, F - Tafilaltoceras adgoi Kröger, 2008; lateral and septal views, phragmocone incrusted by tabulate coral and crinoids, $\times 1$; PIMUZ 30615. • G, H - Geidoloceras ouaoufilalense Kröger, 2008; lateral view and longitudinal section of an incomplete phragmocone, $\times 1$; PIMUZ 30616. • I-M - Subdoloceras atrouenze Kröger, 2008; I, J - lateral views of phragmocone fragment with epizoans, $\times$ 1.5; PIMUZ 30617; K-M - lateral and septal views of phragmocone with epizoans and machaerid fragment, $\times 1.5$; PIMUZ 30618 . - N, O - Subdoloceras engeseri Kröger, 2008; lateral views of phragmocone fragment, $\times 1$; PIMUZ 30619. • P - Spyroceras cyrtopatronus Kröger, 2008; lateral view of phragmocone fragment, $\times 1.5$; PIMUZ 30620. • Q - Spyroceras patronus (Barrande, 1866); lateral view of phragmocone fragment, $\times$ 1.5; PIMUZ 30621. • R - Spyroceras latepatronus Kröger, 2008; lateral view of phragmocone fragment, $\times 1.5$; NHMUK PI BZ 7494. - S-U - Arthrophyllum vermiculare (Termier \& Termier, 1950); S - lateral view of phragmocone fragment, $\times 1.5 ;$ PIMUZ 30623; T - lateral view of phragmocone with tabulate coral, $\times 1.5$; PIMUZ 30624; U - longitudinal section of phragmocone, $\times 1$; PIMUZ 30625. • V, W - Orthocycloceras tafilaltense Kröger, 2008; lateral and septal views of phragmocone, $\times 1.5$; PIMUZ 30626. $\bullet$ X-Z - Tenuitheoceras secretum gen. et sp. nov.; longitudinal section and lateral views of phragmocone, $\times 1.5$; PIMUZ 30627. • AA, AB - Adiagoceras sp.; lateral views of phragmocone, $\times 1$; PIMUZ 30628 . - AC, AD - Arionoceras kennethdebaetsi sp. nov.; longitudinal section and lateral view of phragmocone fragment, $\times 1$; PIMUZ 30629 . - AE, AF - Angeisonoceras reteornatum Kröger, 2008; lateral and septal view of phragmocone, $\times 1$; PIMUZ 30630. • AG - Anaspyroceras sp.; lateral view of phragmocone fragment, $\times 1.5$; PIMUZ 30631. $\bullet$ AH-AJ - Harrisoceras sp.; lateral and septal views of phragmocone fragment, $\times 1.5$; PIMUZ 30632. AK - Plagiostomoceras culter (Barrande, 1866); lateral view of the mould of the body chamber and several phragmocone chambers, $\times 1$; PIMUZ 30633. • AL-AM - Plagiostomoceras sp.; lateral views of phragmocone fragment, $\times 1.5$; PIMUZ 30634. • AN-AO - Hemicosmorthoceras sp.; lateral views of phragmocone fragment, $\times 1.5$; PIMUZ 30635. 
Linda Frey et al. • Diversity and palaeoecology of Early Devonian invertebrate associations in the Tafilalt

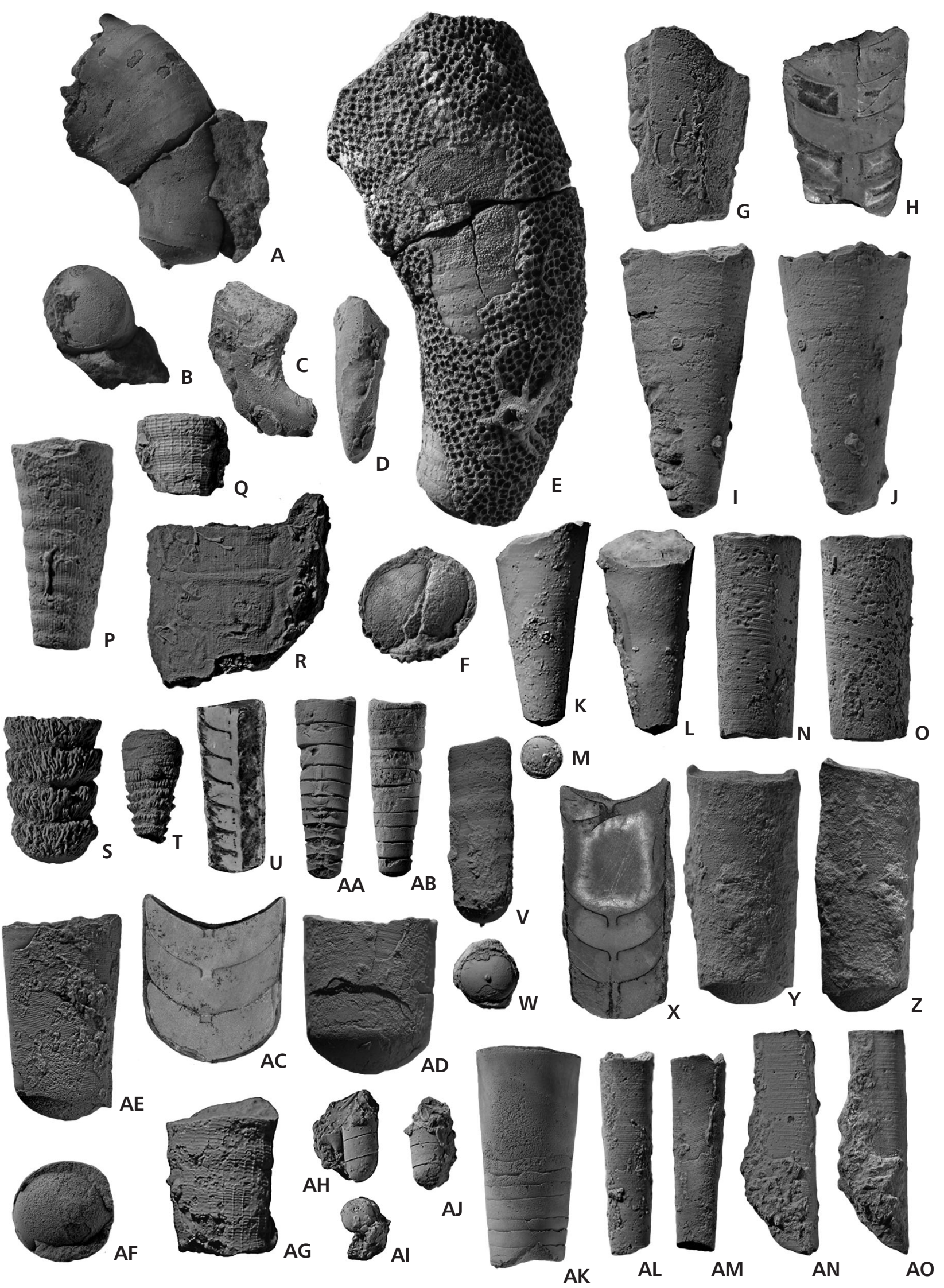


tance approx. 0.3 of the conch cross-section. Siphuncle subcentral, long septal necks approx. 0.3 of the septal distance, orthochoanitic. Diameter of septal perforation approx. 0.1 of conch diameter.

Etymology. - After the similar genus Theoceras Kröger, 2008 and tenuis (Latin) - narrow, referring to the compressed cross section.

Remarks. - The genus Tenuitheoceras is similar to Theoceras Kröger, 2008 in having a slender, orthoconic conch and narrow septal distances. It differs in having a compressed conch cross-section, relatively long septal necks and a subcentral siphuncle instead of an eccentric siphuncle as in Theoceras. Moreover, the septal necks of the new genus do not form a funnel.

Included species. - Only the type species.

\section{Tenuitheoceras secretum sp. nov.} Figure 11X-Z

Holotype. - The specimen in Fig. 11X-Z, PIMUZ 30627 , Paläontologisches Institut und Museum der Universität Zürich.

Type horizon and locality. - Pragian, pireneae Zone; Seheb El Rhassel Group, Jebel Ouaoufilal (Filon 12), Tafilalt, Morocco.

Material. - Holotype: phragmocone fragment (PIMUZ 30627) from Jebel Ouaoufilal (Filon 12), Tafilalt, Morocco.

Etymology. - Secretum (Latin) - clandestine, secret, lurking: referring to the fact that this species did not reveal its traits superficially.

Diagnosis. - See generic diagnosis.

Description. - The holotype PIMUZ 30627 measures $28.7 \mathrm{~mm}$. Slender and orthoconic shape with compressed conch cross-section with the maximum diameter of $13.3 \mathrm{~mm}$, angle of expansion approx. $6^{\circ}$. Shell ornamented with 4 faint transverse striae per $1 \mathrm{~mm}$. Three chambers are well preserved; the maximum distance between two septa is $4.3 \mathrm{~mm}$ in the most adapical chamber and the smallest distance $3.9 \mathrm{~mm}$ in the second chamber. Siphuncle subcentral with distances of $5.8 \mathrm{~mm}$ dorsal and $4.9 \mathrm{~mm}$ ventral from the conch margin. Septal necks are orthochoanitic, relatively long, length of the longest septal neck $1.4 \mathrm{~mm}$ in the most adapical chamber. Diameter of septal perforation is $1.1 \mathrm{~mm}$.
Occurrence. - Only the holotype from the Tafilalt of Morocco is known.

Family Arionoceratidae Dzik, 1984

\section{Genus Arionoceras Barskov, 1966}

Type species. - Orthoceras canonicum Meneghini, 1857 by subsequent designation; Wenlock, Silurian; Cea di San Antonio, Fluminimaggiore, Sardinia, Italy.

\section{Arionoceras kennethdebaetsi sp. nov. \\ Figure 11AC, AD}

Holotype. - The phragmocone fragment PIMUZ 30629 (Fig. 11AC, AD), Paläontologisches Institut und Museum der Universität Zürich.

Type horizon and locality. - Pragian, pireneae Zone; Seheb El Rhassel Group, Jebel Ouaoufilal (Filon 12), Tafilalt, Morocco.

Material. - Only the holotype (PIMUZ 30629) from the Jebel Ouaoufilal (Filon 12), Tafilalt, Morocco.

Etymology. - Species named after the Kenneth De Baets, honouring his contributions to research on Palaeozoic cephalopods.

Diagnosis. - Orthoconic conchs with circular conch cross-section. Shell ornamentation with transverse striae is forming a deep sinus. Angle of expansion approx. $6^{\circ}$, septal distance approx. 0.34 of the conch diameter. Siphuncle central, short septal necks approx. 0.23 of the septal distance, suborthochoanitic. Diameter of septal perforation approx. 0.1 of conch cross-section, bigger than length of septal necks.

Description. - The maximum fragment length of the holotype (PIMUZ 30629) is $27.5 \mathrm{~mm}$. Orthoconic conch, circular cross-section with the largest diameter $24.8 \mathrm{~mm}$, angle of expansion approx. $6^{\circ}$. Fine transverse striae form a deep sinus, 4 striae per $1 \mathrm{~mm}$, sutures straight. Three chambers are preserved, the highest septal distance measures $8.0 \mathrm{~mm}$ in the two most adapical chambers. Siphuncle central, small septal necks, suborthochoanitic, $1.8 \mathrm{~mm}$ long, septal perforation $2.2 \mathrm{~mm}$ in diameter.

Remarks. - Arionoceras kennethdebaetsi sp. nov. resembles A. capillosum Barrande, 1867 in having a similar angle of expansion, the same chamber/conch diameter ratio, the same septal perforation/conch diameter ratio and septal 
neck morphology. But A. kennethdebaetsi sp. nov. differs from $A$. capillosum in having a much deeper sinus. The newly described species has been found in the Pragian stage and is the youngest Arionoceras species of Morocco so far.

Occurrence. - Only the holotype from the Tafilalt of Morocco is known.

Family Geisonoceratidae Zhuravleva, 1959

\section{Genus Angeisonoceras Kröger, 2008}

Type species. - Orthoceras davidsoni Barrande, 1870; Upper Silurian; Lochkov, Bohemia, Czech Republic.

\section{Angeisonoceras reteornatum Kröger, 2008 Figure 11AE, AF}

Holotype. - The specimen MB.C.9946 is in the Museum für Naturkunde Berlin.

Type horizon and locality. - Pragian; bed KMO-II, Filon 12 section, Tafilalt, Morocco.

Material. - 11 phragmocone fragments (PIMUZ 30593, PIMUZ 30630) from the Pragian, Jebel Ouaoufilal, Tafilalt, Morocco.

Diagnosis. - See Kröger (2008).

Description. - The phragmocone fragment PIMUZ 30630 is $35.0 \mathrm{~mm}$ long, orthoconic, slightly acuminate, with a circular conch cross-section. The maximum diameter at the most abapical part of the phragmocone is $19.9 \mathrm{~mm}$; the minimum diameter at the most adapical septum is $17.8 \mathrm{~mm}$, angle of expansion approx. $5^{\circ}$. Ornamented shell with 5 oblique transverse ridges per $1.0 \mathrm{~mm}$, interrupted by smooth longitudinal striae. Five chambers are preserved with a measurable septal distance of $5.7 \mathrm{~mm}$ at the most adapical chamber. Siphuncle subcentral, with a siphuncle diameter of $2.0 \mathrm{~mm}$ at the adapical part of the fragment.

Occurrence. - The species is only known from the Tafilalt of Morocco.

Order Oncocerida Flower, in Flower \& Kummel (1950) Family Nothoceratidae Fischer, 1882

\section{Genus Tafilaltoceras Kröger, 2008}

Type species. - Tafilaltoceras adgoi Kröger, 2008 by origi- nal designation; Pragian, Early Devonian; Filon 12, Tafilalt, Morocco.

Tafilaltoceras adgoi Kröger, 2008

Figure 11E, F

Holotype. - Specimen MB.C.9634, Museum für Naturkunde Berlin.

Type horizon and locality. - Pragian; bed KMO-I, Filon 12 section, Tafilalt, Morocco.

Material. - 1 phragmocone fragment (PIMUZ 30615) from Jebel Ouaoufilal, Tafilalt, Morocco.

Diagnosis. - Emended after Kröger (2008): Cyrtoconic shell expanding with slightly depressed conch crosssection; angle of expansion approx. 12 to $14^{\circ}$. Straight septa; slightly concave. Siphuncle marginally, at the convex side of the shell; siphuncular diameter approx. 0.1 of conch cross-section, suborthochoantic septal necks, diameter of septal perforation approx. 0.16 of conch diameter.

Description. - Phragmocone fragment PIMUZ 30615 is $85.0 \mathrm{~mm}$ long with cyrtoconic shell and slightly oval conch cross-section. The maximum observed conch diameter measures $39.4 \mathrm{~mm}$ and the smallest diameter $19.5 \mathrm{~mm}$, angle of expansion is approx. $14^{\circ}$. Shell ornamentation is not visible, because the specimen is completely encrusted by tabulate corals and a crinoid holdfast (Fig. 11E). 20 chambers are preserved, which display straight sutures; the smallest septal distance at the most adapical chamber is $2.9 \mathrm{~mm}$ and the largest septal distance at a diameter of $30.8 \mathrm{~mm}$. Siphuncle on the convex side of the conch, siphuncle diameter $3.0 \mathrm{~mm}$ at the aboral side and $4.9 \mathrm{~mm}$ at the adoral side.

Remarks. - The shell ornamentation of Tafilaltoceras adgoi is still uncertain. The holotype found by Kröger (2008) and our new specimen (PIMUZ 30615) are extremely encrusted by epizoans. The species is emended with regard to the variability of the angle of expansion. In contrast to the holotype (angle of expansion: $12^{\circ}$ ), the new material reveals an angle of expansion of $14^{\circ}$.

Occurrence. - Pragian, Tafilalt, Morocco.

Phylum Echinodermata Klein, 1734

Class Crinoidea Miller, 1821

Subclass Camerata Wachsmuth \& Springer, 1885

Order Monobathrida Moore \& Laudon, 1943

Suborder Compsocrinina Ubaghs, 1978 
Superfamily Hexacrinitacea Wachsmuth \& Springer, 1885 Family Hexacrinitidae Wachsmuth \& Springer, 1885

\section{Hexawacrinus gen. nov.}

Type species. - Hexawacrinus claudiakurtae gen. et sp. nov., designated herein; Pragian, Early Devonian, Jebel Ouaoufilal (Filon 12), Tafilalt, Morocco.

Definition of genus. - Monocyclic calyx with conical shape, smooth plates, 3 basals in the first row, 6 plates (5 radials and 1 anal plate?) in the second row. Length of basals approx. 0.6 of radial lengths, hexagonal. The radials are the biggest plates, heptagonal and hexagonal plates are alternating. The following primibrachs are smaller than basals and radials, approx. 0.48 of the size of the radials, hexagonal, higher in width than in length. The branches are connected to the primibrachs, contact point on the primibrachs is weakly developed. Two rows of interprimibrachs, small, second row interprimibrachs are the smallest plates, hexagonal. Sutures between plates are strongly developed.

Remarks. - The new genus differs from Hexacrinites Austin \& Austin, 1843 in lacking contact points for branches at the anterior parts of the radials. The specimen shows some affinity to Wacrinus caseyensis Jell \& Jell, 1999. The sequence of the basals, radials, primibrachs and interprimibrachs is the same. Moreover, in both species, the contact points for the branching sclerites are situated at the same position, namely at the anterior parts of the primibrachs. However, the proportions of the plates strongly differ (e.g. basals are bigger and reach a higher level) and the plates are more symmetric than in Wacrinus. The general calyx shape is rather conical than subspherical.

Included species. - Only the type species.

\section{Hexawacrinus claudiakurtae sp. nov. Figure $12 \mathrm{E}-\mathrm{G}$}

Holotype. - The specimen (PIMUZ 30636) is figured in
Fig. 12E, F and is housed in the Paläontologisches Institut und Museum der Universität Zürich.

Type horizon and locality. - Pragian, pireneae Zone; Seheb El Rhassel Group, Jebel Ouaoufilal (Filon 12), Tafilalt, Morocco.

Material. - The calyx fragment PIMUZ 30636 has been found at the Jebel Ouaoufilal in the eastern Tafilalt of Morocco.

Etymology. - The species is named after the finder Claudia Kurt (Basel), who kindly donated the specimen.

Diagnosis. - As for genus.

Description. - The calyx fragment PIMUZ 30636 is $13.0 \mathrm{~mm}$ long and $12.6 \mathrm{~mm}$ wide and has a slightly conical shape. All three basal plates are hexagonal and of similar shape and size. Their length is in between $3.6 \mathrm{~mm}$ and $3.8 \mathrm{~mm}$ and reach approx. 0.6 of the length of the following radial plates. Their maximum width is between $5.9 \mathrm{~mm}$ and $6.1 \mathrm{~mm}$. In the second row, just three plates are completely preserved. They are the biggest plates of the calyx with similar size: length: 5.5 to $5.9 \mathrm{~mm}$; width: 5.0 to $5.5 \mathrm{~mm}$; they have an alternating heptagonal or hexagonal shape. All of them might be affiliated to radials. Two primibrachs are visible that are following two different radials. They are $2.4 \mathrm{~mm}$ in length and $3.9 \mathrm{~mm}$ in width, symmetric and hexagonal. They abut radials and interprimibrachs. One of the primibrachs shows a slight concave depression at the anterior margin and might be a potential contact point for a secundibrach. Two interprimibrachs on the first level are present. They are 2.9 to $3.3 \mathrm{~mm}$ long and 2.9 to $3.4 \mathrm{~mm}$ wide, hexagonal, slightly smaller than the primibrachs. Their margins abut radials, primibrachs and two interprimibrachs on the second level. Just two second row interprimibrachs are preserved. They are the smallest plates of the fragment, hexagonal and symmetric, $1.8 \mathrm{~mm}$ long and $1.9 \mathrm{~mm}$ wide.

Occurrence. - A single specimen of Pragian age has been found at the Jebel Ouaoufilal in the eastern Tafilalt of Morocco. Other occurrences are not known.

Figure 12. Hederelloids, crinoids, tabulate and rugose corals from the Pragian of the Jebel Ouaoufilal in the Tafilalt. • A-D - Filihernodia buccina gen. et sp. nov. Taylor \& Wilson; A - large colony on a nautiloid, $\times 2$; PIMUZ 30612; B-D - detail views of a small colony on a nautiloid, produced by a scanning electron microscope (SEM), B × 20 and C, D × 40; NHMUK PI BZ 7494. • E-G - Hexawacrinus claudiakurtae gen. et sp. nov.; lateral and basal views of calyx fragment, $\times 2$; PIMUZ 30636. $\bullet$ H - Tiaracrinus moravicus Ubaghs \& Bouček, 1962; lateral view of the radial plate of the calyx, $\times 2$; PIMUZ 30637. • I, J - Cleistopora cf. geometrica Milne-Edwards \& Haime, 1851; view on three corallites and bottom, $\times 1$; PIMUZ 30638 . - K, L - Proclevia sp.; view on corallites and bottom side, $\times 1$; PIMUZ 30639. • M-O - Favositidae Dana, 1846; M - lateral view, $\times 1$; PIMUZ 30640; $\mathrm{N}, \mathrm{O}-$ top and lateral view, $\times 1$; PIMUZ 30641. $\bullet$ P, Q - unidentified tabulate coral; top and bottom view, $\times 1$; PIMUZ 30642. $\bullet$ R - Aulopora sp.; small corallites on a hyolithid, $\times 2$; PIMUZ 30643. $\bullet \mathrm{S}-$ unidentified rugose coral; lateral view on a corallite, $\times 1.5 ;$ PIMUZ 30644 . 
Linda Frey et al. • Diversity and palaeoecology of Early Devonian invertebrate associations in the Tafilalt
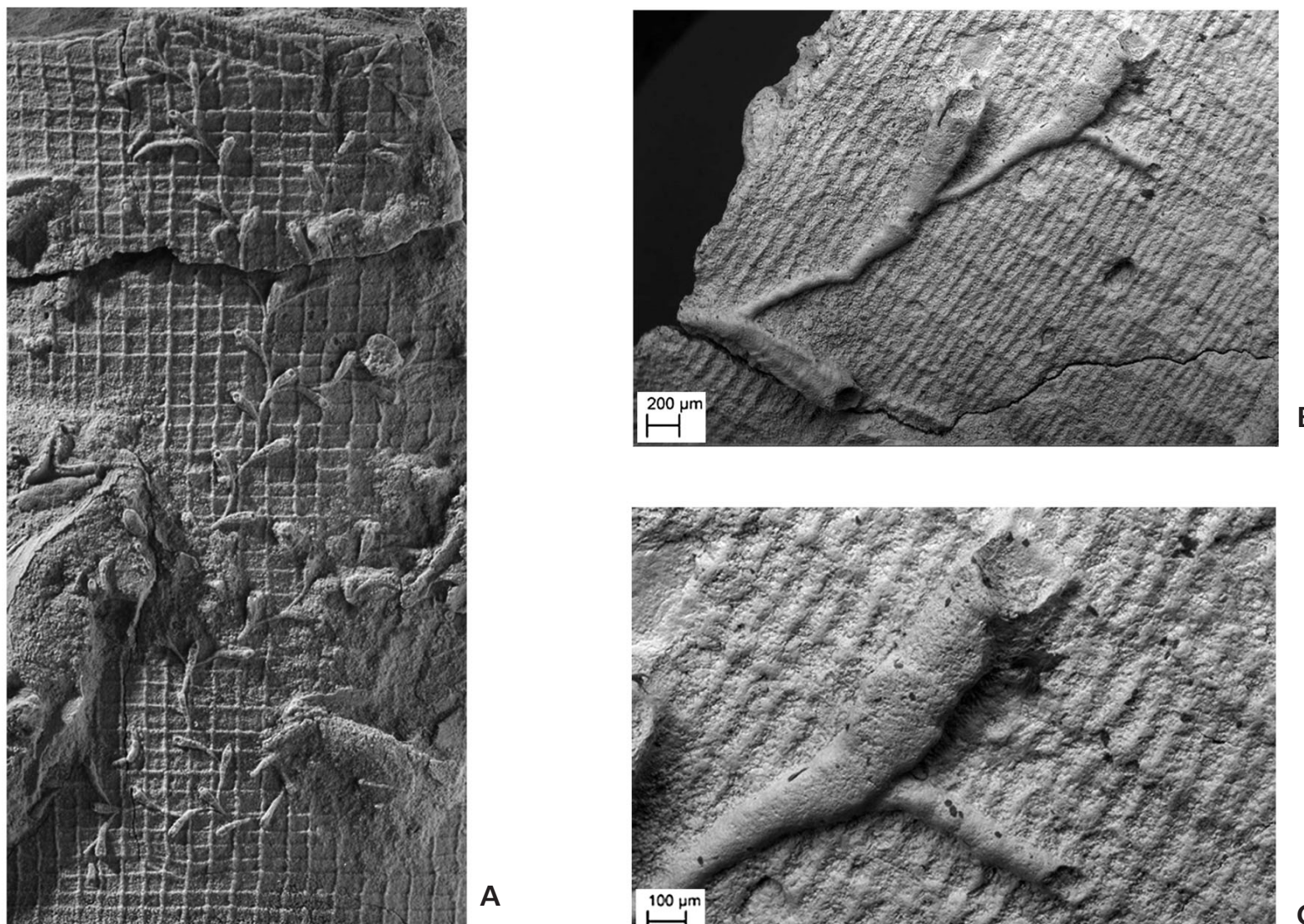

B

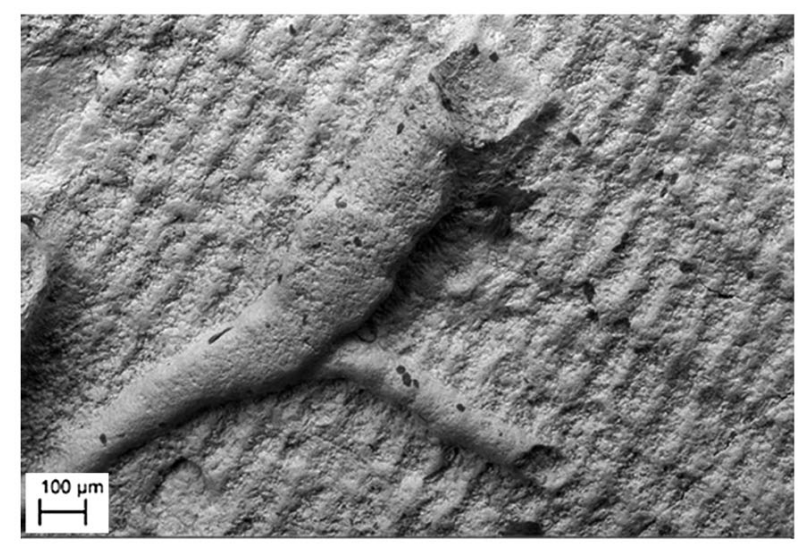

C
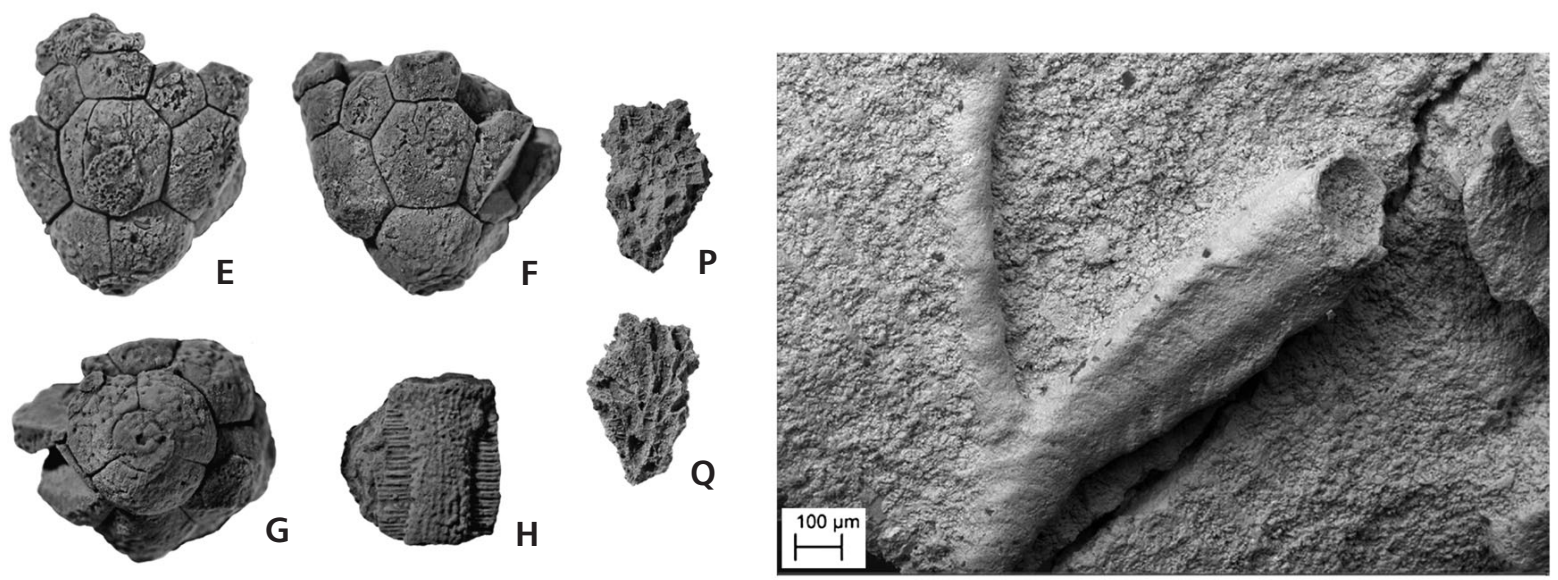

D
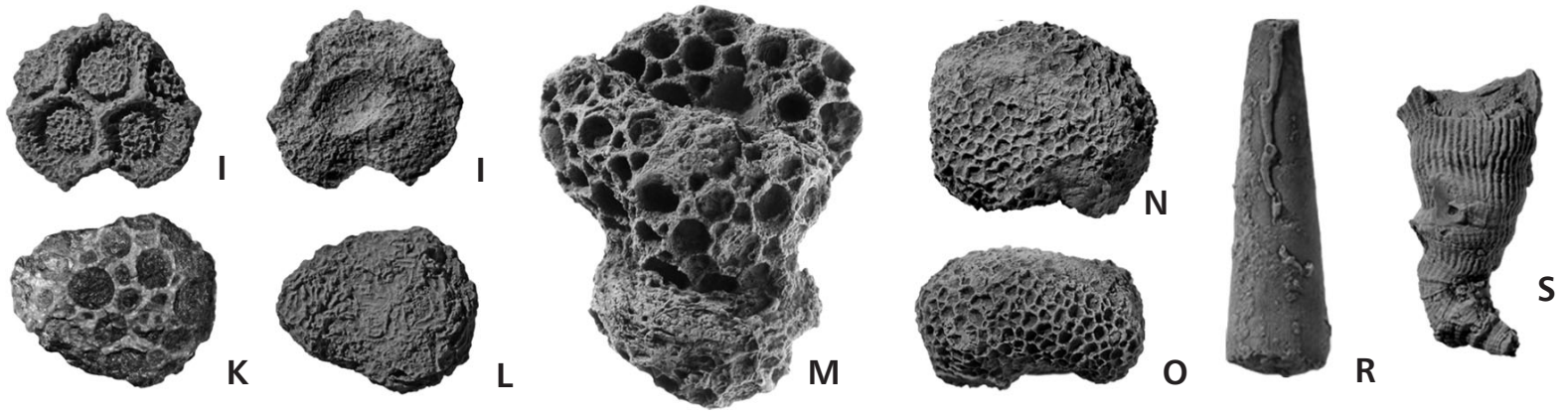
Subclass Disparida Moore \& Laudon, 1943

Order Cladida Moore \& Laudon, 1943

Suborder Compsocrinina Ubaghs, 1978

Superfamily Belemnocrinacea S.A. Miller, 1892

Family Zophocrinidae S.A. Miller, 1892

\section{Genus Tiaracrinus Schultze, 1866}

Type species. - Tiaracrinus quadrifrons Schultze, 1866; Eifelian, Middle Devonian; Freilingen Formation, Nollenbach Member, Eifel, Germany.

\section{Tiaracrinus moravicus Ubaghs \& Bouček, 1962} Figure 12H

Holotype. - Specimen BR 362, stored in the National Museum of Prague, Czech Republic.

Type horizon and locality. - Emsian, Lower Devonian; Plumlov, Moravia, Czech Republic.

Material. - A cup fragment (PIMUZ 30637) collected from the Jebel Ouaoufilal, Tafilalt, Morocco.

Diagnosis. - After Hauser (2008): Elongate conical calyx, with reduced, longitudinally oval radial rib field, 4 oval radials with epispiral ridges and grooves and bulging threepart radial ring.

Description. - The maximum length of the fragment PIMUZ 30637 is $7.8 \mathrm{~mm}$ and the maximum width is $6.4 \mathrm{~mm}$. The radial is large, has an ornamented surface displaying irregular ridges and bulges; its outline is rectangular to slightly oval in shape, slightly convex with epispiral ridges and grooves at the margins. There are 13 deep and 12 shallow grooves alternating regularly on the right side of the radial. On the left side, 14 deep grooves and 8 smaller grooves are visible. The radial becomes distally wider and displays 4 weak ridges.

Remarks. - In contrast to the type material, the here described new material, which consist of one radial plate, preserves the skeletal material and thus the surface ornamentation. The assignment to Tiaracrinus moravicus is based on the shape of the radial with the oval radial rib fields and the broad radial channels. Between the radial rib fields, the sclerite's surface displays an ornamentation of fine ribs, tubercles and nodes. In this respect, it resembles T. oehlerti, which has been suggested to be conspecific by Hauser (2008) and as sister species by Klug et al. (2013). Since the new Moroccan material displays the morphology of the outside of the radial, it can now be concluded that (1) T. moravicus and T. oehlerti are not conspecific and should be kept as separate species, (2) the two species are indeed sister species, which (3) is now corroborated by the coeval occurrence of the two species, which are clearly older than four other species of Tiaracrinus (T. rarus, T. jeanlemenni, T. tetraedra, T. quadrifrons). The here described new specimen represents the first record of $T$. moravicus from Africa.

Occurrence. - An Emsian specimen has been found in Plumlov, Moravia, Czech Republic and a Pragian specimen is here described from the Jebel Ouaoufilal, Tafilalt, Morocco.

Phylum Incertae sedis Suborder Hederelloidea Bassler, 1939

Remarks. - Hederelloids are among the most common encrusting sclerobionts on Devonian hard substrates. Although traditionally considered as cyclostome bryozoans (e.g., Bassler 1953 in the bryozoan Treatise), they differ from cyclostomes and bryozoans in several important respects. Notably, hederelloid walls have a prismatic microstructure and the zooids are often larger than those found in any unequivocal bryozoans. Taylor \& Wilson (2008) reconsidered the affinities of these colonial animals, noting similarities in zooidal budding pattern to that of the colonial phoronid worm Phoronis ovalis. Despite the lack of a mineralized skeleton in recent phoronids, the resemblance led these authors to hypothesize that hederelloids were an extinct (Silurian-Permian) clade of colonial phoronids that evolved calcified skeletons.

Family Reptariidae Simpson, 1897

\section{Genus Filihernodia Taylor \& Wilson gen. nov.}

Type species. - Filihernodia buccina gen. et sp. nov. Taylor \& Wilson; Pragian, Early Devonian; Jebel Ouaoufilal (Filon 12), Tafilalt, Morocco.

Etymology. - Alluding to its similarity with Hernodia Hall, 1881 , but having zooids that are very narrow proximally, hence fili from filum meaning "thread, string, filament, fibre".

Genus definition. - Hederelloid with horn-shaped zooids originating as narrow buds mid-way along the lengths of parent zooids, alternately on the left and right sides, except at branch bifurcations, where a pair of daughter zooids is present, one on each side of the parent; new buds diverge at about $60^{\circ}$ from parent zooids and broaden distally. 
Remarks. - Five genera of hederelloids are currently recognized (Taylor \& Wilson 2008). This new genus most closely resembles Hernodia but differs in having zooids that are very narrow proximally and broad distally, whereas the zooids of Hernodia have a uniform width. Indeed, the threefold increase in width along the zooids of Filihernodia is an unusual attribute among hederelloids as a whole. Furthermore, slender zooids of Filihernodia rapidly separate from their parent zooids, giving the colony a more gracile morphology than Hernodia in which daughter zooids diverge at low angles and tend to adhere to the sides of their parents for some distance before separating. The longitudinal ridges visible on the surfaces of some zooids of Filihernodia are lacking in other hederelloids, where transverse growth bands tend to be better developed.

Included species. - Only the type species.

\section{Filihernodia buccina sp. nov. Taylor \& Wilson} Figure 12A-D

Holotype. - The specimen (PIMUZ 30612) is figured in Fig. 12A, and is housed in the Paläontologisches Institut und Museum der Universität Zürich.

Type horizon and locality. - Pragian, pireneae Zone; Seheb El Rhassel Group, Jebel Ouaoufilal (Filon 12), Tafilalt, Morocco.

Material. - Holotype: PIMUZ 30612 (large colony in Zurich). Paratype: NHMUK PI BZ 7494 (small specimen scanned at the NHM) in Fig. 12B, C. Both specimens have been found at the Jebel Ouaoufilal (Filon 12) in the Tafilalt of Morocco.

Etymology. - Buccina, L. for shepherd's horn, in reference to the shape of the zooids.

Diagnosis. - As for genus.

Description. - Colony (NHMUK PI BZ 7494) encrusting, uniserial, runner-like, comprising slender, gently sinuous, bifurcating branches formed of zooids budded approximately mid-length on the side of a zooid from the preceding generation, alternately to the left and the right and diverging at up to $60^{\circ}$. Branch bifurcation is infrequent, arising from budding of paired daughter zooids on the two opposite sides of a parent zooid, which is straighter than normal, the two branches diverging initially at about $90^{\circ}$. Early astogeny is unknown.

Zooids tubular, horn-shaped, curved through an angle of up to about $45^{\circ}$, narrow proximally, gradually broadening distally towards the terminal aperture. Total zooid length $2.5-3.5 \mathrm{~mm}$, proximal width about $0.12-0.14 \mathrm{~mm}$, distal width $0.38-0.46 \mathrm{~mm}$. Walls non-porous, marked by faint transverse growth lines and up to three, low longitudinal ridges in some zooids. Aperture is subcircular and about $0.26-0.28 \mathrm{~mm}$ in diameter.

Remarks. - As noted above, this new genus and species most closely resembles Hernodia, which Bassler (1939) distinguished from other hederelloids on the basis of its elongate, club-shaped zooids budding alternately from about the middle of the sides of the preceding zooids. Bassler (1939) described eight species of Hernodia from the Silurian-Devonian of the United States, noting two further species from the Silurian and Devonian of Bohemia. One named and one questionable species of Hernodia were subsequently described from the Devonian of Germany (Solle 1952, 1968).

Compared to species of Hernodia, F. buccina has colonies of a more gracile appearance, with long, narrow zooids that diverge from their parent zooids at relatively high angles. Species such as H. tennesseensis Bassler, 1935 and H. concinna Bassler, 1935, by contrast, have low angles of bud divergence, resulting in the new buds being aligned subparallel and often initially adherent to the parent zooid. In terms of zooid size, $F$. buccina is most similar to H. davisi Bassler, 1935 from the Hamilton Group of the Falls of the Ohio, but zooids of this species maintain an almost constant width along their lengths.

Occurrence. - The species is only known from the Pragian of the Jebel Ouaoufilal in the Tafilalt (Morocco).

\section{Acknowledgements}

We greatly appreciate the support by the Swiss National Science Foundation (Project No. 200021-113956/1, 200020-25029, and 200020-132870). Jens Koppka (Porrentruy) kindly checked our determinations of the trilobites. Joachim Hauser (Bonn) helped with the determination of the new crinoid species. We thank the students of the University of Zurich who joined the palaeontological fieldwork course 2012 in Morocco and helped to collect the fossil material included in the study. Participation of Jiří Frýda was supported by the Grant Agency of the Czech Republic (P210/12/2018).

\section{References}

Alberti, G.K.B. 1969. Trilobiten des jüngeren Siluriums sowie des Unter- und Mitteldevons; I. Mit einigen Beiträgen zur Silur-Devon Stratigraphie einiger Gebiete Marokkos und Oberfrankens. Abhandlungen der Seckenbergischen naturforschenden Gesellschaft 520, 1-692.

AlBerti, G.K.B. 1980. Neue Daten zur Grenze Unter-/Mittel- 
Devon, vornehmlich aufgrund der Tentaculiten und Trilobiten im Tafilalt (Marrokko). Neues Jahrbuch für Geologie und Paläontologie, Monatshefte 1980, 581-594.

AlberTi, G.K.B. 1981. Daten zur stratigraphischen Verbreitung der Nowakiidae (Dacryoconarida) im Devon von NW-Afrika (Marokko, Algerien). Senckenbergiana lethaea 62, 205-216.

Alberti, G.K.B. 1983. Trilobiten des jüngeren Siluriums sowie des Unter- und Mittel-Devons; IV. Senckenbergiana lethaea 61(1), 1-87.

Ausich, W.I. \& BotTJER, D.J. 1982. Tiering in suspension-feeding communities on soft substrata throughout the Phanerozoic. Science New Series 216(4542), 173-174.

Austin, T. \& Austin, T. JR. 1843. A Description of several new genera and species of Crinoidea. Annals and Magazine of Natural History (series 1) 11(69), 195-207.

BARRANDE, J. 1846. Notice préliminaire sur le systême silurien et les trilobites de Bohême. 86 pp. Hirschfeld, Leipzig. DOI 10.5962/bhl.title.9141, DOI 10.5962/bhl.title.9142

BARRANDE, J. 1866. Système silurien du centre de la Bohême, I. Partie, Vol. II: Céphalopodes 2. Pl. 108-244. Privately published, Prague \& Paris.

BARRANDE, J. 1867. Système silurien du centre de la Bohême, I. Partie, Vol. II: Céphalopodes 1.712 pp. Privately published, Prague \& Paris.

BARRAnde, J. 1868. Système silurien du centre de la Bohême, I. Partie, Vol. II: Céphalopodes 3. Pl. 245-350. Privately published, Prague \& Paris.

Barrande, J. 1870. Système silurien du centre de la Bohême, I. Partie, Vol. II: Céphalopodes 4. Pl. 351-460. Privately published, Prague \& Paris.

BarRande, J. 1881. Système silurien du centre de la Bohême. Classe des Mollusques, ordre des Acéphalés 6. 342 pp. Privately published, Prague \& Paris.

BARskov, I.S. 1963. System and phylogeny of the Pseudorthoceratids. Byulleten Moskovskogo obshchevestva ispytatelei prirody, Otdel geologicheskii 38(4), 149-150.

BARSKov, I.S. 1966. Cephalopods of the Late Ordovician and Silurian of Kazakhstan and Middle Asia. Autoreferat dissertatcii na soiskanie utchenoyi stepeni kandidata geologicheskii mineralogicheskii nauka. 200 pp. Izdatel'stvo Moskovskogo Universiteta, Moscow.

BASSLER, R.S. 1935. Bryozoa (generum et gentyporum index et bibliographia). Fossilium Catalogus. I: Animalia Pars 67, $1-229$.

BASSLER, R.S. 1939. The Hederelloidea, a suborder of Paleozoic cyclostomatous Bryozoa. Proceedings of the United States National Museum 87, 25-91. DOI 10.5479/si.00963801.87-3068.25

BAssler, R.S. 1953. Bryozoa, G1-G253. In Moore, R.C. (ed.) Treatise on Invertebrate Paleontology, Part G. Geological Society of America and University of Kansas Press, Lawrence.

Becker, R.T. \& House, M.R. 1994. International Devonian goniatite zonation, Emsian to Givetian, with new records from Morocco. Courier Forschungsinstitut Senckenberg 169, 79-135.

BeCKER, R.T. \& House, M.R. 2000. Emsian and Eifelian ammonoid succession at Bou Tchrafine (Tafilalt platform, Anti-Atlas, Morocco), 21-26. In El Hassani, A. \& TAhiri, A. (eds) Moroccan meeting of the Subcommision on Devonian
Stratigraphy (SDS) - IGCP 421 Excursion Guidebook, Notes et Mémoirs du Service Géologique 399.

Belka, Z., Kaufmann, B. \& Bultynck, P. 1997. Conodont-based quantitative biostratigraphy for the Eifelian of the eastern Anti-Atlas, Morocco. Geological Society of American Bulletin 109, 643-651. DOI 10.1130/0016-7606(1997)109<0643.

Belka, Z., Klug, C., Kaufmann, B., Korn, D., Döring, S., Feist, R. \& WENDT, J. 1999. Devonian conodont and ammonoid succession of the eastern Tafilalt (Ouidane Chebbi section), Anti-Atlas, Morocco. Acta Geologica Polonica 49(1), 1-23.

Blodgett, R.B., FrÝda, J. \& Racheboeuf, P.R. 1999. Upper Middle Devonian (Givetian) gastropods from the Kersiadou Formation, Brittany, France. Journal of Paleontology 73(6), 1081-1100.

Blodgett, R.B., Rohr, D.M. \& Boucot, A.J. 1988. Lower Devonian gastropod biogeography of the Western Hemisphere, 281-294. In McMillan, N.J., Embry, A.F. \& Glass, D.J. (eds) Devonian of the World. Canadian Society of Petroleum Geologists Memoir 14(3).

Blodgett, R.B., Rohr, D.M. \& Boucot, A.J. 1990. Early and Middle Devonian biogeography, 277-284. In McKerrow, W.S. \&. Scotese, C.D. (eds) Palaeozoic Palaeogeography and Biogeography. Geological Society Memoir 12.

BotTJeR, D.J. \& Ausich, W.I. 1986. Phanerozoic development of tiering in soft substrata suspension-feeding communities. Paleobiology 12(4), 400-420.

Bouchet, P., Rocroi, J. P., Frýda, J., Hausdorf, B., Ponder, W., VAldes, A. \& Warén, A. 2005. Classification and nomenclator of gastropod families. Malacologia 47, 1-368.

Brachert, T.C., Buggisch, W., Flügel, E., Hüssner, H., Joachimski, M.M., Tourneur, F. \& Walliser, O.H. 1992. Controls of mud mound formation: the Early Devonian KessKess carbonates of the Hamar Laghdad, Anti-Atlas, Morocco. Geologische Rundschau 81, 15-44. DOI 10.1007/BF01764537

Brongniart, A. 1822. Les Trilobites, 1-65. In Brongniart, A. \& Desmarest, A.G. (eds) Histoire naturelle des crustacés fossiles, sous les rapports zoologiques et géologiques. F.G. Levrault, Paris \& Strasbourg.

Bultynck, P. \& Walliser, O.H. 2000a. Emsian to Middle Frasnian sections in the northern Tafilalt, 11-20. In El Hassani, A. $\&$ TAHIRI, A. (eds) Moroccan meeting of the Subcommision on Devonian Stratigraphy (SDS) - IGCP 421 Excursion Guidebook, Notes et Mémoires du Service Géologique 399.

Bultynck, P. \& Walliser, O.H. 2000b. Devonian boundaries in the Moroccan Anti-Atlas. Courier Forschungsinstitut Senckenberg 225, 211-226.

Bush, A.M., Bambach, R.K. \& Daley, G.M. 2007. Changes in theoretical ecospace utilization in marine fossil assemblages between the mid-Paleozoic and late Cenozoic. Paleobiology 33(1), 76-97. DOI 10.1666/06013.1

Chlupáč, I., Galle, A., Hladil, J. \& Kalvoda, J. 2000. Series and stage boundaries in the Devonian of the Czech Republic. Courier Forschungsinstitut Senckenberg 225, 159-172.

Chlupáč, I. \& Kukal, Z. 1988. Possible global events and the stratigraphy of the Palaeozoic of the Barrandian (CambrianMiddle Devonian, Czechoslovakia). Sborník geologických věd, Geologie 43, 83-146.

Chlupáč, I. \& Kukal, Z. 1996. Reflection of possible global De- 
vonian events in the Barrandian area, C.S.S.R, 169-179. In WALLISER, O.H. (ed.) Global Bio-events, a critical approach. Lecture Notes on Earth Sciences 8.

Clariond, L. 1934a. Sur le Dévonien du Tafilalet et du Maroc. Compte rendu sommaire des séances de la Société Géologique de France 1934, 5-11.

Clariond, L. 1934b. A propos d'une coupe de la région d'Erfoud. Compte rendu sommaire des séances de la Société Géologique de France 1934, 223-224.

Corriga, M.G., Corradini, C., Haude, R. \& Walliser, O.H. 2013. Upper Silurian and Lower Devonian conodonts and crinoids from the scyphocrinoid beds of southeastern Morocco, 71-72. In Lindskog, A. \& MeHLQvist, K. (eds) Proceedings of the $3^{\text {rd }}$ IGCP 591 Annual Meeting, Lund, Sweden.

Cox, L.R. 1960. Gastropoda. General characteristics of Gastropoda, I84-I169. In Moore, R.C. (ed.) Treatise on Invertebrate Paleontology, Part I, Mollusca 1. Geological Society of America \& University of Kansas Press, Boulder \& Lawrence.

CuvIER, G. 1797. Tableau élémentaire de l'histoire naturelle des animaux. 710 pp. Baudouin, Paris.

DANA, J.D. 1846. Structure and classification of zoophytes: U.S. Exploring Expedition during the years 1838-1842 under the command of Charles Wilkes, U.S.N. 7. 740 pp. Lea \& Blanchard, Philadelphia.

De Baets, K., Klug, C. \& Monnet, C. 2013. Intraspecific variability through ontogeny in early ammonoids. Paleobiology 39(1), 75-94. DOI 10.1666/0094-8373-39.1.75

De Baets, K., Klug, C. \& Plusquellec, Y. 2010. Zlíchovian faunas with early ammonoids from Morocco and their use for the correlation between the eastern Anti-Atlas and the western Dra Valley. Bulletin of Geosciences 85(2), 317-352. DOI 10.3140/bull.geosci.1172

Donovan, S.K. \& Webster, G.D. 2013. Platyceratid gastropod infestations of Neoplatycrinus Wanner (Crinoidea) from the Permian of West Timor: speculations on thecal modifications. Proceedings of the Geologists' Association.

DOI 10.1016/ j.pgeola.2013.01.004

DöRING, A. 2002. Sedimentological Evolution of the late Emsian to early Givetian carbonate ramp in the Mader (eastern AntiAtlas, SE-Morocco). 80 pp. Ph.D. thesis, Eberhard-KarlsUniversität, Tübingen, Germany.

DzıK, J. 1984. Phylogeny of the Nautiloidea. Palaeontologia Polonica 45, 1-203.

Eldredge, N. 1971. Patterns in cephalic musculature in the Phacopina (Trilobita) and their phylogenetic significance. Journal of Palaeontology 45, 52-67.

Etheridge, R. 1890. Descriptions of Upper Silurian fossils from the Lilydale Limestone, Upper Yarra District, Victoria. Records of the Australian Museum 1(1), 60-67. DOI 10.3853/j.0067-1975.1.1890.1227

EthERIDGE, R. 1891. Further descriptions of the Upper Silurian fossils from the Lilydale Limestone, Upper Yarra District, Victoria. Records of the Australian Museum 1(7), 125-130. DOI 10.3853/j.0067-1975.1.1891.1244

Ferreti, A., Gnoli, M. \& VAi, G.B. 1999. Silurian to Lower Devonian communities of Sardinia, 271-281. In Bоucot, A.J. \& Lawson, J.D. (eds) Paleocommunities - a case study from the Silurian and Lower Devonian. Cambridge University Press, Cambridge.
FISCHER, P. 1882. Manuel de conchyliologie et de paléontologie conchyliologique ou histoire naturelle des mollusques vivants et fossiles, I. Partie: Synopsis des genres, 327-418. Savy, Paris.

Flower, R.H. \& CASTER, K.E. 1935. The cephalopod fauna of the Conewango Series of the Upper Devonian in New York and Pennsylvania. Bulletins of American Paleontology 22(75), $1-74$.

Flower, R. H \& Kummel, B. 1950. A classification of the Nautiloidea. Journal of Paleontology 24, 604-616.

Fortey, R.A. \& OwEns, R.M. 1999. Feeding habits in trilobites. Palaeontology 42(3), 429-465.

DOI 10.1111/1475-4983.00080

Franchi, F., Schemm-Gregory, M. \& Klug, C. 2012. A new species of Ivdelinia Andronov, 1961 and its palaeoecological and palaeobiogeographical implications (Morocco, Givetian). Bulletin of Geosciences 87(1), 1-11.

DOI 10.3140/bull.geosci.1294

FRÖHLICH, S. 2004. Evolution of a Devonian carbonate shelf at the northern margin of Gondwana (Jebel Rheris, eastern Anti-Atlas, Morocco). 71 pp. Ph.D. thesis, Eberhard-KarlsUniversität, Tübingen, Germany.

FRÝDA, J. 1993. Oldest representative of the family Palaeozygopleuridae (Gastropoda) with notes on its higher taxonomy. Journal of Paleontology 67, 822-827.

FRÝDA, J. 1997. Oldest representatives of the superfamily Cirroidea (Vetigastropoda) with notes on their early phylogeny. Journal of Paleontology 71(5), 839-847.

FRÝDA, J. 1998a. Some new and better recognized Devonian gastropods from the Prague Basin (Bohemia). Bulletin of the Czech Geological Survey 73(1), 41-49.

FRÝDA, J. 1998b. Some new and better recognized Devonian gastropods from the Prague Basin (Bohemia): part II. Bulletin of the Czech Geological Survey 73(4), 355-363.

FRÝDA, J. 1999. Further new gastropods from the Early Devonian Boucotonotus - Palaeozygopleura Community of the Prague Basin. Journal of the Czech Geological Society 44, 317-325.

FrÝDA, J. \& BANDEL, K. 1997. New Early Devonian gastropods from the Plectonotus (Boucotonotus)-Palaeozygopleura Community in the Prague Basin (Bohemia). Mitteilungen aus dem Geologisch-Paläontologischen Institut der Universität Hamburg 80, 1-58.

FrÝDA, J. \& BlodgetT, R.B. 1998. Two new cirroidean genera (Vetigastropoda, Archaeogastropoda) from the Emsian (late Early Devonian) of Alaska with notes on the early phylogeny of Cirroidea. Journal of Paleontology 72, 265-273.

FRÝDA, J. \& BLODGETT, R.B. 2004. New Emsian (late Early Devonian) gastropods from Limestone Mountain, Medfra B-4 quadrangle, west-central Alaska (Farewell terrane), and their paleobiogeographic affinities and evolutionary significance. Journal of Paleontology 78(1), 111-132.

DOI 10.1666/0022-3360(2004)078<0111:NELEDG >2.0.CO;2

Frýda, J., Ferrová, L., Berkyová, S. \& Frýdová, B. 2008. A new Early Devonian palaeozygopleurid gastropod from the Prague Basin (Bohemia) with notes on the phylogeny of the Loxonematoidea. Bulletin of Geosciences 83(1), 93-100. DOI 10.3140/bull.geosci.2008.01.093

FrÝdA, J., FerrovÁ, L. \& FrÝdovÁ, B. 2013. Review of palaeozygopleurid gastropods (Palaeozygopleuridae, Gastropoda) 
from Devonian strata of the Perunica microplate (Bohemia), with a re-evaluation of their stratigraphic distribution, notes on their ontogeny, and descriptions of new taxa. Zootaxa 3669(4), 469-489. DOI 10.11646/zootaxa.3669.4.3

FRÝDA, J. \& MANDA, Š. 1997. A gastropod faunule from the Monograptus uniformis graptolite Biozone (Early Lochkovian, Early Devonian) in Bohemia. Mitteilungen aus dem Geologisch-Paläontologischen Institut der Universität Hamburg 80, 59-122.

GaHn, F.J. \& BAumiLleR, T.K. 2003. Infestation of Middle Devonian (Givetian) camerate crinoids by platyceratid gastropods and its implications for the nature of their biotic interaction. Lethaia 36, 71-82. DOI 10.1080/00241160310003072

GAHN, F.J. \& BAUMILLER, T.K. 2006. Using platyceratid gastropod behaviour to test functional morphology. Historical Biology 18, 397-404. DOI 10.1080/08912960600668524

García-Alcade, J., Truyóls-Massoni, M., Pardo-Alonso, M., Bultynck, P. \& CARLs, P. 2000. Devonian chronostratigraphy of Spain. Courier Forschungsinstitut Senckenberg 225, 131-144.

Grabau, A.W. \& Shimer, H.W. 1909. North American index fossils: Invertebrates 1.853 pp. New York.

Gubanov, A.P. \& Yochelson, E.L. 1994. A Wenlockian (Silurian) gastropod shell and operculum from Siberia. Journal of Paleontology 68, 486-481.

HaLl, J. 1852. Containing descriptions of the organic remains of the lower middle division of the New York system. Paleontology of New York 2, 1-362.

HaLl, J. 1861. Descriptions of new species of fossils from the Upper Helderberg, Hamilton and Chemung Groups; with observations upon previously described species. Fourteenth Annual Report of the Regents of the University of the State of New York on the condition of the State Cabinent of Natural History and the Historical and Antiquarian Collection annexed thereto, Albany, 99-109.

HALl, J. 1881. Bryozoans of the Upper Helderberg and Hamilton groups. Transactions of the Albany Institute 10, 145-197.

Hall, J. 1884. Lamellibranchiata, I. Monomyaria of the Upper Helderberg, Hamilton, Portage and Chemung Groups. New York Geological Survey, Paleontology 5(1), 1-268.

Hammer, Ø., Harper, D.A.T. \& Ryan, P.D. 2001. PAST: Palaeontological statistics software package for education and data analysis. Palaeontologia Electronica 4(1), 1-9.

HaQ, B.U. \& Schutter, S.R. 2008. A Chronology of Paleozoic Sea-Level Changes. Science 322(5898), 64-68.

DOI 10.1126/science. 1161648

Haude, R. 1992. Scyphocrinoiden, die Bojen-Seelilien im hohen Silur-tiefen Devon. Palaeontographica, Abteilung A 222, 141-187.

Haude, R. \& Walliser, O.H. 1998. Conodont-based Upper Silurian-Lower Devonian range of scyphocrinoids in SE Morocco, 94-96. In GutiérRez-MARCo, J.C. \& RÁBANo, I. (eds) Proceedings of the sixth international graptolite conference of the GWG (IPA) and the SW Iberia field meeting 1998 of the International Subcommission on Silurian Stratigraphy (ICS-IUGS). Instituto Tecnológico Geominero de España, Madrid.

HAuser, J. 2008. Revision von Tiaracrinus (Crinoidea, Cladida) aus dem Paläozoikum der Eifel und dem Sauerland
(Rheinische Schiefergebirge), Massive Armoricain (Frankreich), Böhmen (Tschechien) und Nord-Afrika (Algerien). Crinoiden des Devon, 1-8.

http://www.devon-crinoiden.de/tiaracrinus.pdf

Hollard, H. 1967. Le Dévonien du Maroc et du Sahara nord occidental. International Symposium on the Devonian System, Calgary 1, Canadian Society of Petroleum Geologists 1, 203-244.

HollaRd, H. 1974. Recherches sur la stratigraphie des formations du Dévonien moyen, de l'Emsien supérieur au Frasnien, dans le Sud du Tafilalt et dans le Ma'der (Anti-Atlas oriental, Maroc). Notes du Service géologique du Maroc 36(264), 7-68.

Hollard, H. 1981.Tableaux de Corrélation du Silurien et Dévonien de l'Anti-Atlas. Notes du Service géologique du Maroc 42(308), 23-46.

HoRnÝ, R.J. 1955. Palaeozygopleuridae nov. fam. (Gastropoda) ze středočeského devonu. Sborník Ústředního ústavu geologického, Oddíl paleontologický 21(1), 17-74.

HoRnÝ, R.J. 1963. Lower Paleozoic Bellerophontina (Gastropoda) of Bohemia. Sborník geologických věd, Paleontologie $2,57-164$.

Horný, R. 1992a. New Lower Devonian gastropod genera of Bohemia (Mollusca). Časopis Národního muzea, Řada př́rodovědná 158(1-4), 105-107.

HoRnÝ, R. 1992b. Lytospira Koken a Murchisonia (Hormotomina) Grabau et Shimer v českém spodním devonu. [Lytospira Koken and Murchisonia (Hormotomina) Grabau et Shimer in the Lower Devonian of Bohemia.] Časopis Národního muzea, Řada prírodovědná 160(1-4), 55-56.

HoRnÝ, R.J. 1998. Two additional, isolated, paucispiral gastropod opercula from the Lower Devonian Koněprusy Limestone (Bohemia, Barrandian area). Journal of the National Museum (Prague), Natural History Series 167 (1-4), 91-94.

JELL, P.A. \& JeLl, J.S. 1999. Crinoids, a blastoid and a cyclocystoid from the Upper Devonian reef complex of the Canning Basin, Western Australia. Memoirs of The Queensland Museum 43, 201-236.

Johnson, J.G., KLAPPER, G. \& ElRick, M. 1996. Devonian transgressive-regressive cycles and biostratigraphy, Northern Antelope Range, Nevada: Establishment of reference horizons for global cycles. Palaios 11, 3-14. DOI 10.2307/3515112

Johnson, J.G., Klapper, G. \& SAndberg, C.A. 1985. Devonian eustatic fluctuations in Euramerica. Geological Society of America Bulletin 96, 567-587.

DOI 10.1130/0016-7606(1985)96<567:DEFIE >2.0.CO;2

KaUfmann, B. 1998. Facies analysis, stratigraphy and diagenesis of Middle Devonian reef- and mud-mounds in the Mader (eastern Anti-Atlas, Morocco). Acta Geologica Polonica 48(1), 43-106.

KLEIN, J.T. 1734. Naturalis dispositio Echinodermatum: Accesseit Lucubratiuncula de aculeis echinorum marinorum, cum Spicilegio de belemnitis. Typis Thom. Joh. Schreiberi. DOI 10.5962/bhl.title.65731

KLUG, C. 2001. Early Emsian ammonoids from the eastern AntiAtlas (Morocco) and their succession. Paläontologische Zeitschrift 74(4), 479-515. DOI 10.1007/BF02988158

KLUG, C. 2002. Quantitative stratigraphy and taxonomy of late Emsian and Eifelian ammonoids of the eastern Anti-Atlas 
(Morocco). Courier Forschungsinstitut Senckenberg 238, $1-109$.

KLug, C. \& Korn, D. 2002. Occluded umbilicus in the Pinacitinae (Devonian) and its palaeoecological implications. The Palaeontological Association 45(5), 917-931.

Klug, C., Korn, D., Naglik, C., Frey, L. \& de Baets, K. 2013. The Lochkovian to Eifelian succession of the Amessoui Syncline (southern Tafilalt), 51-60. In BECKER, R.T., El HASSANI, A. \& TAHIRI, A. (eds) International Field Symposium "The Devonian and Lower Carboniferous of northern Gondwana", Morocco 2013.

Klug, C., Korn, D. \& Reisdorf, A. 2000. Ammonoid and conodont stratigraphy of the late Emsian to early Eifelian (Devonian) at the Jebel Ouaoufilal (near Taouz, Tafilalt, Morocco), 45-56. In TAhiri, A. \& El Hassani, A. (eds) Travaux de l'Institut Scientifique, Série Géologie \& Géographie Physique 20. Proceedings of the Subcommission on Devonian Stratigraphy (SDS) - IGCP 421 Morocco Meeting.

Klug, C., Kröger, B., Kiessling, W., Mullins, G. L., Servais, T., FrÝda, J., Korn, D. \& Turner, S. 2010. The Devonian nekton revolution. Lethaia 43, 465-477. DOI 10.1111/j.1502-3931.2009.00206.x

Klug, C., Kröger, B., Korn, D., Rücklin, M., SchemmGregory, M., De Baets, K. \& MAPes, R.H. 2008a. Ecological change during the early Emsian (Devonian) in the Tafilalt (Morocco), the origin of the Ammonoidea, and the first African pyrgocystid edrioasteroids, machaerids and phyllocarids. Palaeontographica, Abteilung A 283(4-6), 83-176.

Klug, C., Meyer, E., Richter, U. \& Korn, D. 2008b. Soft-tissue imprints in fossil and Recent cephalopod septa and septum formation. Lethaia 41, 477-492.

DOI 10.1111/j.1502-3931.2008.00100.x

KNight, J.B. 1941. Paleozoic gastropod genotypes. Geological Society of America, Special Paper 32, 1-510.

KNIGHT, J.B. 1956. New families of Gastropoda. Washington Academy of Sciences Journal 46, 41-42.

KoKen, E. 1896. Die Leitfossilien. 848 pp. Chr. Herm. Trachnitz, Leipzig.

KoKEn, E. 1889. Über die Entwicklung der Gastropoden vom Kambrium bis zur Trias. Neues Jahrbuch für Mineralogie, Geologie und Paläontologie, Beilage Band 6, 305-484.

KoninICK, L.G. DE 1881. Faune du calcaire carbonifère de Belgique, Pt. 3, Gastéropodes. Annales du Musée royal d'Histoire naturelle de Belgique, paleontological series 6, 1-170.

KŘiž, J. 1998. Recurrent Silurian-lowest Devonian cephalopod limestone of Gondwanan Europe and Perunica, 183-198. In LANDing, E. \& Johnson, M.E. (eds) Silurian cycles; linkages of dynamic stratigraphy with atmospheric, oceanic, and tectonic changes. New York State Museum Bulletin 491.

Křiž, J. 2000. Lochkovian bivalves of Bohemian type from the eastern Anti-Atlas (Lower Devonian, Morocco). Senckenbergiana lethaea $80(2), 485-523$.

KRÖGER, B. 2008. Nautiloids before and during the origin of ammonoids in Siluro-Devonian section in the Tafilalt, Anti-Atlas, Morocco. Special Papers in Palaeontology 79, $1-110$.

Kunn, O. 1940. Paläozoologie in Tabellen. 50 pp. Fischer Verlag, Jena.

LeVeiLle, C. 1835. Aperçu géologique de quelques localités très riches en coquilles sur les frontières de France et de Belgique. Mémoires de la Société géologique de France 2(1), 29-40.

LindSTRÖM, G. 1884. On the Silurian gastropoda and Pteropoda of Gotland. Kongliga Svenska Vetenskaps Akademiens Handlingar 19(6), 1-250.

Linnaeus, C. 1758. Systema Naturae per Regna Tria Naturae, secundum Classes, Ordines, Genera, Species, cum Characteribus, Differentiis, Synonymis, Locis. Tomus I. 823 pp. Laurentii Salvii, Holmiae (Stockholm).

Lubeseder, S., Redfern, J. \& Boutib, L. 2009. Mixed siliciclastic-carbonate shelf sedimentation-Lower Devonian sequences of the SW Anti-Atlas, Morocco. Sedimentary Geology 215(1-4), 13-32. DOI 10.1016/j.sedgeo.2008.12.005

Massa, D., Combaz, A. \& Manderscheid, G. 1965. Observations sur les séries siluro-dévoniennes des confins algéro-marocains $\mathrm{du}$ Sud. Notes et Mémoires, Compagnie Française des Pétroles 8, 1-188.

M'Coy, F. 1844. A synopsis of the characters of the Carboniferous Limestone fossils of Ireland. 274 pp. University Press, Dublin. DOI 10.5962/bhl.title.11559

M'Coy, F. 1851. On some new Silurian Mollusca. Annals and Magazine of History, including Zoology, Botany, and Geology, $2^{\text {nd }}$ series $7,45-63$.

Meneghini, G. 1857. Paléontologie de l'Ile Sardaigne, 53-144. In La Marmora, A. (ed.) Voyage en Sardaigne. Imprimerie Royal, Turin.

Milne-Edwards, H. \& Haime, J. 1851. Monographie des Polypiers fossiles des terrains palaeozoïques, précédée d'un tableau général de la classification des polypes. $502 \mathrm{pp}$. Gide et J. Baudry, Paris.

Miller, J.S. 1821. A natural history of the Crinoidea or lilyshaped animals, with observation on the genera Astria, Euryale, Comatula, and Marsupites. 150 pp. Bryan \& Co., Bristol.

Miller, J. 1976. The sensory fields and life mode of Phacops rana (Green, 1832). Transactions of the Royal Society of Edinburgh 69, 337-367. DOI 10.1017/S0080456800015350

Miller, S.A. 1892. North American geology and palaeontology. First appendix, 665-718. Western Methodist Book Concern, Cincinnati.

Moore, R.C. \& Laudon, L.R. 1943. Evolution and classification of Paleozoic crinoids. Geological Society of America, Special Paper 46, 1-153. DOI 10.1130/SPE46-p1

Munier-Chalmas, E. 1876. Mollusques nouveaux des terrains paléozoiques des environs de Rennes. Journal de Conchyliologie, 3e series 16, 102-109.

Neyman, A.A. 1967. Limits to the application of the 'trophic group' concept in benthic studies. Oceanology, Academy of Sciences of the USSR 7, 49-155.

OeHLERT, D. 1881. Documents pour servir à l'étude des faunes dévoniennes dans l'ouest de la France. Mémoires de la Société Géologique de France, 3 e série 2, 1-38.

PeEL, J. 1984. Faunal succession and mode of life of Silurian gastropods in the Arisaig Group, Nova Scotia. Palaeontology 21, 258-306.

Perner, J. 1903. Gastéropodes, 1-164. In Barrande, J. (ed.) Systême silurien du centre de la Bohême 4(1). Prague.

Perner, J. 1907. Gastéropodes, 1-380. In Barrande, J. (ed.) Systême silurien du centre de la Bohême 4(2). Prague. 
Piqué, A. \& Michard, A. 1989. Moroccan Hercynides: A synopsis. The Paleozoic sedimentary and tectonic evolution at the northern margin of west Africa. American Journal of Science 289, 286-330. DOI 10.2475/ajs.289.3.286

Racheboeuf, P.R. 1990. Les Brachiopodes Chonetacés dans les assemblages benthiques siluriens et dévoniens. Palaeogeography, Palaeoclimatology, Palaeoecology 81, 141-171. DOI 10.1016/0031-0182(90)90045-9

ŘíiA, A. 1938. Příspěvek k poznání nových plžů ze středočeského paleozoika. Věstník Královské České společnosti nauk, Tř́ida matematicko-přirodovědecká, 1-12.

RocH, E. 1934. Sur des phénomènes remarquables observés dans la région d'Erfoud (confins algéro-marocains du Sud). Association Études de la Géologie Méditerranéenne Occidentale 5, $1-10$.

Rohr, D.M. \& Sмiтh, R.E. 1978. Lower Devonian Gastropoda from the Canadian Arctic Islands. Canadian Journal of Earth Sciences 15, 1228-1241. DOI 10.1139/e78-131

SANDERs, H.L. 1968. Benthic diversity: A comparative study. American Society of Naturalists 102(925), 243-282. DOI $10.1086 / 282541$

SAunders, W.B. \& WARD, P.D. 1987. Ecology, distribution and population characteristics of Nautilus, 135-162. In SAUNDERS, W.B. \& Landman, N.H. (eds) The Biology and Paleobiology of a Living Fossil. Reprinted with additions (2009). Springer, Berlin.

SCHÖNLAUB, H.P. 1996. Significant geological events in the Paleozoic record of the Southern Alps (Austrian part), 163-168. In WALLISER, O.H. (ed.) Global events and event stratigraphy in the Phanerozoic. Springer, Berlin.

Schultze, L. 1866. Monographie der Echinodermen des EiflerKalkes. Denkschrift Königlichen Akademie der Wissenschaften., mathematisch-naturwissenschaftlichen Klasse 26, $113-230$.

SCOTESE, C.R. 1997. Paleogeographic Atlas. 37 pp. PALEOMAP Progress Report 90-0497, Department of Geology, University of Texas at Arlington.

SCOTESE, C.R. \& McKerrow, W.S. 1990. Revised world maps and introduction, 1-21. In McKerrow, W.S. \& SCOTESE, C.R. (eds) Palaeozoic Palaeogeography and Biogeography. Geological Society of London Memoirs 12.

Shimizu, S. \& OвAтA, T. 1935. New genera of Gotlandian and Ordovician nautiloids. Journal of the Shanghai Science Institute, Section 2, 1-10.

Simpson, G.B. 1897. A handbook of the genera of the North American Paleozoic Bryozoa. Fourteenth Annual Report of the State Geologist, New York 1894, 407-608.

Simroth, H. 1906. Versuch einer neuen Deutung der Bellerophontiden. Sitzungsberichte der Naturforschenden Gesellschaft zu Leipzig 1905, 3-8.

Solle, G. 1952. Neue Untergattungen und Arten der BryozoenGattung Hederella und eine Hernodia im rheinischen Unterdevon. Notizblatt des Hessischen Landesamtes für Bodenforschung zu Wiesbaden 6(3), 35-55.

Solle, G. 1968. Hederelloidea (Cyclostomata) und einige ctenostome Bryozoen aus dem rheinischen Devon. Abhandlungen des Hessischen Landesamtes für Bodenforschung 54, 1-40.

SüDKAmP, W.H. \& BurRow, C.J. 2007. The acanthodian Machaeracanthus from the Lower Devonian Hunsrück Slate of the Hunsrück region (Germany). Systematic palaeontology. Paläontologische Zeitschrift 81, 97-104.

DOI 10.1007/BF02988383

Talent, J.A., Mawson, R., Andrew, A.S., Hamilton, J. \& WhiteFORD, D.J. 1993. Middle Palaeozoic extinction events: faunal and isotope data. Palaeogeography, Palaeoclimatology, Palaeoecology 104, 139-152. DOI 10.1016/0031-0182(93)90126-4

TAlENT, J.A. \& Yolkin, E.A. 1987. Transgression-regression patterns for the Devonian of Australia and southern West Siberia. Courier Forschungs-Institut Senckenberg 92, 235-249.

TAssell, C.B. 1980. Further gastropods from the Early Devonian Lilydale Limestone, Victoria. Records of the Queen Victoria Museum 69, 1-27.

Tassell, C.B. 1982. Gastropods from the Early Devonian "Receptaculites" Limestone, Taemas, New South Wales. Records of the Queen Victoria Museum 77, 1-59.

TAYLOR, P.D. \& WiLsON, M.A. 2008. Morphology and affinities of hederelloid "bryozoans", 301-309. In Hageman, S.J., Key, M.M., JR. \& Winston, J.E. (eds) Bryozoan Studies 2007: Proceedings of the $14^{\text {th }}$ International Bryozoology Conference, Boone, North Carolina, July 1-8, 2007. Virginia Museum of Natural History, Special Publication 15.

Teichert, C., Kummel, B., Sweet, W.C., Stenzel, H.B., Furnish, W.M., Glenister, B.F., Erben, H.K., Moore, R.C. \& Zeller, D.E.N. 1964. Endoceratoidea-Actinoceratoidea-Nautiloidea, K13-K124. In Moore, R.C. (ed.) Treatise on Invertebrate Paleontology, Part K, Mollusca 3, Cephalopoda. Geological Society of America and University of Kansas Pres, Boulder \& Lawrence.

Termier, G. \& Termier, H. 1950. Paléontologie Marocaine. II. Invertébrés de l'ére Primaire. Fascicule III. Mollusques. Notes et Mémoires du Service Géologique, Rabat 78, 1-246.

Toto, E.A., KaAbouben, F., Zouhri, L., Belarbi, M., Benammi, M., Hafid, M. \& Boutib, L. 2008. Geological Evolution and structural style of the Palaeozoic Tafilalt sub-basin, eastern Anti-Atlas (Morocco, North Africa). Geological Journal 43, 59-73. DOI 10.1002/gj.1098

Ubaghs, G. 1978. Part T Echinodermata 2, T403-T812. In Moore, R.C. (ed.) Treatise on Invertebrate Paleontology, Part T. Geological Society of America and University of Kansas Press 2, Lawrence.

UbAghs, G. \& BoučEK, B. 1962. Sur la présence du genre Tiaracrinus Schultze (Crinoidea) dans le Dévonien inférieur de Moravie (Tiaracrinus moravicus n. sp.). Sborník Ústředního ústavu geologického, Oddíl paleontologický 27, 41-50.

Van Geldern, R., Joachimski, M.M., Day, J., Jansen, U., AlVAREZ, F., Yolkin, E.A. \& MA, X.-P. 2006. Carbon, oxygen and strontium isotope records of Devonian brachiopod shell calcite. Palaeogeography, Palaeoclimatology, Palaeoecology 240, 47-67. DOI 10.1016/j.palaeo.2006.03.045

Verneuil, N. DE 1850. Notes sur les fossiles Dévoniens du district de Sabéro (León). Bulletin de la Société Géologique de France 7(2), 155-186.

Wachsmuth, C. \& Springer, F. 1885. Revision of the Paleocrinoidea, Part III: Discussion and classification of the brachiate crinoids, and conclusion of the generic description. Proceedings of the Academy ofNatural Sciences of Philadelphia, 223-364. 
WALKER, K.R. \& BAMBACH, R.K. 1971. The significance of fossil assemblages from fine grained sediments: Time-averaged communities. Geological Society of America Abstracts with Programs 3, 783-784.

WALLISER, O.H. 1984. Global events, event-stratigraphy and "chronostratigraphy" within the Phanerozoic, 208. In BoGDANOv, N.A. (ed.) $27^{\text {th }}$ International Geological Congress. Abstracts, section 1.

WALliser, O.H. 1985. Natural boundaries and Commission boundaries in the Devonian. Courier Forschungsinstitut Senckenberg 75, 401-408.

Webster, G.D. \& Donovan, S.K. 2012. Before the extinction Permian platyceratid gastropods attached to platycrinitid crinoids and an abnormal four-rayed Platycrinites wachsmuthi (Wanner) from West Timor. Palaeoworld 21(3-4), 153-159. DOI 10.1016/j.palwor.2012.08.001

WENDT, J. 1985. Disintegration of the continental margin of northwestern Gondwana: Late Devonian of the eastern AntiAtlas (Morocco). Geology 13, 815-818. DOI 10.1130/0091-7613(1985)13<815:DOTCMO >2.0.CO;2

WENDT, J. 1988. Facies pattern and paleogeography of the Middle and Late Devonian in the eastern Anti-Atlas (Morocco), 467-479. In McMillan, J., Embry, A.F. \& Glass, D.J. (eds) Devonian of the World, volume I. Canadian Society of Petroleum Geologists, Calgary.

Wendt, J., Aigner, T. \& Neugebauer, J. 1984. Cephalopod limestone deposition on a shallow pelagic ridge: the Tafilalt Platform (upper Devonian, eastern Anti-Atlas, Morocco). Sedimentology 31(5), 601-625. DOI 10.1111/j.1365-3091.1984.tb01226.x
Wenz, W. 1938. Gastropoda, Teil I. In Schindewolf, O.H. (ed.) Handbuch der Paläozoologie 6. 1639 pp. Borntraeger, Berlin. Westermann, G.E.G. 1999. Life of habits of nautiloids. In SAVAZZI, E. (ed.) Functional Morphology of the Invertebrate Skeleton. John Wiley \& Sons, New York.

Westermann, G.E.G. \& Tsujita, C.J. 1999. Life habits of ammonoids, 299-325. In SAvazzi, E. (ed.) Functional Morphology of the Invertebrate Skeleton. John Wiley \& Sons, New York.

WhitTaKer, R.H. 1960. Vegetation of the Siskiyou Mountains, Oregon and California. Ecological Monographs 30, 279-338. DOI $10.2307 / 1943563$

WhitTAKeR, R.H. 1972. Evolution and measurements of species diversity. Taxon 21(2-3), 213-251. DOI 10.2307/1218190

Whittington, H.B. 1988. Hypostomes of post-Cambrian trilobites. Memoirs of the New Mexico Bureau of Mines and Mineral Resources 44, 321-339.

Williams, A., Bruton, C.H.C. \& Carlson, S.J. 2000. Brachiopoda (revised), 1-920. In KAESLER, R.S. (ed.) Treatise on Invertebrate Paleontology, Part H (2-3). Geological Society of America \& University of Kansas Press, Lawrence.

Yochelson, E.L. \& LinSLEY, R.M. 1972. Opercula of two gasteropods from the Lilydale Limestone (Early Devonian) of Victoria, Australia. National Museum of Victoria, Memoir 33, $1-14$.

Zhuravleva, F.A. 1959. On the family Michelinoceratidae. Materialy k Osnovam paleontologii 3, 47-48.

ZIEGLER, B. 1972. Allgemeine Paläontologie: Einführung in die Paläontologie, Teil 1. 181 pp. Schweizerbart'sche Verlagsbuchhandlung, Stuttgart. 


\section{Appendix}

Table 1. Absolute abundances of the species found in the earliest Lochkovian to early Emsian rocks at the Jebel Ouaoufilal in the eastern Tafilalt of Morocco, and their ecological classification after Bush et al. (2007). Ecological categories: Tiering - p: pelagic, er: erect, su: surficial, smi: semi-infaunal, si: shallow infaunal, di: deep infaunal; Motility - ff: freely fast, fs: freely slow, fu: facultative unattached, fa: facultative attached, nu: non-motile and unattached, na: non-motile and attached; Feeding mechanism - s: suspension feeder, m: miner, g: grazer, pr: predators, c: coprophagous.

\begin{tabular}{|c|c|c|c|c|c|c|c|}
\hline$\frac{n}{\tilde{U}}$ & $\begin{array}{l}\frac{\infty}{0} \\
\frac{\mathscr{D}}{n}\end{array}$ & 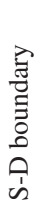 & 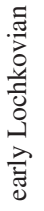 & 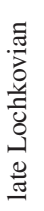 & 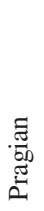 & 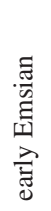 & $\begin{array}{l}\mathscr{\Xi} \\
: \\
0 \\
0 \\
0 \\
0\end{array}$ \\
\hline ?Class & $\begin{array}{l}\text { Filihernodia buccina } \\
\text { gen. et sp. nov. }\end{array}$ & 0 & 0 & 0 & 2 & & su, na, s \\
\hline Stenolaemata & $\begin{array}{l}\text { Treptosomes or } \\
\text { Cytoporates }\end{array}$ & 0 & 0 & 1 & 0 & & su, na, s \\
\hline \multirow[t]{3}{*}{ Crinoidea } & $\begin{array}{l}\text { Hexawacrinus } \\
\text { claudiakurtae gen. et } \\
\text { sp. nov. }\end{array}$ & 0 & 0 & 0 & 1 & & er, na, s \\
\hline & $\begin{array}{l}\text { Tiaracrinus cf. } \\
\text { moravicus }\end{array}$ & 0 & 0 & 0 & 1 & & er, na, s \\
\hline & Camarocrinus sp. & 65 & 0 & 0 & 0 & & $\mathrm{p}, \mathrm{nu}, \mathrm{s}$ \\
\hline Edrioasteroidea & Rhenopyrgus flos & 0 & 0 & 0 & 0 & & $\begin{array}{l}\text { smi, na, } \\
\text { s }\end{array}$ \\
\hline \multirow[t]{15}{*}{ Anthozoa } & Favositidae 1 & 0 & 0 & 0 & 19 & & su, na, s \\
\hline & $\begin{array}{l}\text { Cleistopora } \mathrm{cf} . \\
\text { geometrica }\end{array}$ & 0 & 0 & 0 & 4 & & su, na, s \\
\hline & Proclevia sp. & 0 & 0 & 0 & 1 & & su, na, s \\
\hline & Tabulata 1 & 0 & 0 & 0 & 3 & & su, na, s \\
\hline & Tabulata 2 & 0 & 0 & 0 & 2 & & su, na, s \\
\hline & aff. Striatopora sp. & 0 & 0 & 0 & 7 & & su, na, s \\
\hline & Auloporidae 1 & 0 & 3 & 0 & 0 & & su, na, s \\
\hline & Aulopora sp. & 0 & 0 & 0 & 1 & & su, na, s \\
\hline & Rugosa 1 & 0 & 0 & 0 & 1 & & su, na, pr \\
\hline & Rugosa 2 & 0 & 0 & 0 & 3 & & $\mathrm{su}, \mathrm{na}, \mathrm{pr}$ \\
\hline & Rugosa 3 & 0 & 0 & 0 & 2 & & su, na, pr \\
\hline & Rugosa 4 & 0 & 0 & 0 & 17 & & su, na, pr \\
\hline & Rugosa 5 & 0 & 0 & 0 & 6 & & su, na, pr \\
\hline & Rugosa 6 & 0 & 0 & 0 & 3 & & su, na, pr \\
\hline & Rugosa 7 & 0 & 0 & 0 & 1 & & su, na, pr \\
\hline \multirow[t]{6}{*}{ Trilobita } & Reedops bronni & 0 & 0 & 0 & 1 & & su, ff, pr \\
\hline & $\begin{array}{l}\text { Reedops cf. } \\
\text { cephalotes } \\
\text { hamalagdadianus }\end{array}$ & 0 & 0 & 0 & 7 & & su, ff, pr \\
\hline & Pseudocryphaeus sp. & 0 & 0 & 0 & 1 & & su, ff, pr \\
\hline & Pilletina zguidensis & 0 & 0 & 0 & 0 & & su, ff, pr \\
\hline & $\begin{array}{l}\text { Metacanthina } \\
\text { wallacei }\end{array}$ & 0 & 0 & 0 & 0 & & $\mathrm{su}, \mathrm{ff}, \mathrm{pr}$ \\
\hline & $\begin{array}{l}\text { Odontochile cf. } \\
\text { hausmanni }\end{array}$ & 0 & 0 & 0 & 1 & & su, ff, pr \\
\hline
\end{tabular}

\begin{tabular}{|c|c|c|c|c|c|c|c|}
\hline \multirow[t]{5}{*}{$\frac{\mathscr{2}}{\tilde{U}}$} & 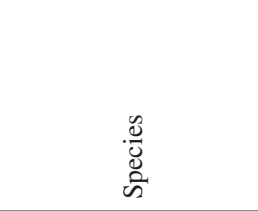 & 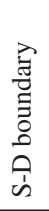 & 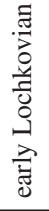 & 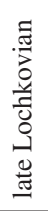 & 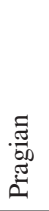 & 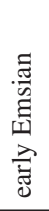 & $\begin{array}{l}\stackrel{0}{=} \\
\ddot{0} \\
0 \\
0 \\
0 \\
\Sigma\end{array}$ \\
\hline & $\begin{array}{l}\text { Cheirurus } \\
\text { (Crotalocephalus) sp. }\end{array}$ & 0 & 0 & 0 & 2 & & su, ff, pr \\
\hline & Hollardops sp. & 0 & 0 & 0 & 1 & & su, ff, pr \\
\hline & $\begin{array}{l}\text { Paralejurus } \\
\text { elayounensis }\end{array}$ & 0 & 0 & 0 & 2 & & su, ff, pr \\
\hline & $\begin{array}{l}\text { Paralejurus } \\
\text { campanifer }\end{array}$ & 0 & 0 & 0 & 0 & & su, ff, pr \\
\hline Malacostraca & Nahecaris jannae & 0 & 0 & 0 & 0 & & $\mathrm{su}, \mathrm{ff}, \mathrm{s}$ \\
\hline \multirow[t]{8}{*}{ Rhynchonellata } & Desquamatia sp. & 0 & 0 & 0 & 4 & & su, na, s \\
\hline & ?Aulacella eifeliensis & 0 & 0 & 0 & 1 & & su, na, s \\
\hline & $\begin{array}{l}\text { aff. } \\
\text { Eoglossinotoechia } \\
\text { sp. }\end{array}$ & 0 & 0 & 0 & 1 & & su, na, s \\
\hline & $\begin{array}{l}\text { Brachiopoda gen. et } \\
\text { sp. indet. }\end{array}$ & 0 & 0 & 0 & 6 & 0 & su, na, s \\
\hline & ?Protathyris $\mathrm{sp}$. & 0 & 0 & 2 & 9 & & su, na, s \\
\hline & Cingulodermis sp. & 0 & 0 & 0 & 12 & & su, na, s \\
\hline & $\begin{array}{l}\text { Arduspirifer } \\
\text { arduennensis }\end{array}$ & 0 & 0 & 2 & 0 & & su, na, s \\
\hline & $\begin{array}{l}\text { Quadrithyris } \\
\text { termierae }\end{array}$ & 0 & 0 & 0 & 0 & & su, na, s \\
\hline Strophomenata & ?Dagnachonetes sp. & 0 & 0 & 0 & 1 & & $\mathrm{su}, \mathrm{nu}, \mathrm{s}$ \\
\hline \multirow[t]{19}{*}{ Bivalvia } & Bivalvia ind. 1 & 0 & 0 & 10 & 0 & 0 & \\
\hline & Panenka humilis & 0 & 0 & 5 & 1 & & si, fu, m \\
\hline & Panenka hollardi & 0 & 0 & 0 & 3 & & si, fu, m \\
\hline & Panenka princeps & 0 & 1 & 0 & 0 & & si, fu, m \\
\hline & Panenka sp. 1 & 0 & 1 & 0 & 0 & & si, fu, m \\
\hline & Panenka obsequens & 3 & 0 & 0 & 0 & & si, fu, m \\
\hline & Neklania cf. resecta & 0 & 1 & 0 & 0 & & si, fu, m \\
\hline & Neklania cf. obtusa & 0 & 0 & 1 & 0 & & $\mathrm{si}, \mathrm{fu}, \mathrm{m}$ \\
\hline & Jahnia sp. & 0 & 0 & 1 & 0 & & $\mathrm{si}, \mathrm{fu}, \mathrm{m}$ \\
\hline & $\begin{array}{l}\text { Jahnia aff. } \\
\text { conscripta }\end{array}$ & 0 & 5 & 0 & 0 & & $\mathrm{si}, \mathrm{fu}, \mathrm{m}$ \\
\hline & $\begin{array}{l}\text { Patrocardia evolvens } \\
\text { evolvens }\end{array}$ & 0 & 0 & 0 & 0 & & su, fa, s \\
\hline & $\begin{array}{l}\text { Patrocardia } \\
\text { excellens } \mathrm{sp} .\end{array}$ & 0 & 0 & 0 & 0 & & su, fa, s \\
\hline & Patrocardia tarda & 0 & 0 & 2 & 2 & & $\mathrm{su}, \mathrm{fa}, \mathrm{s}$ \\
\hline & $\begin{array}{l}\text { Mytilarca } \mathrm{cf} . \\
\text { chemungensis }\end{array}$ & 0 & 0 & 0 & 0 & & su, fa, s \\
\hline & Mytilarca sp. & 0 & 0 & 2 & 0 & & su, fa, s \\
\hline & $\begin{array}{l}\text { Actinopteria } \mathrm{cf} . \\
\text { decussata }\end{array}$ & 0 & 0 & 11 & 0 & & smi, fa, s \\
\hline & Grammysioidea sp. & 0 & 0 & 0 & 0 & & si, fa, s \\
\hline & $\begin{array}{l}\text { Nuculoidea } \\
\text { grandaeva }\end{array}$ & 0 & 0 & 0 & 1 & & $\mathrm{si}, \mathrm{fu}, \mathrm{m}$ \\
\hline & Eописиloma babini & 0 & 0 & 0 & 0 & & si, fu, m \\
\hline
\end{tabular}




\begin{tabular}{|c|c|c|c|c|c|c|}
\hline$\frac{\tilde{w}}{\tilde{U}}$ & $\begin{array}{l}\frac{\infty}{\tilde{D}_{0}} \\
\frac{0}{n}\end{array}$ & 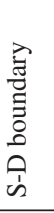 & 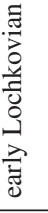 & 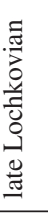 & 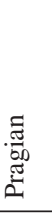 & 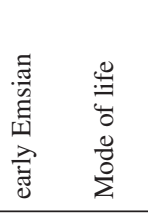 \\
\hline & $\begin{array}{l}\text { Palaeoneilo } \\
\text { emarginata }\end{array}$ & 0 & 0 & 0 & 2 & $59 \mathrm{si}, \mathrm{fu}, \mathrm{m}$ \\
\hline & Nuculites celticus & 0 & 0 & 0 & 0 & $5 \mathrm{si}, \mathrm{fu}, \mathrm{m}$ \\
\hline & Cucullella triquetra & 0 & 0 & 0 & 0 & $52 \mathrm{si}, \mathrm{fu}, \mathrm{m}$ \\
\hline & Phestia rostellata & 0 & 0 & 0 & 0 & $149 \mathrm{di}, \mathrm{fu}, \mathrm{m}$ \\
\hline Rostroconchia & $\begin{array}{l}\text { Bohemicardia } \\
\text { bohemicus }\end{array}$ & 0 & 0 & 0 & 1 & $\begin{array}{l}0 \mathrm{smi}, \mathrm{nu}, \\
\mathrm{s}\end{array}$ \\
\hline Hyolitha & Orthotheca sp. & 0 & 0 & 0 & 3 & $66 \mathrm{su}, \mathrm{nu}, \mathrm{s}$ \\
\hline \multirow[t]{2}{*}{ Machaeridia } & Machaeridia 1 & 0 & 0 & 0 & 1 & $0 \mathrm{si}, \mathrm{fs}, \mathrm{m}$ \\
\hline & Lepidocoleus rugatus & 0 & 0 & 0 & 0 & $5 \mathrm{si}, \mathrm{fs}, \mathrm{m}$ \\
\hline \multirow[t]{3}{*}{ Amphigastropoda } & $\begin{array}{l}\text { aff. Coelocyclus sp. } \\
\text { nov. }\end{array}$ & 0 & 0 & 0 & 1 & $0 \mathrm{su}, \mathrm{fs}, \mathrm{g}$ \\
\hline & Sinuitina sp. & 0 & 0 & 0 & 0 & $5 \mathrm{su}, \mathrm{fs}, \mathrm{g}$ \\
\hline & Crenistriella sp. & 0 & 0 & 0 & 0 & $8 \mathrm{su}, \mathrm{fs}, \mathrm{g}$ \\
\hline \multirow[t]{24}{*}{ Gastropoda } & Gastropoda ind. 1 & 0 & 0 & 20 & 0 & $0 \mathrm{su}, \mathrm{fs}, \mathrm{g}$ \\
\hline & Gastropoda ind. 2 & 0 & 0 & 0 & 4 & $0 \mathrm{su}, \mathrm{fs}, \mathrm{g}$ \\
\hline & Gastropoda ind. 3 & 0 & 0 & 0 & 2 & $5 \mathrm{su}, \mathrm{fs}, \mathrm{g}$ \\
\hline & Gastropoda ind. 4 & 0 & 0 & 3 & 0 & 0 su, fs, g \\
\hline & Gastropoda ind. 5 & 0 & 0 & 4 & 0 & $0 \mathrm{su}, \mathrm{fs}, \mathrm{g}$ \\
\hline & Gastropoda ind. 6 & 0 & 0 & 34 & 0 & $0 \mathrm{su}, \mathrm{fs}, \mathrm{g}$ \\
\hline & Spirina $\mathrm{sp}$. & 0 & 0 & 0 & 1 & $0 \mathrm{su}, \mathrm{fs}, \mathrm{g}$ \\
\hline & $\begin{array}{l}\text { Oriomphalus } \\
\text { multiornatus gen. et } \\
\text { sp. nov. }\end{array}$ & 0 & 0 & 0 & 7 & $0 \mathrm{su}, \mathrm{fs}, \mathrm{g}$ \\
\hline & $\begin{array}{l}\text { Australonema sp. } \\
\text { nov. }\end{array}$ & 0 & 0 & 0 & 2 & $0 \mathrm{su}, \mathrm{fs}, \mathrm{g}$ \\
\hline & Eotomarioidea ind. 1 & 0 & 0 & 0 & 1 & $0 \mathrm{su}, \mathrm{fs}, \mathrm{g}$ \\
\hline & Eotomarioidea ind. 2 & 0 & 0 & 0 & 1 & $0 \mathrm{su}, \mathrm{fs}, \mathrm{g}$ \\
\hline & Paraoehlertia sp. & 0 & 0 & 0 & 1 & $0 \mathrm{su}, \mathrm{fs}, \mathrm{g}$ \\
\hline & Umbotropis sp. & 0 & 0 & 0 & 2 & $0 \mathrm{su}, \mathrm{fs}, \mathrm{g}$ \\
\hline & $\begin{array}{l}\text { Eohormotomina } \\
\text { restisevoluta gen. et } \\
\text { sp. nov. }\end{array}$ & 0 & 0 & 0 & 2 & $0 \mathrm{su}, \mathrm{fs}, \mathrm{g}$ \\
\hline & Rihamphalus gracilis & 0 & 0 & 0 & 5 & 0 su, fs, g \\
\hline & aff. Tychobrahea sp. & 0 & 0 & 0 & 1 & $0 \mathrm{su}, \mathrm{fs}, \mathrm{g}$ \\
\hline & $\begin{array}{l}\text { Loxonematoidea } \\
\text { ind. } 1\end{array}$ & 0 & 0 & 0 & 7 & $0 \mathrm{su}, \mathrm{fs}, \mathrm{g}$ \\
\hline & $\begin{array}{l}\text { Loxonematoidea } \\
\text { ind. } 2\end{array}$ & 0 & 0 & 0 & 3 & $0 \mathrm{su}, \mathrm{fs}, \mathrm{g}$ \\
\hline & $\begin{array}{l}\text { Palaeozygopleura sp. } \\
\text { nov }\end{array}$ & 0 & 0 & 1 & 14 & $0 \mathrm{su}, \mathrm{fs}, \mathrm{g}$ \\
\hline & Palaeozygopleura sp. & 0 & 0 & 0 & 0 & $34 \mathrm{su}, \mathrm{fs}, \mathrm{g}$ \\
\hline & $\begin{array}{l}\text { Pleurotomarioidea } \\
\text { ind., new genus? }\end{array}$ & 0 & 0 & 0 & 2 & $0 \mathrm{su}, \mathrm{fs}, \mathrm{g}$ \\
\hline & Lukesispira pulchra & 0 & 0 & 0 & 0 & 9 su, fs, g \\
\hline & Planitrochus tardus & 0 & 0 & 0 & 0 & $12 \mathrm{su}, \mathrm{fs}, \mathrm{g}$ \\
\hline & Platyceratidae ind. 1 & 7 & 0 & 0 & 0 & $0 \mathrm{p}, \mathrm{fu}, \mathrm{c}$ \\
\hline
\end{tabular}

\begin{tabular}{|c|c|c|c|c|c|c|}
\hline $\begin{array}{l}\frac{w}{0} \\
\frac{\tilde{\sigma}}{U}\end{array}$ & 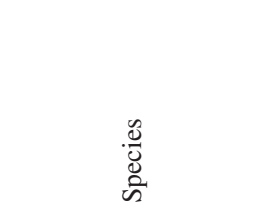 & 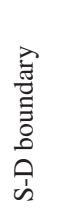 & 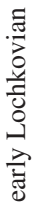 & 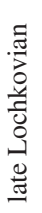 & . & 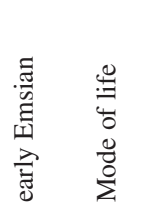 \\
\hline & Orthonychia sp. & 0 & 0 & 0 & 1 & $0 \mathrm{su}, \mathrm{fs}, \mathrm{c}$ \\
\hline \multirow[t]{31}{*}{ Cephalopoda } & Orthocerida ind. 1 & 21 & 0 & 0 & 0 & $0 \mathrm{p}, \mathrm{fs}, \mathrm{pr}$ \\
\hline & Orthocerida ind. 2 & 0 & 0 & 0 & 4 & $0 \mathrm{p}, \mathrm{fs}, \mathrm{pr}$ \\
\hline & Orthocerida ind. 3 & 0 & 0 & 0 & 1 & $0 \mathrm{p}, \mathrm{fs}, \mathrm{pr}$ \\
\hline & Orthocerida ind. 4 & 0 & 0 & 0 & 1 & $0 \mathrm{p}, \mathrm{fs}, \mathrm{pr}$ \\
\hline & Orthocerida ind. 5 & 0 & 0 & 1 & 0 & $0 \mathrm{p}, \mathrm{fs}, \mathrm{pr}$ \\
\hline & Endoplectoceras sp. & 0 & 0 & 0 & 1 & $0 \mathrm{p}, \mathrm{fs}, \mathrm{pr}$ \\
\hline & $\begin{array}{l}\text { Pseudendoplectoceras } \\
\text { lahcani }\end{array}$ & 0 & 0 & 1 & 1 & $0 \mathrm{p}, \mathrm{fs}, \mathrm{pr}$ \\
\hline & Bohemojovellania sp. & 0 & 0 & 3 & 0 & $0 \mathrm{p}, \mathrm{fs}, \mathrm{pr}$ \\
\hline & Tafilaltoceras adgoi & 0 & 0 & 0 & 1 & $0 \mathrm{p}, \mathrm{fs}, \mathrm{pr}$ \\
\hline & $\begin{array}{l}\text { Pseudorthoceratidae } \\
\text { ind. } 1\end{array}$ & 0 & 0 & 1 & 0 & $0 \mathrm{p}, \mathrm{fs}, \mathrm{pr}$ \\
\hline & $\begin{array}{l}\text { Geidoloceras } \\
\text { ouaoufilalense }\end{array}$ & 0 & 0 & 0 & 24 & $0 \mathrm{p}, \mathrm{fs}, \mathrm{pr}$ \\
\hline & $\begin{array}{l}\text { Subdoloceras } \\
\text { atrouzense }\end{array}$ & 0 & 0 & 0 & 46 & $0 \mathrm{p}, \mathrm{fs}, \mathrm{pr}$ \\
\hline & $\begin{array}{l}\text { Subdoloceras } \\
\text { engeseri }\end{array}$ & 0 & 0 & 0 & 40 & $0 \mathrm{p}, \mathrm{fs}, \mathrm{pr}$ \\
\hline & $\begin{array}{l}\text { Spyroceras } \\
\text { cyrtopatronus }\end{array}$ & 0 & 0 & 0 & 6 & $0 \mathrm{p}, \mathrm{fs}, \mathrm{pr}$ \\
\hline & $\begin{array}{l}\text { Spyroceras } \\
\text { latepatronus }\end{array}$ & 0 & 0 & 0 & 1 & $0 \mathrm{p}, \mathrm{fs}, \mathrm{pr}$ \\
\hline & Spyroceras patronus & 0 & 0 & 0 & 3 & $0 \mathrm{p}, \mathrm{fs}, \mathrm{pr}$ \\
\hline & Spyroceras sp. & 0 & 0 & 0 & 0 & $9 \mathrm{p}, \mathrm{fs}, \mathrm{pr}$ \\
\hline & $\begin{array}{l}\text { Cancellspyroceras } \\
\text { loricatum }\end{array}$ & 0 & 0 & 0 & 6 & $0 \mathrm{p}, \mathrm{fs}, \mathrm{pr}$ \\
\hline & $\begin{array}{l}\text { Arthrophyllum } \\
\text { vermiculare }\end{array}$ & 0 & 0 & 0 & 63 & $13 \mathrm{p}, \mathrm{fs}, \mathrm{pr}$ \\
\hline & $\begin{array}{l}\text { Murchisoniceras } \\
\text { murchisoni }\end{array}$ & 0 & 0 & 0 & 0 & $96 \mathrm{p}, \mathrm{fs}, \mathrm{pr}$ \\
\hline & $\begin{array}{l}\text { Infundibuloceras } \\
\text { brevimira }\end{array}$ & 0 & 0 & 0 & 0 & $18 \mathrm{p}, \mathrm{fs}, \mathrm{pr}$ \\
\hline & Neocycloceras sp. & 0 & 0 & 0 & 0 & $1 \mathrm{p}, \mathrm{fs}, \mathrm{pr}$ \\
\hline & Michelinoceras sp. & 0 & 0 & 0 & 1 & $0 \mathrm{p}, \mathrm{fs}, \mathrm{pr}$ \\
\hline & $\begin{array}{l}\text { Orthocycloceras } \\
\text { tafilaltense }\end{array}$ & 0 & 0 & 0 & 3 & $0 \mathrm{p}, \mathrm{fs}, \mathrm{pr}$ \\
\hline & Orthocycloceras sp. & 0 & 0 & 0 & 0 & $26 \mathrm{p}, \mathrm{fs}, \mathrm{pr}$ \\
\hline & $\begin{array}{l}\text { Tenuitheoceras } \\
\text { secretum gen. et sp. } \\
\text { nov. }\end{array}$ & 0 & 0 & 0 & 1 & $0 \mathrm{p}, \mathrm{fs}, \mathrm{pr}$ \\
\hline & Tibichoanoceras sp. & 0 & 0 & 0 & 1 & $0 \mathrm{p}, \mathrm{fs}, \mathrm{pr}$ \\
\hline & $\begin{array}{l}\text { Arionoceras } \\
\text { kennethdebaetsi sp. } \\
\text { nov. }\end{array}$ & 0 & 0 & 0 & 1 & $0 \mathrm{p}, \mathrm{fs}, \mathrm{pr}$ \\
\hline & Adiagoceras sp. & 0 & 0 & 0 & 2 & $0 \mathrm{p}, \mathrm{fs}, \mathrm{pr}$ \\
\hline & Anaspyroceras sp. & 0 & 0 & 0 & 1 & $0 \mathrm{p}, \mathrm{fs}, \mathrm{pr}$ \\
\hline & Harrisoceras sp. & 0 & 0 & 0 & 1 & $0 \mathrm{p}, \mathrm{fs}, \mathrm{pr}$ \\
\hline
\end{tabular}




\begin{tabular}{|c|c|c|c|c|c|c|c|}
\hline$\frac{n}{\tilde{U}}$ & 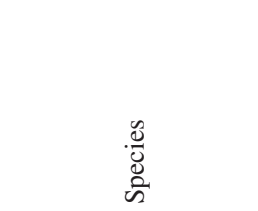 & 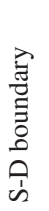 & 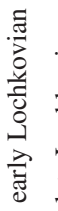 & 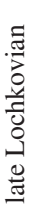 & 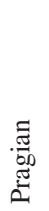 & 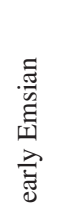 & 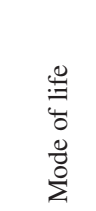 \\
\hline & $\begin{array}{l}\text { Angeisonoceras } \\
\text { reteornatum }\end{array}$ & 0 & 0 & 0 & 11 & & $\mathrm{p}, \mathrm{fs}, \mathrm{pr}$ \\
\hline & $\begin{array}{l}\text { Temperoceras } \\
\text { aequinudum }\end{array}$ & 0 & 0 & 0 & 3 & & $\mathrm{p}, \mathrm{fs}, \mathrm{pr}$ \\
\hline & Temperoceras sp. 1 & 0 & \multicolumn{2}{|c|}{0122} & 0 & \multicolumn{2}{|c|}{$0 \mathrm{p}, \mathrm{fs}, \mathrm{pr}$} \\
\hline & Temperoceras sp. 2 & 0 & 0 & 0 & 0 & \multicolumn{2}{|c|}{$36 \mathrm{p}, \mathrm{fs}, \mathrm{pr}$} \\
\hline & $\begin{array}{l}\text { Temperoceras } \\
\text { ludense }\end{array}$ & 0 & 0 & 0 & 10 & \multicolumn{2}{|c|}{$0 \mathrm{p}, \mathrm{fs}, \mathrm{pr}$} \\
\hline & Sphaerorthoceratidae & 0 & 0 & 0 & 1 & \multicolumn{2}{|c|}{$0 \mathrm{p}, \mathrm{fs}, \mathrm{pr}$} \\
\hline & $\begin{array}{l}\text { Plagiostomoceras } \\
\text { culter }\end{array}$ & & 121 & 0 & 0 & \multicolumn{2}{|c|}{$0 \mathrm{p}, \mathrm{fs}, \mathrm{pr}$} \\
\hline & $\begin{array}{l}\text { Plagiostomoceras } \\
\text { hassichebbiense }\end{array}$ & 0 & 0 & 0 & 0 & \multicolumn{2}{|c|}{$7 \mathrm{p}, \mathrm{fs}, \mathrm{pr}$} \\
\hline & Plagiostomoceras sp. & 0 & 0 & 0 & 2 & \multicolumn{2}{|c|}{$0 \mathrm{p}, \mathrm{fs}, \mathrm{pr}$} \\
\hline & $\begin{array}{l}\text { Hemicosmorthoceras } \\
\text { sp. }\end{array}$ & 0 & 0 & 0 & 1 & \multicolumn{2}{|c|}{$0 \mathrm{p}, \mathrm{fs}, \mathrm{pr}$} \\
\hline & Bactritidae ind. & 0 & 0 & 0 & 1 & \multicolumn{2}{|c|}{$0 \mathrm{p}, \mathrm{fs}, \mathrm{pr}$} \\
\hline & $\begin{array}{l}\text { Devonobactrites } \\
\text { obliquiseptatus }\end{array}$ & 0 & 0 & 0 & & \multicolumn{2}{|c|}{$1604 \mathrm{p}, \mathrm{fs}, \mathrm{pr}$} \\
\hline Placodermi & $\begin{array}{l}\text { Brachythoracid } \\
\text { placoderm }\end{array}$ & 0 & 0 & 0 & 0 & \multicolumn{2}{|c|}{$5 \mathrm{p}, \mathrm{ff}, \mathrm{pr}$} \\
\hline Acanthodii & $\begin{array}{l}\text { Machaeracanthus } \mathrm{cf} . \\
\text { peracutus }\end{array}$ & 0 & 00 & & 0 & \multicolumn{2}{|c|}{$18 \mathrm{p}, \mathrm{ff}, \mathrm{pr}$} \\
\hline
\end{tabular}

